\title{
The Chemistry of Boryllithium: Synthesis, Structure, and Reactivity
}

\author{
Yasutomo Segawa, Yuta Suzuki, Makoto Yamashita*, and Kyoko Nozaki* \\ *To whom correspondence should be addressed. \\ E-mail: makotoy@chembio.t.u-tokyo.ac.jp;nozaki@chembio.t.u-tokyo.ac.jp
}

\section{Experimental Section \\ General}

All manipulations were carried out in the argon-filled glove box (Miwa MFG) unless otherwise noted. The ${ }^{1} \mathrm{H},{ }^{1} \mathrm{H}\left\{{ }^{11} \mathrm{~B}\right\},{ }^{2} \mathrm{H},{ }^{7} \mathrm{Li}\left\{{ }^{1} \mathrm{H}\right\},{ }^{11} \mathrm{~B},{ }^{11} \mathrm{~B}\left\{{ }^{1} \mathrm{H}\right\},{ }^{13} \mathrm{C}\left\{{ }^{1} \mathrm{H}\right\}$, and ${ }^{19} \mathrm{~F}$ NMR spectra were recorded on $500 \mathrm{MHz}$ spectrometers with residual protiated solvent for ${ }^{1} \mathrm{H}$ and ${ }^{1} \mathrm{H}\left\{{ }^{11} \mathrm{~B}\right\}$, deuterated solvent for ${ }^{2} \mathrm{H}$ and ${ }^{13} \mathrm{C}\left\{{ }^{1} \mathrm{H}\right\}$, an external $\mathrm{LiBr}$ in $\mathrm{D}_{2} \mathrm{O}$ for ${ }^{7} \mathrm{Li}\left\{{ }^{1} \mathrm{H}\right\}$, an external $\mathrm{BF}_{3} \cdot \mathrm{OEt}_{2}$ for ${ }^{11} \mathrm{~B}$ and ${ }^{11} \mathrm{~B}\left\{{ }^{1} \mathrm{H}\right\}$, and an external $\mathrm{CFCl}_{3}$ for ${ }^{19} \mathrm{~F}\left\{{ }^{1} \mathrm{H}\right\}$ used as reference. 38a- $\boldsymbol{d}_{\mathbf{1}}, \mathbf{5 5}, \mathbf{5 6}$, and $\mathbf{5 9}$ were purified by using a recycling preparative HPLC (LC928, Japan Analytical Industries, $60 \mathrm{~cm} \times 20 \phi$ Jaigel- $1 \mathrm{H}$ and $2 \mathrm{H}, \mathrm{CHCl}_{3}$ eluent). Mass spectra were recorded on a JEOL JMS-SX 102 spectrometer using PEG calibration and NBA matrix solvent. Melting points were measured on a Yanagimoto micro melting point apparatus MP-500D and MPA100 Optimelt Automated Melting Point System and are uncorrected. Ether, THF and hexane were purified by passing through a solvent purification system (Grass Contour). Dimethoxyethane (DME) was distilled from sodium/benzophenone. All these solvents were further dried by stirring with $\mathrm{Na} / \mathrm{K}$ alloy at room temperature in the glovebox prior to use unless otherwise noted. Lithium dispersion (purchased from Kanto Chemical Co., Inc., containing 1\% sodium) was washed with hexane before the use to make a lithium powder. Carbon dioxide $(>99.990 \mathrm{vol} \%$, containing $<0.005$ vol\% water) was obtained from Showa Tansan Co., Ltd. $\mathrm{PhCH}_{2} \mathrm{~K},{ }^{1} \mathbf{3 4 f}{ }^{2}$ $\mathbf{3 4 g}^{3} 36,{ }^{4} 39,{ }^{4} \mathbf{4 0},{ }^{5} \mathbf{4 1},{ }^{4} \mathbf{4 2},{ }^{4}$ and $\mathbf{4 8}^{6}$ were synthesized according to literature procedures.

\section{Synthesis of 34a-Br (Method A)}

A suspension of $36(7.20 \mathrm{~g}, 19.0 \mathrm{mmol})$ and $\mathrm{Mg}(2.00 \mathrm{~g}, 82.0 \mathrm{mmol})$ in ether $(100 \mathrm{~mL})$ was heated to reflux until the color of the solution became red under argon atmosphere. After cooling the solution to $0{ }^{\circ} \mathrm{C}$, a solution of $\mathrm{BBr}_{3}$ in hexane $(1.00 \mathrm{M} ; 20.0 \mathrm{~mL}, 20.0$ mmol) was added to the mixture at $0{ }^{\circ} \mathrm{C}$. The resulting solution was stirred for $12 \mathrm{~h}$ at $0{ }^{\circ} \mathrm{C}$ to afford a cream-green suspension. After solvents were evaporated under reduced pressure, hexane $(50 \mathrm{~mL})$ was added to a residue. The resulting suspension was filtered through Celite pad to remove magnesium salt under argon, and the insoluble salts were washed with hexane. Volatiles were removed from the filtrate to give a white solid $(5.00 \mathrm{~g}, 56.0 \%)$. An analytically pure sample was obtained from the recrystallization from hexane. ${ }^{1} \mathrm{H}$ NMR 
$\left(\mathrm{C}_{6} \mathrm{D}_{6}, 500 \mathrm{MHz}\right) \delta 1.20(\mathrm{~d}, J=7 \mathrm{~Hz}, 12 \mathrm{H}), 1.31(\mathrm{~d}, J=7 \mathrm{~Hz}, 12 \mathrm{H}), 3.16(\mathrm{sep}, J=7 \mathrm{~Hz}$, $4 \mathrm{H}), 6.12(\mathrm{~s}, 2 \mathrm{H}), 7.14(\mathrm{~d}, J=9 \mathrm{~Hz}, 4 \mathrm{H}), 7.22(\mathrm{dd}, J=8 \mathrm{~Hz}, 9 \mathrm{~Hz}, 2 \mathrm{H}) ;{ }^{13} \mathrm{C} \mathrm{NMR}\left(\mathrm{C}_{6} \mathrm{D}_{6}\right.$, $125 \mathrm{MHz}) \delta 24.2\left(\mathrm{CH}_{3}\right), 24.5\left(\mathrm{CH}_{3}\right), 28.9(\mathrm{CH}), 120.2(\mathrm{CH}), 123.9(\mathrm{CH}), 128.5(\mathrm{CH})$, $137.5\left(4^{\circ}\right), 146.4\left(4^{\circ}\right) ;{ }^{11} \mathrm{~B}$ NMR $\left(\mathrm{C}_{6} \mathrm{D}_{6}, 160 \mathrm{MHz}\right) \delta 20.2$ (brs, $\left.h_{1 / 2}=152 \mathrm{~Hz}\right) ; \mathrm{mp}$ : 182.0-187.0 ${ }^{\circ} \mathrm{C}$ (dec.); HRMS-FAB $(\mathrm{m} / z)$ : $[\mathrm{M}]^{+}$calcd for $\mathrm{C}_{26} \mathrm{H}_{36} \mathrm{BBrN}_{2}, 466.2155$, 468.2135; found, 466.2156, 468.2156.

\section{Synthesis of 34a-Br (Method B)}

A suspension of 36 (34.6 g, $91.9 \mathrm{mmol})$ and lithium granule $(1.89 \mathrm{~g}, 272 \mathrm{mmol})$ in ether $(400 \mathrm{~mL})$ was stirred at room temperature for 2 days under argon atmosphere to afford a dark yellow suspension. After removing excess lithium by filtration, $\mathrm{NEt}_{3} \mathrm{HCl}(26.2 \mathrm{~g}, 190$ $\mathrm{mmol}$ ) was added to the filtrate, and the resulting white suspension was stirred at room temperature for $1 \mathrm{~h}$. The suspension was filtered through Celite pad to remove excess $\mathrm{NEt}_{3} \mathrm{HCl}$, the solvent and $\mathrm{NEt}_{3}$ were evaporated and the resulting residue was dissolved in $\mathrm{CH}_{2} \mathrm{Cl}_{2}(100 \mathrm{ml}) . \mathrm{BBr}_{3}$ solution $\left(1 \mathrm{M} \mathrm{CH}_{2} \mathrm{Cl}_{2}, 100 \mathrm{~mL}, 100 \mathrm{mmol}\right)$ was added dropwise to the resulting solution at $0{ }^{\circ} \mathrm{C}$ and stirred at room temperature for $12 \mathrm{~h}$. Reaction was quenched with ${ }^{i} \operatorname{Pr}_{2} \operatorname{EtN}$ (28.2 g, $218 \mathrm{mmol}$ ), and the solvents and excess ${ }^{i} \operatorname{Pr}_{2} \operatorname{EtN}$ were removed at reduced pressure. Hexane $(400 \mathrm{~mL})$ was added to the resulting residue, the suspension was filtered through Celite pad and the insoluble solts were washed with hexane. After volatiles ware removed from the filtrate, recrystallization from hexane at $-45{ }^{\circ} \mathrm{C}$ yielded a colorless crystal $(32.9 \mathrm{~g}, 77 \%)$.

\section{Synthesis of $34 \mathrm{a}-\mathrm{Cl}^{7}$}

A suspension of $36(891 \mathrm{mg}, 2.37 \mathrm{mmol})$ and lithium granule $(49.2 \mathrm{mg}, 7.09 \mathrm{mmol})$ in ether $(30 \mathrm{~mL})$ was stirred at room temperature for 1 days under argon atmosphere to afford a dark yellow suspension. After removing excess lithium by filtration, $\mathrm{NEt}_{3} \mathrm{HCl}(814 \mathrm{mg}$, $5.91 \mathrm{mmol}$ ) was added to the filtrate, and the resulting white suspension was stirred at room temperature for $1 \mathrm{~h}$. The suspension was filtered through Celite pad to remove excess $\mathrm{NEt}_{3} \mathrm{HCl}$, the solvent and $\mathrm{NEt}_{3}$ were evaporated and the resulting residue was dissolved in $\mathrm{CH}_{2} \mathrm{Cl}_{2}(50 \mathrm{ml}) . \mathrm{BCl}_{3}$ solution $(1 \mathrm{M}$ heptane, $2.48 \mathrm{~mL}, 2.48 \mathrm{mmol})$ was added dropwise to the resulting solution at $0{ }^{\circ} \mathrm{C}$ and stirred at room temperature for $12 \mathrm{~h}$. Reaction was quenched with ${ }^{i} \operatorname{Pr}_{2} \operatorname{EtN}$ (764 mg, $5.92 \mathrm{mmol}$ ), and the solvents and excess ${ }^{i} \operatorname{Pr}_{2} \operatorname{EtN}$ were removed at reduced pressure. Hexane $(100 \mathrm{~mL})$ was added to the resulting residue, the suspension was filtered through Celite pad and the insoluble solts were washed with hexane. After reducing volatiles, the resulting solution was charged on the top of a silica gel column (hexane) and the product was separated to give a white solid. $(324 \mathrm{~g}, 32 \%){ }^{1} \mathrm{H} \mathrm{NMR}\left(\mathrm{C}_{6} \mathrm{D}_{6}\right)$ $\delta: 1.20(\mathrm{~d}, J=7 \mathrm{~Hz}, 12 \mathrm{H}), 1.30(\mathrm{~d}, J=7 \mathrm{~Hz}, 12 \mathrm{H}), 3.18(\mathrm{sep}, J=7 \mathrm{~Hz}, 4 \mathrm{H}), 6.05(\mathrm{~s}, 2 \mathrm{H})$, $7.14(\mathrm{~d}, J=8 \mathrm{~Hz}, 4 \mathrm{H}), 7.22(\mathrm{dd}, J=8,7 \mathrm{~Hz}, 2 \mathrm{H}) ;{ }^{13} \mathrm{C}$ NMR $\left(\mathrm{C}_{6} \mathrm{D}_{6}, 125 \mathrm{MHz}\right) \delta 24.2$ $\left(\mathrm{CH}_{3}\right), 24.3\left(\mathrm{CH}_{3}\right), 28.9(\mathrm{CH}), 119.2(\mathrm{CH}), 123.8(\mathrm{CH}), 128.4(\mathrm{CH}), 137.1\left(4^{\circ}\right), 146.5\left(4^{\circ}\right)$; ${ }^{11} \mathrm{~B}$ NMR $\left(\mathrm{C}_{6} \mathrm{D}_{6}, 160 \mathrm{MHz}\right) \delta 22.5$ (brs) mp: 174.9-175.2 ${ }^{\circ} \mathrm{C}$; Anal. calcd. for $\mathrm{C}_{26} \mathrm{H}_{36} \mathrm{BClN}_{2}$ : C, 73.85; H, 8.58; N, 6.63. Found: C, 73.56; H, 8.43; N, 6.36. 


\section{Synthesis of 34a-I}

A solid of $\mathrm{BI}_{3}(2.13 \mathrm{~g}, 5.44 \mathrm{mmol})$ was added to a suspension of $\mathbf{3 6}(2.00 \mathrm{~g}, 5.44 \mathrm{mmol})$ in hexane/ether $(1: 1,300 \mathrm{~mL})$ at $-10^{\circ} \mathrm{C}$. The resulting solution was stirred for $2 \mathrm{~h}$ at room temperature to afford a red suspension. After solvents were evaporated under reduced pressure, hexane $(200 \mathrm{~mL})$ was added to a residue. The resulting suspension was filtered through Celite pad under argon, and the insoluble salts were washed with hexane. After removing volatiles $\mathrm{Et}_{2} \mathrm{O}(100 \mathrm{ml})$ and $\mathrm{Mg}(1.00 \mathrm{~g})$ were added to the residue. The resulting suspension was stirred for $1 \mathrm{~h}$ at room temperature to remove $\mathrm{I}_{2}$. After solvents were evaporated under reduced pressure, hexane $(200 \mathrm{~mL})$ was added to a residue. The resulting suspension was filtered through Celite pad under argon, and the insoluble salts were washed with hexane. Volatiles were removed from the suspension to give a cream-yellow solid (290 mg, 10\%). An analytically pure sample was obtained from the recrystallization from hexane. ${ }^{1} \mathrm{H}$ NMR $\left(\mathrm{C}_{6} \mathrm{D}_{6}, 500 \mathrm{MHz}\right) \delta 1.19(\mathrm{~d}, J=7 \mathrm{~Hz}, 12 \mathrm{H}), 1.34(\mathrm{~d}, J=7 \mathrm{~Hz}, 12 \mathrm{H})$, $3.14(\mathrm{sep}, J=7 \mathrm{~Hz}, 4 \mathrm{H}), 6.24(\mathrm{~s}, 2 \mathrm{H}), 7.14(\mathrm{~d}, J=8 \mathrm{~Hz}, 4 \mathrm{H}), 7.22(\mathrm{dd}, J=7 \mathrm{~Hz}, 8 \mathrm{~Hz}, 2 \mathrm{H})$; ${ }^{13} \mathrm{C} \mathrm{NMR}\left(\mathrm{C}_{6} \mathrm{D}_{6}, 125 \mathrm{MHz}\right) \delta 24.0\left(\mathrm{CH}_{3}\right), 24.7\left(\mathrm{CH}_{3}\right), 29.0(\mathrm{CH}), 121.6(\mathrm{CH}), 123.9(\mathrm{CH})$, $128.5(\mathrm{CH}), 138.0\left(4^{\circ}\right), 146.3\left(4^{\circ}\right) ;{ }^{11} \mathrm{~B}$ NMR $\left(\mathrm{C}_{6} \mathrm{D}_{6}, 160 \mathrm{MHz}\right) \delta 13.1$ (brs); mp: 166.8-169.4 ${ }^{\circ} \mathrm{C}$ (dec.); Anal. calcd. for $\mathrm{C}_{26} \mathrm{H}_{36} \mathrm{BIN}_{2}: \mathrm{C}, 60.72 ; \mathrm{H}, 7.06 ; \mathrm{N}, 5.45$. Found: $\mathrm{C}$, $60.72 ; \mathrm{H}, 7.13 ; \mathrm{N}, 5.24$.

\section{Synthesis of $(35 \mathrm{a} \cdot \mathrm{DME})_{2}$}

In a glovebox, 34a-Br $(200 \mathrm{mg}, 428 \mu \mathrm{mol})$ and naphthalene $(11.0 \mathrm{mg}, 85.8 \mu \mathrm{mol})$ was dissolved in DME (4 mL). Lithium powder $(30.0 \mathrm{mg}$, $4.32 \mathrm{mmol})$ was added to the solution at $-45{ }^{\circ} \mathrm{C}$ and the resulting suspension was stirred for $35 \mathrm{~h}$ at $-45{ }^{\circ} \mathrm{C}$ to afford a dark red suspension. After solvents were evaporated at room temperature under reduced pressure, hexane (distilled from $n$-buthylllithium solution, $5 \mathrm{~mL}$ ) was added to the residue. The resulting suspension was filtered through Celite pad to remove an excess of lithium, a lithium salt, and lithium naphthalenide. Volatiles were removed from the filtrate to give a pale yellow solid. Thermally unstable colorless crystals were obtained by cooling its hexane solution at $-45^{\circ} \mathrm{C}(58.7 \mathrm{mg}, 28.3 \%)$. Crystals were washed with hexane (distilled from neopentyllithium solution) at $-45{ }^{\circ} \mathrm{C}$ and were quickly dried under vacuum at room temperature. The isolated crystals were placed into a pre-cooled $4 \mathrm{~mL}$ vial at $-45{ }^{\circ} \mathrm{C}$ and were dissolved in THF- $d_{8}$ distilled from Na-K alloy to make a NMR sample. In the THF- $d_{8}$ solution, 35a was stable at room temperature. All the following NMR data contains a decomposed product 38a $(\mathbf{3 5 a}: \mathbf{3 8 a}=93: 7)$ and an equimolar amount of free DME to 35a. ${ }^{1} \mathrm{H}$ NMR $\left(\mathrm{THF}-d_{8}, 500 \mathrm{MHz}\right) \delta 1.12(\mathrm{~d}, J=7 \mathrm{~Hz}, 12 \mathrm{H}), 1.18(\mathrm{~d}, J=7 \mathrm{~Hz}, 12 \mathrm{H}), 3.60$ (sep, $J=7 \mathrm{~Hz}, 4 \mathrm{H}), 6.22(\mathrm{~s}, 2 \mathrm{H}), 7.06$ (brs, 6H); ${ }^{13} \mathrm{C} \mathrm{NMR}\left(\mathrm{THF}-d_{8}, 125 \mathrm{MHz}\right) \delta 24.6\left(\mathrm{CH}_{3}\right)$, $25.3\left(\mathrm{CH}_{3}\right), 28.9(\mathrm{CH}), 119.3(\mathrm{CH}), 123.1(\mathrm{CH}), 125.4(\mathrm{CH}), 147.7\left(4^{\circ}\right), 148.6\left(4^{\circ}\right) ;{ }^{11} \mathrm{~B}$ NMR (THF- $\left.d_{8}, 160 \mathrm{MHz}\right) \delta 45.4$ (brs, $h_{1 / 2}=535 \mathrm{~Hz}$ ); ${ }^{7} \mathrm{Li}$ NMR (THF- $\left.d_{8}, 194 \mathrm{MHz}\right) 0.46$ (brs, $h_{1 / 2}=36 \mathrm{~Hz}$ ).

\section{Synthesis of 35a.(THF)}

In a glove box, a $20 \mathrm{~mL}$ vial equipped with a magnetic stir bar was charged with 34a-Br (500 $\mathrm{mg}, 1.07 \mathrm{mmol})$, lithium powder $(74.2 \mathrm{mg}, 10.7 \mathrm{mmol})$ and naphthalene $(68.6 \mathrm{mg}$, 
$0.535 \mathrm{mmol})$ in THF $(10 \mathrm{~mL})$. The mixture was stirred vigorously at $-45^{\circ} \mathrm{C}$ for $12 \mathrm{~h}$. After the solution was filtered through a pad of Celite ${ }^{\circledR}$ to remove an excess of lithium, a lithium salt, and lithium naphthalenide, solvents were evaporated from the filtrate under reduced pressure. The residue was extracted with pentane and the resulting suspension was filtered through a pad of Celite ${ }^{\circledR}$ to remove inorganic salts. The crude product was recrystallized from pentane at $-45{ }^{\circ} \mathrm{C}$ to give dark crystals $(281 \mathrm{mg}, 66 \%)$ of 35a.(THF) $)_{2}$. The ${ }^{1} \mathrm{H},{ }^{11} \mathrm{~B}$, and ${ }^{13} \mathrm{C}$ NMR data were identical to the values obtained by dissolution of $(\mathbf{3 5 a} \cdot \mathbf{D M E})_{2}$ into THF- $d_{8}$.

\section{Independent synthesis of 38a}

In a glovebox, $\mathrm{LiAlH}_{4}(13.0 \mathrm{mg}, 342 \mu \mathrm{mol})$ was added to a solution of $\mathbf{3 4 a - B r}(200 \mathrm{mg}$, $428 \mu \mathrm{mol})$ in THF ( $3 \mathrm{ml})$ at room temperature and the resulting mixture was stirred for $1 \mathrm{~h}$. After solvents were evaporated under reduced pressure and the vial was brought out from the glovebox, hexane $(25 \mathrm{ml})$ and water $(25 \mathrm{ml})$ was added to a residue. The aqueous phase was extracted twice with $25 \mathrm{ml}$ portions of hexane. The combined organic phase was dried over $\mathrm{Na}_{2} \mathrm{SO}_{4}$ and the solvent was removed under reduced pressure to give a white solid (101 mg, 61.0\%). An analytically pure crystals were obtained from a hexane solution. ${ }^{1} \mathrm{H}\left\{{ }^{11} \mathrm{~B}\right\} \mathrm{NMR}\left(\mathrm{C}_{6} \mathrm{D}_{6}, 500 \mathrm{MHz}\right) \delta 1.220(\mathrm{~d}, J=7 \mathrm{~Hz}, 12 \mathrm{H}), 1.224(\mathrm{~d}, J=7 \mathrm{~Hz}, 12 \mathrm{H}), 3.22$ (sep, $J=7 \mathrm{~Hz}, 4 \mathrm{H}), 4.71(\mathrm{~s}, 1 \mathrm{H}), 6.18(\mathrm{~s}, 2 \mathrm{H}), 7.17(\mathrm{~d}, J=8 \mathrm{~Hz}, 4 \mathrm{H}), 7.23(\mathrm{dd}, J=8 \mathrm{~Hz}, 7$ $\mathrm{Hz}, 2 \mathrm{H}) ;{ }^{13} \mathrm{C}$ NMR $\left(\mathrm{C}_{6} \mathrm{D}_{6}, 125 \mathrm{MHz}\right) \delta 23.9\left(\mathrm{CH}_{3}\right), 24.0\left(\mathrm{CH}_{3}\right), 28.7(\mathrm{CH}), 119.8(\mathrm{CH})$, $123.6(\mathrm{CH}), 127.8(\mathrm{CH}), 139.5\left(4^{\circ}\right), 146.2\left(4^{\circ}\right) ;{ }^{11} \mathrm{~B}$ NMR $\left(\mathrm{C}_{6} \mathrm{D}_{6}, 160 \mathrm{MHz}\right) \delta 22.9\left(\mathrm{brs}, h_{1 / 2}\right.$ $=379 \mathrm{~Hz})$; mp: $122.0-123.7^{\circ} \mathrm{C}$; HRMS-FAB $(\mathrm{m} / \mathrm{z}):[\mathrm{M}]^{+}$calcd for $\mathrm{C}_{26} \mathrm{H}_{37} \mathrm{BN}_{2}, 388.3050$; found, 388.3045 .

\section{Independent synthesis of 38a- $d_{1}$}

In a glovebox, $\mathrm{LiAlD}_{4}(16.5 \mathrm{mg}, 393 \mu \mathrm{mol})$ was added to a solution of $\mathbf{3 4 a - B r}(200 \mathrm{mg}$, $428 \mu \mathrm{mol})$ in THF $(3 \mathrm{~mL})$ at room temperature and the resulting mixture was stirred for $1 \mathrm{~h}$. After solvents were evaporated under reduced pressure and the vial was brought out from the glovebox, hexane $(25 \mathrm{~mL})$ and water $(25 \mathrm{~mL})$ was added to a residue. The aqueous phase was extracted twice with $25 \mathrm{~mL}$ portions of hexane. The combined organic phase was dried over $\mathrm{Na}_{2} \mathrm{SO}_{4}$ and the solvent was removed under reduced pressure. The obtained crude product was purified by recycling HPLC to give a white solid (113 mg, 67.8\%). Analytically pure crystals were obtained from a hexane solution. ${ }^{1} \mathrm{H}$ NMR $\left(\mathrm{C}_{6} \mathrm{D}_{6}, 500\right.$ MHz) $\delta 1.220(\mathrm{~d}, J=7 \mathrm{~Hz}, 12 \mathrm{H}), 1.224(\mathrm{~d}, J=7 \mathrm{~Hz}, 12 \mathrm{H}), 3.22(\mathrm{sep}, J=7 \mathrm{~Hz}, 4 \mathrm{H}), 6.18$ $(\mathrm{s}, 2 \mathrm{H}), 7.16(\mathrm{~d}, J=8 \mathrm{~Hz}, 4 \mathrm{H}), 7.23(\mathrm{dd}, J=8 \mathrm{~Hz}, 7 \mathrm{~Hz}, 2 \mathrm{H}) ;{ }^{2} \mathrm{H} \mathrm{NMR}\left(\mathrm{C}_{6} \mathrm{H}_{6}, 76.8 \mathrm{MHz}\right) \delta$ $4.69\left(\mathrm{brs}, h_{1 / 2}=14 \mathrm{~Hz}\right) ;{ }^{11} \mathrm{~B} \mathrm{NMR}\left(\mathrm{C}_{6} \mathrm{D}_{6}, 160 \mathrm{MHz}\right) \delta 22.7$ (brs, $\left.h_{1 / 2}=268 \mathrm{~Hz}\right) ; \mathrm{mp}$ : 125.6-126.6 ${ }^{\circ} \mathrm{C}$; HRMS-FAB $(\mathrm{m} / \mathrm{z})$ : $[\mathrm{M}]^{+}$calcd for $\mathrm{C}_{26} \mathrm{H}_{36} \mathrm{DBN}_{2}$, 389.3113; found, 389.3106.

\section{Synthesis of 34b}

A $\mathrm{CH}_{2} \mathrm{Cl}_{2}$ solution of $\mathrm{BBr}_{3}(1.0 \mathrm{M}, 7.00 \mathrm{ml}, 7.00 \mathrm{mmol})$ was added to a hexane solution of $39(1.90 \mathrm{~g}, 5.00 \mathrm{mmol}, 25 \mathrm{ml})$ at room temperature under argon atmosphere. After stirred for $5 \mathrm{~min}$ the solvents were evaporated. After dissolution of the residue to $\mathrm{CH}_{2} \mathrm{Cl}_{2}(30 \mathrm{ml})$, 
$\mathrm{NEt}_{3}$ (4.55 g, $45.0 \mathrm{mmol}$ ) was added to the solution. The resulting suspension was stirred for $1 \mathrm{~h}$ at $50{ }^{\circ} \mathrm{C}$. After solvents were evaporated under reduced pressure, hexane $(200 \mathrm{~mL})$ was added to a residue. The resulting suspension was filtered through a pad of Celite ${ }^{\circledR}$ and silica-gel. Volatiles were removed from the filtrate to give a white solid of 34b $(1.60 \mathrm{~g}$, $68 \%$ ). An analytically pure sample was obtained by recrystallization from hexane. ${ }^{1} \mathrm{H}$ NMR $\left(\mathrm{C}_{6} \mathrm{D}_{6}, 500 \mathrm{MHz}\right) \delta 1.28(\mathrm{~d}, J=7 \mathrm{~Hz}, 12 \mathrm{H}), 1.27(\mathrm{~d}, J=7 \mathrm{~Hz}, 12 \mathrm{H}), 3.41(\mathrm{~s}, 4 \mathrm{H}), 3.46$ (sep, $J=7 \mathrm{~Hz}, 4 \mathrm{H}), 7.13(\mathrm{~d}, J=8 \mathrm{~Hz}, 4 \mathrm{H}), 7.19(\mathrm{dd}, J=7 \mathrm{~Hz}, 8 \mathrm{~Hz}, 2 \mathrm{H}) ;{ }^{13} \mathrm{C}$ NMR $\left(\mathrm{C}_{6} \mathrm{D}_{6}, 125\right.$ MHz) $\delta 24.7\left(\mathrm{CH}_{3}\right), 24.9\left(\mathrm{CH}_{3}\right), 28.8(\mathrm{CH}), 52.8\left(\mathrm{CH}_{2}\right), 124.1(\mathrm{CH}), 127.8(\mathrm{CH}), 138.2\left(4^{\circ}\right)$, $147.6\left(4^{\circ}\right) ;{ }^{11} \mathrm{~B}$ NMR $\left(\mathrm{C}_{6} \mathrm{D}_{6}, 160 \mathrm{MHz}\right) \delta 26.8$ (brs); mp: $193.0-196.0{ }^{\circ} \mathrm{C}$ (dec.); Anal. calcd. for $\mathrm{C}_{26} \mathrm{H}_{39} \mathrm{BN}_{2}$ : C, 66.54; H, 8.16; N, 5.97. Found: C, 66.37; H, 8.25; N, 5.94.

\section{Synthesis of 34c}

To a suspension of $40(1.71 \mathrm{~g}, 3.99 \mathrm{mmol})$ and $\mathrm{CaH}_{2}(263 \mathrm{mg}, 6.25 \mathrm{mmol})$ in toluene $(25$ $\mathrm{mL}), \mathrm{BBr}_{3}\left(1 \mathrm{M}\right.$ in $\left.\mathrm{CH}_{2} \mathrm{Cl}_{2}, 4.80 \mathrm{~mL}, 4.80 \mathrm{mmol}\right)$ was added dropwise at $0{ }^{\circ} \mathrm{C}$ and stirred at room temperature for $24 \mathrm{~h}$. Reaction was quenched with ${ }^{i} \operatorname{Pr}_{2} \mathrm{EtN}(1.39 \mathrm{~mL}, 7.98 \mathrm{mmol})$, and the solvents and excess ${ }^{i} \operatorname{Pr}_{2} \mathrm{EtN}$ were removed at reduced pressure. Hexane $(200 \mathrm{~mL})$ was added to the resulting residue, the suspension was filtered through Celite pad and the insoluble salts were washed with hexane. After reducing volatiles, the resulting solution was charged on the top of a silica gel column (hexane) and the product was separated to give a white solid. (975 mg, 47\%) ${ }^{1} \mathrm{H}$ NMR $\left(\mathrm{C}_{6} \mathrm{D}_{6}, 500 \mathrm{MHz}\right) \delta: 1.04(\mathrm{~d}, J=7 \mathrm{~Hz}, 12 \mathrm{H})$, 1.30 (d, $J=7 \mathrm{~Hz}, 12 \mathrm{H}), 2.99$ (sep, $J=7 \mathrm{~Hz}, 4 \mathrm{H}), 6.57$ (dd, $J=6,3 \mathrm{~Hz}, 2 \mathrm{H}), 6.83$ (dd, $J=6$, $3 \mathrm{~Hz}, 2 \mathrm{H}), 7.215(\mathrm{~d}, J=8 \mathrm{~Hz}, 4 \mathrm{H}), 7.216(\mathrm{~d}, J=7 \mathrm{~Hz}, 4 \mathrm{H}), 7.29(\mathrm{dd}, J=8,7 \mathrm{~Hz}, 2 \mathrm{H}) ;{ }^{13} \mathrm{C}$ NMR $\left(\mathrm{C}_{6} \mathrm{D}_{6}, 125 \mathrm{MHz}\right) \delta 24.3\left(\mathrm{CH}_{3}\right), 24.4\left(\mathrm{CH}_{3}\right), 29.1(\mathrm{CH}), 110.9(\mathrm{CH}), 121.2(\mathrm{CH})$, $124.4(\mathrm{CH}), 129.0(\mathrm{CH}), 133.9\left(4^{\circ}\right), 138.2\left(4^{\circ}\right), 147.1\left(4^{\circ}\right) ;{ }^{11} \mathrm{~B}$ NMR $\left(\mathrm{C}_{6} \mathrm{D}_{6}, 160 \mathrm{MHz}\right) \delta$ 24.5 (brs) mp: $147.3-149.0{ }^{\circ} \mathrm{C}$; Anal. calcd. for $\mathrm{C}_{30} \mathrm{H}_{38} \mathrm{BBrN}_{2}$ : C, 69.65; H, 7.40; N, 5.41. Found: C, 69.52; H, 7.50; N, 5.21.

\section{Synthesis of 34d}

A suspension of $41(2.00 \mathrm{~g}, 6.84 \mathrm{mmol})$ and $\mathrm{Mg}(555 \mathrm{mg}, 22.8 \mathrm{mmol})$ in ether $(50 \mathrm{~mL})$ was heated to reflux until the color of the solution became red under argon atmosphere. After cooling the solution to $0{ }^{\circ} \mathrm{C}$, a solution of $\mathrm{BBr}_{3}$ in hexane $(1.00 \mathrm{M} ; 7.50 \mathrm{~mL}, 7.5$ mmol) was added to the mixture at $0{ }^{\circ} \mathrm{C}$. The resulting solution was stirred for $40 \mathrm{~h}$ at $0{ }^{\circ} \mathrm{C}$ to afford a red suspension. After solvents were evaporated under reduced pressure, hexane $(50 \mathrm{~mL})$ was added to a residue. The resulting suspension was filtered through Celite pad to remove magnesium salt under argon, and the insoluble salts were washed with hexane. Volatiles were removed from the filtrate to give a white solid. An analytically pure sample was obtained from the recrystallization from hexane $(2.32 \mathrm{~g}, 89 \%) .{ }^{1} \mathrm{H}$ NMR $\left(\mathrm{C}_{6} \mathrm{D}_{6}\right) \delta: 2.13$ $(\mathrm{s}, 6 \mathrm{H}), 2.19(\mathrm{~s}, 12 \mathrm{H}), 5.98(\mathrm{~s}, 2 \mathrm{H}), 6.79(\mathrm{~s}, 4 \mathrm{H}) ;{ }^{11} \mathrm{~B}$ NMR $\left(\mathrm{C}_{6} \mathrm{D}_{6}, 160 \mathrm{MHz}\right) \delta: 19.0$ (brs), ${ }^{13} \mathrm{C}$ NMR $\left(\mathrm{C}_{6} \mathrm{D}_{6}\right)$ \&: $18.2\left(\mathrm{CH}_{3}\right), 21.0\left(\mathrm{CH}_{3}\right), 118.9\left(\mathrm{CH}_{2}\right), 129.2(\mathrm{CH}), 135.4\left(4^{\circ}\right), 136.6\left(4^{\circ}\right)$, $137.7\left(4^{\circ}\right) .{ }^{11} \mathrm{~B}$ NMR $\left(\mathrm{C}_{6} \mathrm{D}_{6}, 160 \mathrm{MHz}\right) \delta 19.0$ (brs); mp: 153.3-156.4 ${ }^{\circ} \mathrm{C}$ (dec.); Anal. calcd. for $\mathrm{C}_{20} \mathrm{H}_{24} \mathrm{BBrN}_{2}$ : C, 62.70; H, 6.31; N, 7.31. Found: C, 62.69; H, 6.46; N, 7.19. 


\section{Synthesis of 34e}

A $\mathrm{CH}_{2} \mathrm{Cl}_{2}$ solution of $\mathrm{BBr}_{3}(1 \mathrm{M}, 30.0 \mathrm{~mL}, 30.0 \mathrm{mmol})$ was added dropwise to a solution of $42(8.09 \mathrm{~g}, 27.3 \mathrm{mmol})$ in $\mathrm{CH}_{2} \mathrm{Cl}_{2}(200 \mathrm{~mL})$ under argon atmosphere at $0{ }^{\circ} \mathrm{C}$ and stirred at room temperature for $1 \mathrm{~h} .{ }^{i} \operatorname{Pr}_{2} \operatorname{EtN}(8.81 \mathrm{~g}, 68.2 \mathrm{mmol})$ was added to the resulting solution and stirred for $1 \mathrm{~h}$. After solvents were evaporated under reduced pressure, pentane $(500 \mathrm{~mL})$ was added to a residue. The resulting suspension was filtered through Celite pad under argon, and the insoluble salts were washed with hexane. Volatiles were removed from the filtrate to give a white solid $(6.76 \mathrm{~g}, 64 \%) .{ }^{1} \mathrm{H}$ NMR $\left(\mathrm{C}_{6} \mathrm{D}_{6}\right) \delta: 2.13(\mathrm{~s}, 6 \mathrm{H}), 2.32(\mathrm{~s}$, 12H), $3.30(\mathrm{~s}, 4 \mathrm{H}), 6.82(\mathrm{~s}, 4 \mathrm{H}) ;{ }^{11} \mathrm{~B}$ NMR $\left(\mathrm{C}_{6} \mathrm{D}_{6}, 160 \mathrm{MHz}\right) \delta: 25.7(\mathrm{brs}) ;{ }^{13} \mathrm{C} \mathrm{NMR}\left(\mathrm{C}_{6} \mathrm{D}_{6}\right)$ $\delta$ : $18.2\left(\mathrm{CH}_{3}\right), 21.0\left(\mathrm{CH}_{3}\right), 49.8\left(\mathrm{CH}_{2}\right), 129.5(\mathrm{CH}), 135.8\left(4^{\circ}\right), 136.5\left(4^{\circ}\right), 138.5\left(4^{\circ}\right) .{ }^{11} \mathrm{~B}$ NMR $\left(\mathrm{C}_{6} \mathrm{D}_{6}, 160 \mathrm{MHz}\right) \delta 25.7$ (brs); mp: 174.3-178.0 ${ }^{\circ} \mathrm{C}$ (dec.); Anal. calcd. for $\mathrm{C}_{20} \mathrm{H}_{26} \mathrm{BBrN}_{2}$ : C, 62.37; H, 6.80; N, 7.27. Found: C, 62.20; H, 6.86; N, 7.06.

\section{Generation of $35 \mathrm{~b}$ in THF- $d_{8}$}

In a glovebox, 34b $(50 \mathrm{mg}, 106 \mu \mathrm{mol})$ and naphthalene $(2.7 \mathrm{mg}, 21 \mu \mathrm{mol})$ was dissolved in THF- $d_{8}(1 \mathrm{~mL})$. Lithium powder $(7.4 \mathrm{mg}, 1.07 \mathrm{mmol})$ was added to the solution at $-45{ }^{\circ} \mathrm{C}$ and the resulting suspension was stirred for $35 \mathrm{~h}$ at $-45{ }^{\circ} \mathrm{C}$ to afford a dark red suspension. An aliquot of the resulting suspension was pippetted into a screw-capped NMR tube to take the NMR spectra. ${ }^{1} \mathrm{H}$ NMR (THF- $\left.d_{8}, 500 \mathrm{MHz}\right) \delta 1.21(\mathrm{~d}, J=7 \mathrm{~Hz}, 12 \mathrm{H}), 1.22$ $(\mathrm{d}, J=7 \mathrm{~Hz}, 12 \mathrm{H}), 3.44$ (s, 4H), 3.84 (sep, $J=7 \mathrm{~Hz}, 4 \mathrm{H}), 6.97$ (dd, $J=9 \mathrm{~Hz}, 6 \mathrm{~Hz}, 2 \mathrm{H}$ ), $7.02(\mathrm{~d}, J=7 \mathrm{~Hz}, 4 \mathrm{H}) ;{ }^{13} \mathrm{C}$ NMR $\left(\mathrm{THF}-d_{8}, 125 \mathrm{MHz}\right) \delta 25.46\left(\mathrm{CH}_{3}\right), 25.55\left(\mathrm{CH}_{3}\right), 28.9$ $(\mathrm{CH}), 55.1\left(\mathrm{CH}_{2}\right), 123.5(\mathrm{CH}), 124.7(\mathrm{CH}), 149.3\left(4^{\circ}\right), 149.7\left(4^{\circ}\right) ;{ }^{11} \mathrm{~B}$ NMR (THF- $d_{8}, 160$ MHz) $\delta 51.9$ (brs).

\section{Synthesis of 35b·(THF) $)_{2}$}

In a glovebox, 34b (586 mg, $1.25 \mathrm{mmol})$ and naphthalene $(80.0 \mathrm{mg}, 624 \mu \mathrm{mol})$ was dissolved in THF (5 mL). Lithium powder $(43.3 \mathrm{mg}, 6.24 \mathrm{mmol})$ was added to the solution at $-45^{\circ} \mathrm{C}$ and the resulting suspension was stirred for $24 \mathrm{~h}$ at $-45^{\circ} \mathrm{C}$ to afford a dark red suspension. After solvents were evaporated at room temperature under reduced pressure, hexane (distilled from $n$-buthylllithium solution, $20 \mathrm{~mL}$ ) was added to the residue. The resulting suspension was filtered through Celite pad to remove an excess of lithium, a lithium salt, and lithium naphthalenide. Volatiles were removed from the filtrate to give a pale yellow solid. Thermally unstable colorless crystals were obtained by cooling its hexane solution at $-45{ }^{\circ} \mathrm{C}(142 \mathrm{mg}, 21 \%)$. ${ }^{7} \mathrm{Li} \mathrm{NMR}\left(\mathrm{THF}-d_{8}, 194 \mathrm{MHz}\right) 0.68$ (brs, $h_{1 / 2}=$ $35 \mathrm{~Hz}$ ). The ${ }^{1} \mathrm{H},{ }^{11} \mathrm{~B}$, and ${ }^{13} \mathrm{C}$ NMR data were identical to the values of $\mathbf{3 5 b}$ generating in THF- $d_{8}$.

\section{Generation of 35c in THF- $d_{8}$}

In a glovebox, 34c $(51.9 \mathrm{mg}, 107 \mu \mathrm{mol})$ and naphthalene $(7.4 \mathrm{mg}, 58 \mu \mathrm{mol})$ was dissolved in THF- $d_{8}(1 \mathrm{~mL})$. Lithium powder $(2.7 \mathrm{mg}, 389 \mu \mathrm{mol})$ was added to the solution at $-45{ }^{\circ} \mathrm{C}$ and the resulting suspension was stirred for $48 \mathrm{~h}$ at $-45^{\circ} \mathrm{C}$ to afford a dark red suspension. An aliquot of the resulting suspension was pippetted into a screw-capped NMR tube to take the NMR spectra. ${ }^{1} \mathrm{H}$ NMR (THF- $\left.d_{8}, 500 \mathrm{MHz}\right) \delta: 1.00(\mathrm{~d}, J=7 \mathrm{~Hz}, 12 \mathrm{H})$, 
$1.17(\mathrm{~d}, J=7 \mathrm{~Hz}, 12 \mathrm{H}), 3.26(\mathrm{sep}, J=7 \mathrm{~Hz}, 4 \mathrm{H}), 6.18(\mathrm{dd}, J=5,3 \mathrm{~Hz}, 2 \mathrm{H}), 6.44(\mathrm{dd}, J=5$, $3 \mathrm{~Hz}, 2 \mathrm{H}), 7.19(\mathrm{~s}, 6 \mathrm{H}) ;{ }^{13} \mathrm{C}$ NMR $\left(\mathrm{THF}-d_{8}, 125 \mathrm{MHz}\right) \delta 24.7\left(\mathrm{CH}_{3}\right), 25.2\left(\mathrm{CH}_{3}\right), 29.1(\mathrm{CH})$, $108.0(\mathrm{CH}), 116.5(\mathrm{CH}), 123.7(\mathrm{CH}), 126.3(\mathrm{CH}), 141.8\left(4^{\circ}\right), 144.6\left(4^{\circ}\right), 148.3\left(4^{\circ}\right) ;{ }^{11} \mathrm{~B}$ NMR (THF- $\left.d_{8}, 160 \mathrm{MHz}\right) \delta 52.1$ (brs).

\section{Synthesis of 35c·(THF) $)_{2}$}

In a glovebox, 34c $(300 \mathrm{mg}, 580 \mu \mathrm{mol})$ and naphthalene $(37.2 \mathrm{mg}, 290 \mu \mathrm{mol})$ was dissolved in THF $(3.0 \mathrm{~mL})$. Lithium powder $(20.1 \mathrm{mg}, 2.90 \mathrm{mmol})$ was added to the solution at $-45{ }^{\circ} \mathrm{C}$ and the resulting suspension was stirred for $24 \mathrm{~h}$ at $-45{ }^{\circ} \mathrm{C}$ to afford a dark red suspension. After solvents were evaporated at room temperature under reduced pressure, hexane (distilled from $n$-buthylllithium solution, $20 \mathrm{~mL}$ ) was added to the residue. The resulting suspension was filtered through Celite pad to remove an excess of lithium, a lithium salt, and lithium naphthalenide. Volatiles were removed from the filtrate to give a pale yellow solid. Thermally unstable colorless crystals were obtained by cooling its hexane solution at $-45{ }^{\circ} \mathrm{C}(28.3 \mathrm{mg}, 8.3 \%)$. ${ }^{7} \mathrm{Li}$ NMR (THF- $\left.d_{8}, 194 \mathrm{MHz}\right) 0.44$ (brs, $h_{1 / 2}=$ $50 \mathrm{~Hz}$ ). The ${ }^{1} \mathrm{H},{ }^{11} \mathrm{~B}$, and ${ }^{13} \mathrm{C}$ NMR data were identical to the values of $\mathbf{3 5 c}$ generating in THF- $d_{8}$.

\section{Generation of 35d in THF- $d_{8}$}

In a glovebox, 34d $(41.0 \mathrm{mg}, 107 \mu \mathrm{mol})$ and naphthalene $(7.4 \mathrm{mg}, 58 \mu \mathrm{mol})$ was dissolved in THF- $d_{8}(1 \mathrm{~mL})$. Lithium powder $(2.7 \mathrm{mg}, 389 \mu \mathrm{mol})$ was added to the solution at $-45^{\circ} \mathrm{C}$ and the resulting suspension was stirred for $24 \mathrm{~h}$ at $-45^{\circ} \mathrm{C}$ to afford a dark red suspension. An aliquot of the resulting suspension was pippetted into a screw-capped NMR tube to take the NMR spectra. ${ }^{1} \mathrm{H}$ NMR (THF- $\left.d_{8}, 500 \mathrm{MHz}\right) \delta 2.18(\mathrm{~s}, 6 \mathrm{H}), 2.21(\mathrm{~s}, 12 \mathrm{H})$, $6.07(\mathrm{~s}, 2 \mathrm{H}), 6.77(\mathrm{~s}, 4 \mathrm{H}) ;{ }^{13} \mathrm{C}$ NMR $\left(\mathrm{THF}-d_{8}, 125 \mathrm{MHz}\right) \delta 19.5\left(\mathrm{CH}_{3}\right), 21.3\left(\mathrm{CH}_{3}\right), 117.2$ $(\mathrm{CH}), 128.4(\mathrm{CH}), 133.0\left(4^{\circ}\right), 137.1\left(4^{\circ}\right), 148.5\left(4^{\circ}\right) ;{ }^{11} \mathrm{~B}$ NMR (THF- $\left.d_{8}, 160 \mathrm{MHz}\right) \delta 42.9$ (brs).

\section{Generation of $35 \mathrm{e}$}

In a glovebox, 34e $(212 \mathrm{mg}, 550 \mu \mathrm{mol})$ and 4,4'-di-tert-butylbiphenyl (29.3 $\mathrm{mg}, 110$ $\mu \mathrm{mol})$ was dissolved in THF- $d_{8}(5 \mathrm{~mL})$. Lithium powder $(19.1 \mathrm{mg}, 2.75 \mathrm{mmol})$ was added to the solution at $-45^{\circ} \mathrm{C}$ and the resulting suspension was stirred for $15 \mathrm{~h}$ at $-45^{\circ} \mathrm{C}$ to afford a dark green suspension. An aliquot of the resulting suspension was pippetted into a pre-cooled $\left(-45^{\circ} \mathrm{C}\right)$ screw-capped NMR tube, then the NMR tube was quickly brought out from glovebox. The NMR sample was set to pre-cooled $\left(-40{ }^{\circ} \mathrm{C}\right)$ NMR spectrometry. 35e: ${ }^{1} \mathrm{H}$ NMR $\left(\mathrm{THF}-d_{8}, 500 \mathrm{MHz},-40{ }^{\circ} \mathrm{C}\right) \delta 2.20(\mathrm{~s}, 6 \mathrm{H}), 2.36(\mathrm{~s}, 12 \mathrm{H}), 3.34(\mathrm{~s}, 4 \mathrm{H}), 6.77(\mathrm{~s}$, $4 \mathrm{H}) ;{ }^{13} \mathrm{C}$ NMR $\left(\mathrm{THF}-d_{8}, 125 \mathrm{MHz},-40{ }^{\circ} \mathrm{C}\right) \delta 17.8\left(\mathrm{CH}_{3}\right), 20.3\left(\mathrm{CH}_{3}\right), 48.9\left(\mathrm{CH}_{2}\right), 129.6$ (CH), $134.9\left(4^{\circ}\right), 135.9\left(4^{\circ}\right), 147.3\left(4^{\circ}\right) ;{ }^{11} \mathrm{~B}$ NMR (THF- $\left.d_{8}, 160 \mathrm{MHz},-40{ }^{\circ} \mathrm{C}\right) \delta 52.4$ (brs).

In a glovebox, 34e $(41.2 \mathrm{mg}, 107 \mu \mathrm{mol})$ and naphthalene $(2.7 \mathrm{mg}, 21 \mu \mathrm{mol})$ was dissolved in THF- $d_{8}(1 \mathrm{~mL})$. Lithium powder $(7.4 \mathrm{mg}, 1.06 \mathrm{mmol})$ was added to the solution at $-45{ }^{\circ} \mathrm{C}$ and the resulting suspension was stirred for $15 \mathrm{~h}$ at $-45{ }^{\circ} \mathrm{C}$ to afford a dark green suspension. After stirring for $1 \mathrm{~h}$ at $20^{\circ} \mathrm{C}$, An aliquot of the resulting suspension was pippetted into a screw-capped NMR tube to take the NMR spectra. In the ${ }^{1} \mathrm{H}$ NMR 
spectrum, 35e signals were fully disappeared and the new signals which correspond to $43 \mathbf{e}$ increased. 43e: ${ }^{11} \mathrm{~B}$ NMR (THF- $\left.d_{8}, 160 \mathrm{MHz}\right) \delta 0.7\left(\mathrm{~d},{ }^{1} J_{\mathrm{BH}}=64 \mathrm{~Hz}\right)$.

The resulting solution was evaporated and pentane (not dried over $\mathrm{Na}-\mathrm{K}, 50 \mathrm{~mL}$ ) was added. The resulting suspension was filtered through Celite and washed with pentane (50 $\mathrm{mL})$. Volatiles was removed to give colorless oil containing $44 \mathbf{e}$ with $7 \%$ impurity $(25.4 \mathrm{mg}$, 78\%). 44e: ${ }^{1} \mathrm{H}-\mathrm{NMR}\left(\mathrm{C}_{6} \mathrm{D}_{6}\right) \delta 1.89(\mathrm{~s}, 2 \mathrm{H}), 2.14(\mathrm{~s}, 3 \mathrm{H}), 2.19(\mathrm{~s}, 6 \mathrm{H}), 2.26(\mathrm{~s}, 3 \mathrm{H}), 2.30(\mathrm{~s}$, $3 \mathrm{H}), 3.47(\mathrm{dd}, J=9,2 \mathrm{~Hz}, 1 \mathrm{H}), 3.49(\mathrm{~d}, J=8 \mathrm{~Hz}, 1 \mathrm{H}), 3.55(\mathrm{~d}, J=8 \mathrm{~Hz}, 1 \mathrm{H}), 3.56(\mathrm{dd}, J=$ 9, $2 \mathrm{~Hz}, 1 \mathrm{H}), 6.74(\mathrm{~s}, 1 \mathrm{H}), 6.81(\mathrm{~s}, 3 \mathrm{H}) ;{ }^{13} \mathrm{C}$ NMR $\left(\mathrm{C}_{6} \mathrm{D}_{6}, 125 \mathrm{MHz}\right) \delta 18.3\left(\mathrm{CH}_{3}\right), 21.0$ $\left(\mathrm{CH}_{3}\right), 21.1\left(\mathrm{CH}_{3}\right), 46.2\left(\mathrm{CH}_{2}\right), 56.0\left(\mathrm{CH}_{2}\right), 118.6\left(4^{\circ}\right), 126.9(\mathrm{CH}), 129.4(\mathrm{CH}), 129.7(\mathrm{CH})$, $135.1\left(4^{\circ}\right), 135.9\left(4^{\circ}\right), 136.1\left(4^{\circ}\right), 139.4\left(4^{\circ}\right), 146.8\left(4^{\circ}\right) ;{ }^{11} \mathrm{~B} \mathrm{NMR}\left(\mathrm{C}_{6} \mathrm{D}_{6}, 160 \mathrm{MHz}\right) \delta 39.6$ (brs).

\section{Independent Synthesis of $\mathbf{3 8 b}$}

In a glovebox, 34b (601 mg, $1.28 \mathrm{mmol})$ and naphthalene $(93.7 \mathrm{mg}, 731 \mu \mathrm{mol})$ were dissolved in THF $(10 \mathrm{~mL})$. Lithium powder $(72.4 \mathrm{mg}, 10.4 \mathrm{mmol})$ was added to the solution at $-45{ }^{\circ} \mathrm{C}$ and the resulting suspension was stirred for $24 \mathrm{~h}$ at $-45{ }^{\circ} \mathrm{C}$ to afford a dark red suspension. The suspension was filtered through Celite pad to remove an excess of lithium and lithium naphthalenide. To the THF solution of $\mathrm{Et}_{3} \mathrm{NHCl}(882 \mathrm{mg}, 6.41 \mathrm{mmol}$, $10 \mathrm{~mL}$ ), the filtrate was added dropwise at $-45^{\circ} \mathrm{C}$ and the resulting suspension was stirred for $1 \mathrm{~h}$ at room temperature. After solvents were evaporated under reduced pressure, hexane $(20 \mathrm{~mL})$ was added to a residue. The resulting suspension was filtered through a pad of Celite $\AA$, and the residue was washed with hexane. Volatiles were removed from the filtrate and recrystallization from hexane to give a colorless crystal of $\mathbf{3 8 b}$ (438 $\mathrm{mg}, 88 \%$ ). ${ }^{1} \mathrm{H}\left\{{ }^{11} \mathrm{~B}\right\} \operatorname{NMR}\left(\mathrm{C}_{6} \mathrm{D}_{6}, 500 \mathrm{MHz}\right) \delta 1.25(\mathrm{~d}, J=7 \mathrm{~Hz}, 12 \mathrm{H}), 1.30(\mathrm{~d}, J=7 \mathrm{~Hz}, 12 \mathrm{H}), 3.45(\mathrm{~s}$, 4H), 3.50 (sep, $J=7 \mathrm{~Hz}, 4 \mathrm{H}), 4.26(\mathrm{~s}, 1 \mathrm{H}), 7.13-7.14(\mathrm{~m}, 4 \mathrm{H}), 7.20$ (dd, $J=7 \mathrm{~Hz}, 9 \mathrm{~Hz}$, $2 \mathrm{H}) ;{ }^{13} \mathrm{C}$ NMR $\left(\mathrm{C}_{6} \mathrm{D}_{6}, 125 \mathrm{MHz}\right) \delta 24.0\left(\mathrm{CH}_{3}\right), 25.6\left(\mathrm{CH}_{3}\right), 28.7(\mathrm{CH}), 53.8\left(\mathrm{CH}_{2}\right), 123.9$ $(\mathrm{CH}), 127.1(\mathrm{CH}), 140.44\left(4^{\circ}\right), 147.5\left(4^{\circ}\right) ;{ }^{11} \mathrm{~B}$ NMR $\left(\mathrm{C}_{6} \mathrm{D}_{6}, 160 \mathrm{MHz}\right) \delta 29.1$ (brs) ; mp: 130.4-131.0 ${ }^{\circ} \mathrm{C}$ (dec.); Anal. calcd. for $\mathrm{C}_{26} \mathrm{H}_{39} \mathrm{BN}_{2}$ : C, 79.99; H, 10.07; N, 7.18. Found: $\mathrm{C}$, 79.73; H, 10.23; N, 6.99 .

\section{Independent Synthesis of 38c}

In a glovebox, $\mathrm{LiAlH}_{4}(15.6 \mathrm{mg}, 411 \mu \mathrm{mol})$ was added to a solution of $\mathbf{3 4 c}(98.2 \mathrm{mg}, 202$ $\mu \mathrm{mol})$ in THF $(3 \mathrm{ml})$ at room temperature and the resulting mixture was stirred for $1 \mathrm{~h}$. After solvent was evaporated under reduced pressure, hexane $(10 \mathrm{~mL})$ was add to a residue. The resulting suspension was filtered through a Celite pad, and the residue was washed with hexane. Volatiles were removed from the filtrate and recrystallization from hexane gave colorless crystal $(42.1 \mathrm{mg}, 47 \%) .{ }^{1} \mathrm{H}\left\{{ }^{11} \mathrm{~B}\right\} \mathrm{NMR}\left(\mathrm{C}_{6} \mathrm{D}_{6}, 500 \mathrm{MHz}\right) \delta: 1.08(\mathrm{~d}, J=7 \mathrm{~Hz}$, $12 \mathrm{H}), 1.20(\mathrm{~d}, J=7 \mathrm{~Hz}, 12 \mathrm{H}), 3.01(\mathrm{sep}, J=7 \mathrm{~Hz}, 4 \mathrm{H}), 4.97$ (s, 1H), 6.67 (dd, $J=6,3 \mathrm{~Hz}$, $2 \mathrm{H}), 6.90(\mathrm{dd}, J=6,3 \mathrm{~Hz}, 2 \mathrm{H}), 7.23(\mathrm{~d}, J=7 \mathrm{~Hz}, 4 \mathrm{H}), 7.31(\mathrm{dd}, J=8,7 \mathrm{~Hz}, 2 \mathrm{H}) ;{ }^{13} \mathrm{C}$ NMR $\left(\mathrm{C}_{6} \mathrm{D}_{6}, 125 \mathrm{MHz}\right) \delta 23.5\left(\mathrm{CH}_{3}\right), 25.3\left(\mathrm{CH}_{3}\right), 28.9(\mathrm{CH}), 110.6(\mathrm{CH}), 120.6(\mathrm{CH})$, $124.1(\mathrm{CH}), 128.4(\mathrm{CH}), 136.0\left(4^{\circ}\right), 138.4\left(4^{\circ}\right), 146.9\left(4^{\circ}\right) ;{ }^{11} \mathrm{~B}$ NMR $\left(\mathrm{C}_{6} \mathrm{D}_{6}, 160 \mathrm{MHz}\right) \delta$ 26.1 (brs, ${ }^{1} J_{\mathrm{B}-\mathrm{H}}$ was not observed.) mp: $126.2-130.0{ }^{\circ} \mathrm{C}$ (dec); Anal. calcd. for $\mathrm{C}_{30} \mathrm{H}_{39} \mathrm{BN}_{2}$ : C, 82.18; H, 8.97; N, 6.39. Found: C, 81.94; H, 9.20; N, 6.41. 


\section{Preparation of Stock Solution A of Boryllithium 35a}

In a glove box, 34a-Br $(4.67 \mathrm{~g}, 10.0 \mathrm{mmol})$ and naphthalene $(256 \mathrm{mg}, 2.00 \mathrm{mmol})$ was dissolved in THF $(40 \mathrm{~mL})$. Lithium powder $(347 \mathrm{mg}, 50 \mathrm{mmol})$ was added to the solution at $-45^{\circ} \mathrm{C}$ and the resulting suspension was stirred for $24 \mathrm{~h}$ at $-45^{\circ} \mathrm{C}$ to afford a dark red suspension. The suspension was filtered through a Celite ${ }^{\circledR}$ pad to remove an excess of lithium and lithium naphthalenide. THF was added to the filtrate to make boryllithium 35a stock solution A (100 mM, $100 \mathrm{~mL}, 10.0 \mathrm{mmol})$, which can be stocked for a few months at $-45{ }^{\circ} \mathrm{C}$.

\section{Preparation of Stock Solution B of Boryllithium 35b}

In a glove box, 34b $(1.76 \mathrm{mg}, 3.75 \mathrm{mmol})$ and naphthalene $(96.0 \mathrm{mg}, 750 \mu \mathrm{mol})$ was dissolved in THF $(15 \mathrm{~mL})$. Lithium powder $(130 \mathrm{mg}, 18.7 \mathrm{mmol})$ was added to the solution at $-45^{\circ} \mathrm{C}$ and the resulting suspension was stirred for $24 \mathrm{~h}$ at $-45^{\circ} \mathrm{C}$ to afford a dark red suspension. The suspension was filtered through a Celite ${ }^{\circledR}$ pad to remove an excess of lithium and lithium naphthalenide. THF was added to the filtrate to make boryllithium $\mathbf{3 5 b}$ stock solution B $(75.0 \mathrm{mM}, 50 \mathrm{~mL}, 3.75 \mathrm{mmol})$, which can be stocked for a few months at $-45{ }^{\circ} \mathrm{C}$.

General procedure for the reaction of 35a and 35b with electrophiles $\left(\mathrm{H}_{2} \mathrm{O}, \mathrm{D}_{2} \mathrm{O}\right.$, MeOTf, $n$-BuCl, BnCl, $n$-BuBr, BnBr, PhCHO, PhCOCl, $\mathrm{PhCO}{ }_{2} \mathrm{Ph},(\mathrm{PhCO})_{2} \mathrm{O}$, $(\mathrm{PhO})_{2} \mathrm{CO}, \mathrm{Boc}_{2} \mathrm{O}, \mathrm{CO}_{2}, \mathrm{PhF}$, and $\mathrm{C}_{6} \mathrm{~F}_{6}$ )

In a glovebox, 34a-Br (500 mg, $1.07 \mathrm{mmol})$ and naphthalene $(27.5 \mathrm{mg}, 214 \mu \mathrm{mol})$ was dissolved in THF $(10 \mathrm{~mL})$. Lithium powder $(75.0 \mathrm{mg}, 10.8 \mathrm{mmol})$ was added to the solution at $-45{ }^{\circ} \mathrm{C}$ and the resulting suspension was stirred for $35 \mathrm{~h}$ at $-45{ }^{\circ} \mathrm{C}$ to afford a dark red suspension. The resulting suspension was filtered through Celite pad to remove an excess of lithium and lithium naphthalenide. The filtrate was diluted with THF to $25.0 \mathrm{~mL}$. To a $0.50 \mathrm{~mL}$ aliquot $(21.4 \mathrm{mmol})$ of the resulting boryllithium solution, excess of $\mathrm{H}_{2} \mathrm{O}$, $\mathrm{D}_{2} \mathrm{O}$, or a THF solution of $n$ - $\mathrm{BuCl}(910 \mu \mathrm{L}, 47.1 \mathrm{mM}, 42.8 \mathrm{mmol})$ was added at $-45^{\circ} \mathrm{C}$ and the resulting suspension was stirred for $10 \mathrm{~min}$ at room temperature. [For the reaction of MeOTf, solvents were removed from the boryllithium solution and ether $(500 \mu \mathrm{L})$ was added to the residue to make an ether solution of boryllithium. To the resulting ether solution, an ether solution of MeOTf $(500 \mu \mathrm{L}, 47.1 \mathrm{mM}, 1.1 \mathrm{eq})$ was added at $-45{ }^{\circ} \mathrm{C}$ and the resulting suspension was stirred for $10 \mathrm{~min}$ at room temperature.]

To the stock solution A $(100 \mathrm{mM}, 0.5 \mathrm{~mL}, 50 \mu \mathrm{mol}), \mathrm{BnCl}(9.5 \mathrm{mg}, 75 \mu \mathrm{mol}), n$ - $\mathrm{BuBr}$ (103 mg, $75 \mu \mathrm{mol}), \mathrm{BnBr}(12.8 \mathrm{mg}, 75 \mu \mathrm{mol}), 1$ eq. or 3 eq. of PhCHO (1 eq.; $5.3 \mathrm{mg}, 50$ $\mu \mathrm{mol}, 3$ eq.; $15.9 \mathrm{mg}, 150 \mu \mathrm{mol}), \mathrm{PhCOCl}(10.5 \mathrm{mg}, 75 \mu \mathrm{mol}), \mathrm{PhCO}_{2} \mathrm{Ph}(9.9 \mathrm{mg}, 75$ $\mu \mathrm{mol}),(\mathrm{PhCO})_{2} \mathrm{O}(11.3 \mathrm{mg}, 75 \mu \mathrm{mol}),(\mathrm{PhO})_{2} \mathrm{CO}(10.7 \mathrm{mg}, 75 \mu \mathrm{mol}), \mathrm{Boc}_{2} \mathrm{O}(10.0 \mathrm{mg}, 75$ $\mu \mathrm{mol}$ ), excess $\mathrm{CO}_{2}$ [at $1 \mathrm{~atm}$ after removal of argon with freeze thaw], $\mathrm{PhF}$ (4.8 $\mathrm{mg}, 75$ $\mu \mathrm{mol})$, or $\mathrm{C}_{6} \mathrm{~F}_{6}(14.0 \mathrm{mg}, 75 \mu \mathrm{mol})$ was added at $-45{ }^{\circ} \mathrm{C}$ [in the case of $\mathrm{CO}_{2}:-78{ }^{\circ} \mathrm{C}$ ] and the resulting suspension was stirred for $10 \mathrm{~min}$ [in the case of $\mathrm{C}_{6} \mathrm{~F}_{6}: 24 \mathrm{~h}$ ] at room temperature.

To the stock solution B $(75.0 \mathrm{mM}, 10.0 \mathrm{~mL}, 750 \mu \mathrm{mol}), \mathrm{PhCOCl}(158 \mathrm{mg}, 1.13 \mathrm{mmol})$, or excess $\mathrm{CO}_{2}$ [at $1 \mathrm{~atm}$ after removal of argon with freeze thaw], was added at $-45^{\circ} \mathrm{C}$ [in 
the case of $\mathrm{CO}_{2}:-78{ }^{\circ} \mathrm{C}$ ] and the resulting suspension was stirred for $10 \mathrm{~min}$ at room temperature.

After solvents were evaporated under reduced pressure, $\mathrm{C}_{6} \mathrm{D}_{6}(600 \mu \mathrm{L}$, including phenanthlene as an internal standard, $71.4 \mathrm{mM}$ ) was added to a residue to make NMR samples. The characterizations of the products were carried out by comparison with independently synthesized compounds. The product yields were estimated from the integral ratio of the products over the internal standard in their ${ }^{1} \mathrm{H}$ NMR spectra.

\section{Reexamination of $35 \mathrm{a}$ with $\mathrm{D}_{2} \mathrm{O}$}

In a glovebox, 34a-Br (100 mg, $214 \mu \mathrm{mol})$ and naphthalene $(5.5 \mathrm{mg}, 43 \mu \mathrm{mol})$ was dissolved in THF $(2 \mathrm{~mL})$. Lithium powder $(7.5 \mathrm{mg}, 1.07 \mathrm{mmol})$ was added to the solution at $-45^{\circ} \mathrm{C}$ and the resulting suspension was stirred for $35 \mathrm{~h}$ at $-45^{\circ} \mathrm{C}$ to afford a dark red suspension. The resulting suspension was filtered through Celite pad to remove an excess of lithium and lithium naphthalenide. $\mathrm{D}_{2} \mathrm{O}$ was added at $-45{ }^{\circ} \mathrm{C}$ and the resulting suspension was stirred for $10 \mathrm{~min}$ at room temperature. After phenanthlene $(38.1 \mathrm{mg}, 214$ $\mu \mathrm{mol})$ was added to the suspension, solvents were evaporated under reduced pressure. Then $\mathrm{C}_{6} \mathrm{D}_{6}(600 \mu \mathrm{L})$ was added to a residue to make NMR samples. The characterizations of the products were carried out by comparison with independently synthesized compounds. The product yields were estimated from the integral ratio of the products over the internal standard in its ${ }^{1} \mathrm{H}$ NMR spectrum $\left(97 \% \mathbf{3 8 a}-\boldsymbol{d}_{1}\right.$ with $\left.2.6 \% \mathbf{3 8 a}\right)$.

\section{Independent synthesis of 55}

In a glovebox, a solution of MeLi in hexane (1.04 M; $1.41 \mathrm{~mL}, 1.47 \mathrm{mmol})$ was added to a solution of 34a-Br $(200 \mathrm{mg}, 428 \mu \mathrm{mol})$ in THF $(3 \mathrm{~mL})$ at room temperature and the resulting mixture was stirred for $4 \mathrm{~h}$. After solvents were evaporated under reduced pressure and the vial was brought out from the glovebox, hexane $(20 \mathrm{~mL})$ and water $(25$ $\mathrm{mL}$ ) was added to a residue. The aqueous phase was extracted twice with $20 \mathrm{~mL}$ portions of hexane. The combined organic phase was dried over $\mathrm{Na}_{2} \mathrm{SO}_{4}$ and the solvent was removed under reduced pressure. Purified by recycling HPLC to give a white solid (102 mg, 59.2\%). Analytically pure crystals were obtained from a hexane solution. ${ }^{1} \mathrm{H}$ NMR $\left(\mathrm{C}_{6} \mathrm{D}_{6}, 500\right.$ MHz) $\delta 0.31(\mathrm{~s}, 3 \mathrm{H}), 1.21(\mathrm{~d}, J=7 \mathrm{~Hz}, 12 \mathrm{H}), 1.22(\mathrm{~d}, J=7 \mathrm{~Hz}, 12 \mathrm{H}), 3.19(\mathrm{sep}, J=7 \mathrm{~Hz}$, $4 \mathrm{H}), 6.15(\mathrm{~s}, 2 \mathrm{H}), 7.16(\mathrm{~d}, J=7 \mathrm{~Hz}, 4 \mathrm{H}), 7.23(\mathrm{dd}, J=9 \mathrm{~Hz}, 7 \mathrm{~Hz}, 2 \mathrm{H}),{ }^{11} \mathrm{~B}$ NMR $\left(\mathrm{C}_{6} \mathrm{D}_{6}\right.$, $160 \mathrm{MHz}) 27.9$ (brs, $\left.h_{1 / 2}=307 \mathrm{~Hz}\right) ;{ }^{13} \mathrm{C}$ NMR $\left(\mathrm{C}_{6} \mathrm{D}_{6}, 126 \mathrm{MHz}\right)-6.0\left(\mathrm{br}, \mathrm{B}-\mathrm{CH}_{3}\right), 24.1$ $\left(\mathrm{CH}_{3}\right), 24.6\left(\mathrm{CH}_{3}\right), 29.0(\mathrm{CH}), 119.0(\mathrm{CH}), 123.7(\mathrm{CH}), 127.7(\mathrm{CH}), 139.3\left(4^{\circ}\right), 146.5\left(4^{\circ}\right)$. mp: 103.7-104.7 ${ }^{\circ} \mathrm{C}$; HRMS-FAB $(\mathrm{m} / z)$ : $[\mathrm{M}]^{+}$calcd for $\mathrm{C}_{27} \mathrm{H}_{39} \mathrm{BN}_{2}, 402.3206$; found, 402.3205 .

\section{Isolation of 56}

In a glovebox, lithium granular $(75.0 \mathrm{mg}, 5.30 \mathrm{mmol})$ was added to a solution of $\mathbf{3 4 a - B r}$ (500 mg, $1.06 \mathrm{mmol})$ and naphthalene $(26.0 \mathrm{mg}, 203 \mu \mathrm{mol})$ in THF $(10 \mathrm{~mL})$ at $-45^{\circ} \mathrm{C}$ under argon atmosphere and stirred for $12 \mathrm{~h}$ at $-45^{\circ} \mathrm{C}$. After the resulting suspension was filtered through Celite pad to remove an excess of lithium and lithium naphthalenide, 1chlorobutane $\left(149 \mathrm{mg}, 1.60 \mathrm{mmol}\right.$ ) was added to the solution at $-45{ }^{\circ} \mathrm{C}$ and the resulting 
mixture was stirred for $10 \mathrm{~min}$ at room temperature. After removal of solvent, hexane (25 $\mathrm{mL}$ ) was added to a residue. The resulting suspension was filtered through Celite pad to remove a lithium salt under argon, and the solids were washed with hexane. Volatiles were removed from the filtrate. Purified by recycling HPLC to give a white solid (132 $\mathrm{mg}$, $69.4 \%)$. Analytically pure crystals were obtained from a methanol solution. ${ }^{1} \mathrm{H} N M R\left(\mathrm{C}_{6} \mathrm{D}_{6}\right.$, $500 \mathrm{MHz}) \delta 0.66(\mathrm{t}, J=7 \mathrm{~Hz}, 3 \mathrm{H}), 0.98-1.07(\mathrm{~m}, 4 \mathrm{H}), 1.18(\mathrm{t}, J=7 \mathrm{~Hz}, 2 \mathrm{H}), 1.20(\mathrm{~d}, J=7$ $\mathrm{Hz}, 6 \mathrm{H}), 1.28$ (d, $J=7 \mathrm{~Hz}, 6 \mathrm{H}), 3.26(\mathrm{sep}, J=8 \mathrm{~Hz}, 4 \mathrm{H}), 6.18(\mathrm{~s}, 2 \mathrm{H}), 7.16$ (d, $J=8 \mathrm{~Hz}$, $2 \mathrm{H}), 7.23(\mathrm{dd}, J=8 \mathrm{~Hz}, 7 \mathrm{~Hz}, 2 \mathrm{H}) ;{ }^{11} \mathrm{~B} \mathrm{NMR}\left(\mathrm{C}_{6} \mathrm{D}_{6}, 160 \mathrm{MHz}\right) 27.9$ (brs, $\left.h_{1 / 2}=286 \mathrm{~Hz}\right)$; ${ }^{13} \mathrm{C}$ NMR $\left(\mathrm{C}_{6} \mathrm{D}_{6}, 126 \mathrm{MHz}\right) 12.1$ (br, B- $\left.\mathrm{CH}_{2}\right), 14.0\left(\mathrm{CH}_{3}\right), 23.7\left(\mathrm{CH}_{3}\right), 25.4\left(\mathrm{CH}_{3}\right), 26.4$ $\left(\mathrm{CH}_{2}\right), 28.2\left(\mathrm{CH}_{2}\right), 28.6(\mathrm{CH}), 119.3(\mathrm{CH}), 120.1(\mathrm{CH}), 123.7(\mathrm{CH}), 139.4\left(4^{\circ}\right), 146.4\left(4^{\circ}\right)$, mp: 81.6-82.4 ${ }^{\circ} \mathrm{C}$; HRMS-FAB $(\mathrm{m} / \mathrm{z})$ : $[\mathrm{M}]^{+}$calcd for $\mathrm{C}_{30} \mathrm{H}_{45} \mathrm{BN}_{2}, 444.3676$; found, 444.3674 .

\section{Independent Synthesis of 57}

To the THF solution of 34a-Br (488 mg, $1.04 \mathrm{mmol}, 20 \mathrm{~mL}), \mathrm{PhCH}_{2} \mathrm{~K}(204 \mathrm{mg}, 1.57$ mmol) was added under argon atmosphere at room temperature and the resulting solution was stirred at room temperature for $3 \mathrm{~h}$. After quenched by ${ }^{i} \mathrm{Pr}_{2} \mathrm{EtNHCl}$ (344 mg, 2.08 mmol), solvent was evaporated under reduced pressure and hexane $(50 \mathrm{~mL})$ was added to a residue. The resulting suspension was filtered through a Celite pad, and the residue was washed with hexane. Volatiles were removed from the filtrate and recrystallization from hexane gave colorless crystal $(263 \mathrm{mg}, 53 \%){ }^{1} \mathrm{H}$ NMR $\left(\mathrm{C}_{6} \mathrm{D}_{6}\right) \delta: 1.13(\mathrm{~d}, J=7 \mathrm{~Hz}, 12 \mathrm{H})$, $1.16(\mathrm{~d}, J=7 \mathrm{~Hz}, 12 \mathrm{H}), 2.42(\mathrm{~s}, 2 \mathrm{H}), 3.12(\mathrm{sep}, J=7 \mathrm{~Hz}, 4 \mathrm{H}), 6.18(\mathrm{~s}, 2 \mathrm{H}), 6.62(\mathrm{~d}, J=7$ $\mathrm{Hz}, 2 \mathrm{H}), 6.84(\mathrm{t}, J=7 \mathrm{~Hz}, 1 \mathrm{H}), 6.91(\mathrm{t}, J=7 \mathrm{~Hz}, 2 \mathrm{H}), 7.14(\mathrm{~d}, J=7 \mathrm{~Hz}, 4 \mathrm{H}), 7.24(\mathrm{dd}, J=$ 8, $7 \mathrm{~Hz}, 2 \mathrm{H}) ;{ }^{13} \mathrm{C}$ NMR $\left(\mathrm{C}_{6} \mathrm{D}_{6}, 125 \mathrm{MHz}\right) \delta 20.9\left(\mathrm{br}, \mathrm{CH}_{2}\right), 23.2\left(\mathrm{CH}_{3}\right), 25.9\left(\mathrm{CH}_{3}\right), 28.7$ $(\mathrm{CH}), 119.6(\mathrm{CH}), 123.7(\mathrm{CH}), 124.5(\mathrm{CH}), 127.9(\mathrm{CH}), 128.2(\mathrm{CH}), 129.1(\mathrm{CH}), 139.0$ $\left(4^{\circ}\right), 140.6\left(4^{\circ}\right), 146.4\left(4^{\circ}\right) ;{ }^{11} \mathrm{~B}$ NMR $\left(\mathrm{C}_{6} \mathrm{D}_{6}, 160 \mathrm{MHz}\right) \delta 26.6$ (brs) mp: 124.1-125.5 ${ }^{\circ} \mathrm{C}$; Anal. calcd. for $\mathrm{C}_{33} \mathrm{H}_{43} \mathrm{BN}_{2}$ : C, 82.83; H, 9.06; N, 5.85. Found: C, 82.92; H, 9.01; N, 5.83.

\section{Large Scale Synthesis of 58}

In a glovebox, lithium granular $(70.0 \mathrm{mg}, 10.1 \mathrm{mmol})$ was added to a solution of $\mathbf{3 4 a}-\mathbf{B r}$ $(500 \mathrm{mg}, 1.07 \mathrm{mmol})$ and naphthalene $(52.0 \mathrm{mg}, 406 \mu \mathrm{mol})$ in THF $(10 \mathrm{ml})$ at $-45^{\circ} \mathrm{C}$ under argon atmosphere and stirred for $12 \mathrm{~h}$ at $-45^{\circ} \mathrm{C}$. After the resulting suspension was filtered through Celite pad to remove an excess of lithium and lithium naphthalenide, solvents were evaporated under reduced pressure and the residue was dissolved in diethyl ether $(20 \mathrm{ml})$. Benzaldehyde $(1.05 \mathrm{~g}, 9.85 \mathrm{mmol})$ was added to the solution at $-45{ }^{\circ} \mathrm{C}$ and the resulting mixture was stirred for $10 \mathrm{~min}$ at room temperature. After removal of solvent, the residue was dissolved in a mixture of hexane and dichloromethane $(1: 2)$. The resulting solution was charged on the top of a silica gel column (hexane : dichloromethane $=1: 2$ ) and the product was separated to give a white solid (240 mg, $485 \mu \mathrm{mol}, 45.4 \%$ ). Analytically pure crystals were obtained from a hexane solution. ${ }^{1} \mathrm{H}$ NMR $\left(\mathrm{C}_{6} \mathrm{D}_{6}, 500\right.$ MHz) $0.85(\mathrm{~d}, J=4 \mathrm{~Hz}, 1 \mathrm{H}), 1.10(\mathrm{~d}, J=7 \mathrm{~Hz}, 6 \mathrm{H}), 1.15(\mathrm{~d}, J=7 \mathrm{~Hz}, 6 \mathrm{H}), 1.18(\mathrm{~d}, J=7$ $\mathrm{Hz}, 6 \mathrm{H}), 1.28(\mathrm{~d}, J=7 \mathrm{~Hz}, 6 \mathrm{H}), 3.11(\mathrm{sep}, J=7 \mathrm{~Hz}, 2 \mathrm{H}), 3.27$ (sep, $J=7 \mathrm{~Hz}, 2 \mathrm{H}), 4.64$ (d, $J=4 \mathrm{~Hz}, 1 \mathrm{H}), 6.15(\mathrm{~s}, 2 \mathrm{H}), 6.81(\mathrm{~d}, J=7 \mathrm{~Hz}, 2 \mathrm{H}), 6.90(\mathrm{~d}, J=7 \mathrm{~Hz}, 1 \mathrm{H}), 6.96(\mathrm{t}, J=7 \mathrm{~Hz}$, 
2H), $7.11(\mathrm{dd}, J=6 \mathrm{~Hz}, 8 \mathrm{~Hz}, 2 \mathrm{H}), 7.1(\mathrm{dd}, J=6 \mathrm{~Hz}, 8 \mathrm{~Hz}, 2 \mathrm{H}), 7.24(\mathrm{t}, J=8 \mathrm{~Hz}, 2 \mathrm{H}) ;{ }^{11} \mathrm{~B}$ NMR $\left(\mathrm{C}_{6} \mathrm{D}_{6}, 160 \mathrm{MHz}\right) 25.3\left(\mathrm{brs}, h_{1 / 2}=314 \mathrm{~Hz}\right) ;{ }^{13} \mathrm{C} \mathrm{NMR}\left(\mathrm{C}_{6} \mathrm{D}_{6}, 126 \mathrm{MHz}\right.$, two ipso $4^{\circ}$ carbons connected to nitrogen atoms are magnetically equivalent) $\delta 23.0\left(\mathrm{CH}_{3}\right), 23.1\left(\mathrm{CH}_{3}\right)$, $26.1\left(\mathrm{CH}_{3}\right), 26.2\left(\mathrm{CH}_{3}\right), 28.65(\mathrm{CH}), 28.71(\mathrm{CH}), 65.3(\mathrm{br}, \mathrm{B}-\mathrm{CH}(\mathrm{OH})), 120.1(\mathrm{CH}), 123.6$ $(\mathrm{CH}), 126.0(\mathrm{CH}), 126.2(\mathrm{CH}), 127.9(\mathrm{CH}), 128.1(\mathrm{CH}), 128.4(\mathrm{CH}), 139.0\left(4^{\circ}, \mathrm{N}-\mathrm{C}\right)$, $145.6\left(4^{\circ}\right), 146.5\left(4^{\circ}\right), 146.8\left(4^{\circ}\right) . \mathrm{mp}: 139.6-140.4{ }^{\circ} \mathrm{C}$; HRMS-FAB $(\mathrm{m} / z):[\mathrm{M}]^{+}$calcd for $\mathrm{C}_{33} \mathrm{H}_{43} \mathrm{BN}_{2} \mathrm{O}$, 494.3468; found, 494.3465.

\section{Preparation of stock solution $C$ of boryllithium 35a}

In a glovebox, a $80 \mathrm{~mL}$ vial equipped with a glass magnetic stir bar was charged with 1 (3.59 g, $7.69 \mathrm{mmol})$, Li powder $(267 \mathrm{mg}, 38.5 \mathrm{mmol})$, and naphthalene (493 $\mathrm{mg}, 3.85$ mmol). After cooling the vial to $-45^{\circ} \mathrm{C}$, THF $(15 \mathrm{~mL})$ was added to the vial. The resulting mixture was stirred for $12 \mathrm{~h}$ at $-45{ }^{\circ} \mathrm{C}$. After a portion of the reaction mixture was monitored by ${ }^{11} \mathrm{~B}$ NMR to confirm the reaction was complete, the resulting mixture was filtered through a pad of Celite ${ }^{\circledR}$ and the residue was washed with THF. The filtrate was diluted to $25 \mathrm{~mL}$ with volumetric flask to give stock solution C (boryllithium 35a, 0.308 M).

\section{Independent synthesis of 59 by the reaction of 35a with 5 eq of $\mathrm{PhCHO}$}

In a glovebox, a $4 \mathrm{~mL}$ vial equipped with a glass stir bar was charged with $\mathrm{PhCHO}$ (204 $\mu \mathrm{L}, 2.00 \mathrm{mmol})$. To the vial, an aliquot of stock solution $\mathbf{C}$ of boryllithium 35a $(0.308 \mathrm{M}$, $1.30 \mathrm{~mL}, 0.400 \mathrm{mmol}$ ) was added dropwise at room temperature. After the reaction mixture was stirred at room temperature for $1 \mathrm{~h}$, solvents were evaporated under reduced pressure. $\mathrm{CHCl}_{3}$ was added to the residue and the resulting solution was subjected to recycle GPC with $\mathrm{CHCl}_{3}$ eluent to give a gummy yellow solids of borylester $59\left(\mathrm{R}_{\mathrm{T}}=51 \mathrm{~min}, 105 \mathrm{mg}\right.$, 44\%). ${ }^{1} \mathrm{H}$ NMR $\left(\mathrm{C}_{6} \mathrm{D}_{6}, 500 \mathrm{MHz}\right) \delta: 0.84(\mathrm{~d}, J=7 \mathrm{~Hz}, 6 \mathrm{H}), 1.10(\mathrm{~d}, J=7 \mathrm{~Hz}, 6 \mathrm{H}), 1.18(\mathrm{~d}$, $J=7 \mathrm{~Hz}, 6 \mathrm{H}), 1.45$ (d, $J=7 \mathrm{~Hz}, 6 \mathrm{H}), 2.97$ (sep, $J=7 \mathrm{~Hz}, 2 \mathrm{H}), 3.45$ (sep, $J=7 \mathrm{~Hz}, 2 \mathrm{H})$, $6.17(\mathrm{~s}, 2 \mathrm{H}), 6.61(\mathrm{~s}, 1 \mathrm{H}), 6.82-6.86(\mathrm{~m}, 1 \mathrm{H}), 6.89-6.94(\mathrm{~m}, 4 \mathrm{H}), 6.97-7.08(\mathrm{~m}, 5 \mathrm{H}), 7.20-$ $7.24(\mathrm{~m}, 4 \mathrm{H}), 7.33-7.36(\mathrm{~m}, 2 \mathrm{H}) .{ }^{11} \mathrm{~B}$ NMR $\left(\mathrm{C}_{6} \mathrm{D}_{6}, 160 \mathrm{MHz}\right) \delta 25.3$ (brs). ${ }^{13} \mathrm{C}$ NMR $\left(\mathrm{C}_{6} \mathrm{D}_{6}\right.$, $126 \mathrm{MHz}) \delta 22.6\left(\mathrm{CH}_{3}\right), 23.2\left(\mathrm{CH}_{3}\right), 26.0\left(\mathrm{CH}_{3}\right), 26.2\left(\mathrm{CH}_{3}\right), 28.7(\mathrm{CH}), 28.9(\mathrm{CH}), 68.9$ (br, $\mathrm{CH}), 120.5(\mathrm{NCH}), 123.7(\mathrm{CH}), 124.0(\mathrm{CH}), 126.9(\mathrm{CH}), 127.8(\mathrm{CH}), 127.9(\mathrm{CH})$, $128.0(\mathrm{CH}), 128.3(\mathrm{CH}), 128.4(\mathrm{CH}), 130.1(\mathrm{CH}), 131.0\left(4^{\circ}\right), 132.3(\mathrm{CH}), 139.3(\mathrm{CH})$, $141.3\left(4^{\circ}\right), 145.9\left(4^{\circ}\right), 146.4\left(4^{\circ}\right), 165.9(\mathrm{C}=\mathrm{O})$; IR $(\mathrm{KBr}): v_{\mathrm{CO}}=1719 \mathrm{~cm}^{-1}$; Anal. Calcd for $\mathrm{C}_{40} \mathrm{H}_{47} \mathrm{BN}_{2} \mathrm{O}_{2}:$ C, 80.26; H, 7.91; N, 4.68. Found: C, 80.00; H, 8.19; N, 4.49.

\section{Synthesis of 60a}

In a glovebox, a $20 \mathrm{~mL}$ vial equipped with a glass magnetic stir bar was charged with an aliquot of stock solution $\mathbf{C}$ of boryllithium 35a, $(10.0 \mathrm{~mL}, 3.08 \mathrm{mmol})$. To the vial, benzoyl chloride ( $649 \mathrm{mg}, 4.61 \mathrm{mmol}$ ) was added dropwise at room temperature, and then the reaction mixture was stirred for $12 \mathrm{~h}$ at room temperature. After removing all volatiles, the crude product was purified by silica gel chromatography with hexane : $\mathrm{CH}_{2} \mathrm{Cl}_{2}=3: 1$ eluent to give yellow solids (856 mg, 57\%). ${ }^{1} \mathrm{H}$ NMR $\left(\mathrm{C}_{6} \mathrm{D}_{6}, 500 \mathrm{MHz}\right) \delta 1.20(\mathrm{~d}, J=7 \mathrm{~Hz}$, $12 \mathrm{H}), 1.27(\mathrm{~d}, J=7 \mathrm{~Hz}, 12 \mathrm{H}), 3.41$ (sept, $J=7 \mathrm{~Hz}, 4 \mathrm{H}), 6.24(\mathrm{~s}, 2 \mathrm{H}), 6.90-6.92(\mathrm{~m}, 3 \mathrm{H})$, 
7.01-7.09 (m, 6H), 7.79-7.80 (m, 2H). ${ }^{11} \mathrm{~B}$ NMR $\left(\mathrm{C}_{6} \mathrm{D}_{6}, 160 \mathrm{MHz}\right) \delta 21.8$ (brs). ${ }^{13} \mathrm{C}$ NMR $\left(\mathrm{C}_{6} \mathrm{D}_{6}, 126 \mathrm{MHz}\right) \delta 23.5\left(\mathrm{CH}_{3}\right), 25.9\left(\mathrm{CH}_{3}\right), 28.8(\mathrm{CH}), 120.2(\mathrm{NCH}), 123.8(\mathrm{CH}), 128.1$ $(\mathrm{CH}), 128.3(\mathrm{CH}), 128.5(\mathrm{CH}), 132.4(\mathrm{CH}), 137.9\left(4^{\circ}\right), 141.8\left(4^{\circ}\right), 145.9\left(4^{\circ}\right), 218.7(\mathrm{br}$, $\mathrm{C}=\mathrm{O})$; IR (KBr): $v_{\mathrm{CO}}=1618 \mathrm{~cm}^{-1}$; mp: 126.7-128.5 ${ }^{\circ} \mathrm{C}$ (dec.); Anal. Calcd for $\mathrm{C}_{33} \mathrm{H}_{41} \mathrm{BN}_{2} \mathrm{O}: \mathrm{C}, 80.48 ; \mathrm{H}, 8.39 ; \mathrm{N}, 5.69$. Found: C, 80.51; H, 8.61; N, 5.50.

\section{Large Scale Synthesis of 61}

In a glovebox, to $\mathrm{Boc}_{2} \mathrm{O}(327 \mathrm{mg}, 1.50 \mathrm{mmol})$, an aliquot of stock solution $\mathbf{A}$ of boryllithium 35a $(100 \mathrm{mM}, 10.0 \mathrm{~mL}, 1.00 \mathrm{mmol})$ was added at room temperature and the resulting suspension was stirred for $1 \mathrm{~h}$. After solvent was evaporated under reduced pressure, hexane $(100 \mathrm{~mL})$ was add to a residue. The resulting suspension was filtered through a Celite pad, and the residue was washed with hexane. Volatiles were removed from the filtrate and recrystallization from hexane gave pale yellow crystal $(42.4 \mathrm{mg}, 8.7 \%)$. ${ }^{1} \mathrm{H}$ NMR $\left(\mathrm{C}_{6} \mathrm{D}_{6}, 500 \mathrm{MHz}\right) \delta 1.06(\mathrm{~s}, 9 \mathrm{H}), 1.21(\mathrm{~d}, J=7 \mathrm{~Hz}, 12 \mathrm{H}), 1.32(\mathrm{~d}, J=7 \mathrm{~Hz}, 12 \mathrm{H})$, $3.13(\mathrm{sep}, J=7 \mathrm{~Hz}, 4 \mathrm{H}), 6.11(\mathrm{~s}, 2 \mathrm{H}), 7.15(\mathrm{~d}, J=8 \mathrm{~Hz}, 4 \mathrm{H}), 7.22$ (dd, $J=7 \mathrm{~Hz}, 8 \mathrm{~Hz}, 2 \mathrm{H})$; ${ }^{13} \mathrm{C} \mathrm{NMR}\left(\mathrm{C}_{6} \mathrm{D}_{6}, 125 \mathrm{MHz}\right) \delta 24.1\left(\mathrm{CH}_{3}\right), 24.6\left(\mathrm{CH}_{3}\right), 28.2(\mathrm{CH}), 28.8\left(\mathrm{CH}_{3}\right), 78.2\left(4^{\circ}\right)$, $120.2(\mathrm{CH}), 123.4(\mathrm{CH}), 127.8(\mathrm{CH}), 139.0\left(4^{\circ}\right), 145.6\left(4^{\circ}\right), 174.4\left(\mathrm{br}, 4^{\circ}\right) ;{ }^{11} \mathrm{~B}$ NMR $\left(\mathrm{C}_{6} \mathrm{D}_{6}\right.$, $160 \mathrm{MHz}) \delta 19.1$ (brs); IR (KBr): 1690, $\left(\mathrm{CHCl}_{3}\right): 1680 \mathrm{~cm}^{-1}$; mp: 81.9-83.7 ${ }^{\circ} \mathrm{C}$; Anal. calcd. for $\mathrm{C}_{31} \mathrm{H}_{45} \mathrm{BN}_{2} \mathrm{O}_{2}$ : C, 76.22; H, 9.28; N, 5.73. Found: C, 76.07; H, 9.30; N, 5.64.

\section{Large Scale Synthesis of 62}

In a glovebox, to $(\mathrm{PhO})_{2} \mathrm{CO}(321 \mathrm{mg}, 1.50 \mu \mathrm{mol})$, an aliquot of stock solution $\mathbf{A}$ of boryllithium $35 \mathrm{a}(100 \mathrm{mM}, 10.0 \mathrm{~mL}, 1.00 \mathrm{mmol})$ was added at room temperature and the resulting suspension was stirred for $1 \mathrm{~h}$. After solvent was evaporated under reduced pressure, hexane $(300 \mathrm{~mL})$ was add to a residue. The resulting suspension was filtered through a Celite pad, and the residue was washed with hexane. Volatiles were removed from the filtrate and recrystallization from hexane gave colorless crystal $(84.6 \mathrm{mg}, 17 \%)$. ${ }^{1} \mathrm{H}$ NMR $\left(\mathrm{C}_{6} \mathrm{D}_{6}\right) \delta: 1.22(\mathrm{~d}, J=7 \mathrm{~Hz}, 12 \mathrm{H}), 1.30(\mathrm{~d}, J=7 \mathrm{~Hz}, 12 \mathrm{H}), 3.18$ (sep, $J=7 \mathrm{~Hz}$, 4H), $6.17(\mathrm{~s}, 2 \mathrm{H}), 6.72(\mathrm{~d}, J=8 \mathrm{~Hz}, 2 \mathrm{H}), 6.87(\mathrm{t}, J=7 \mathrm{~Hz}, 2 \mathrm{H}), 6.98(\mathrm{t}, J=8 \mathrm{~Hz}, 1 \mathrm{H}), 7.11$ $(\mathrm{d}, J=8 \mathrm{~Hz}, 2 \mathrm{H}), 7.17(\mathrm{~d}, J=7 \mathrm{~Hz}, 2 \mathrm{H}), 7.25(\mathrm{t}, J=8 \mathrm{~Hz}, 2 \mathrm{H}) ;{ }^{13} \mathrm{C}$ NMR $\left(\mathrm{C}_{6} \mathrm{D}_{6}, 125\right.$ MHz) $\delta 24.2\left(\mathrm{CH}_{3}\right), 24.6\left(\mathrm{CH}_{3}\right), 28.9(\mathrm{CH}), 120.7(\mathrm{CH}), 121.9(\mathrm{CH}), 123.6(\mathrm{CH}), 125.1$ $(\mathrm{CH}), 128.2(\mathrm{CH}), 129.2(\mathrm{CH}), 138.3\left(4^{\circ}\right), 145.9\left(4^{\circ}\right), 151.0\left(4^{\circ}\right), 172.5\left(\mathrm{br}, 4^{\circ}\right) ;{ }^{11} \mathrm{~B} \mathrm{NMR}$ $\left(\mathrm{C}_{6} \mathrm{D}_{6}, 160 \mathrm{MHz}\right) \delta 19.3$ (brs) IR (KBr): $1719,\left(\mathrm{CHCl}_{3}\right): 1713 \mathrm{~cm}^{-1} ; \mathrm{mp}: 98.9-100.7{ }^{\circ} \mathrm{C}$; Anal. calcd. for $\mathrm{C}_{33} \mathrm{H}_{41} \mathrm{BN}_{2} \mathrm{O}_{2}$ : C, 77.95; H, 8.13; N, 5.51. Found: C, 77.84; H, 8.31; N, 5.42 .

\section{Large Scale Synthesis of 63a}

In a glovebox, a $25 \mathrm{~mL}$ J-Young tube equipped with a glass stir bar was charged with an aliquot of stock solution A of boryllithium 35a (100 mM, $20.0 \mathrm{~mL}, 2.00 \mathrm{mmol})$. After the J-Young tube was brought out from the glovebox, the solution was freezed in liquid $\mathrm{N}_{2}$ bath and vacuumed. $\mathrm{CO}_{2}$ gas was filled in the J-Young tube at $-78{ }^{\circ} \mathrm{C}$ and the solution was stirred at $-78{ }^{\circ} \mathrm{C}$ for $1 \mathrm{~h}$. After removal of solvent, the J-Young tube was brought into the glovebox. The residue was dissolved in a mixture of hexane and $\mathrm{Et}_{2} \mathrm{O}(9: 1)$. The resulting 
solution was charged on the top of a silica gel column (hexane : $\mathrm{Et}_{2} \mathrm{O}=9: 1$ ) and the product was separated to give a white solid. Analytically pure crystals were obtained from a hexane solution. (692 mg, 80\%). ${ }^{1} \mathrm{H}$ NMR $\left(\mathrm{C}_{6} \mathrm{D}_{6}, 500 \mathrm{MHz}\right) \delta 1.18(\mathrm{~d}, J=7 \mathrm{~Hz}, 12 \mathrm{H}), 1.23$ $(\mathrm{d}, J=7 \mathrm{~Hz}, 12 \mathrm{H}), 3.07(\mathrm{sep}, J=7 \mathrm{~Hz}, 4 \mathrm{H}), 6.06(\mathrm{~s}, 2 \mathrm{H}), 7.11(\mathrm{~d}, J=8 \mathrm{~Hz}, 4 \mathrm{H}), 7.19(\mathrm{t}, J=$ $8 \mathrm{~Hz}, 2 \mathrm{H}), 8.36(\mathrm{br} \mathrm{s}, 1 \mathrm{H}) ;{ }^{13} \mathrm{C}$ NMR $\left(\mathrm{C}_{6} \mathrm{D}_{6}\right) \delta: 24.1\left(\mathrm{CH}_{3}\right), 24.6\left(\mathrm{CH}_{3}\right), 28.7(\mathrm{CH}), 120.7$ $(\mathrm{CH}), 123.5(\mathrm{CH}), 128.1(\mathrm{CH}) 138.1\left(4^{\circ}\right), 145.5\left(4^{\circ}\right), 181.6\left(4^{\circ}\right) ;{ }^{11} \mathrm{~B}$ NMR $\left(\mathrm{C}_{6} \mathrm{D}_{6}, 160\right.$ $\mathrm{MHz}) \delta 19.0$ (brs); IR (KBr): 1666, $\left(\mathrm{CHCl}_{3}\right): 1672,1709 \mathrm{~cm}^{-1}$; mp: 206.2-207.8 ${ }^{\circ} \mathrm{C}$; Anal. calcd. for $\mathrm{C}_{26} \mathrm{H}_{37} \mathrm{BN}_{2} \mathrm{O}$ : C, 75.00; H, 8.62; N, 6.48. Found: C, 74.85; H, 8.62; N, 6.43.

\section{Large Scale Synthesis of 64a}

In a glovebox, a $25 \mathrm{~mL}$ J-Young tube equipped with a glass stir bar was charged with an aliquot of stock solution A of boryllithium 35a (100 mM, $10.0 \mathrm{~mL}, 1.00 \mathrm{mmol})$. After the J-Young tube was brought out from the glovebox, the solution was freezed in liquid $\mathrm{N}_{2}$ bath and vacuumed. $\mathrm{CO}_{2}$ gas was filled in the J-Young tube at $-78{ }^{\circ} \mathrm{C}$ and the solution was stirred at $-78{ }^{\circ} \mathrm{C}$ for $1 \mathrm{~h}$. After removal of solvent, the J-Young tube was brought into the glovebox and hexane $(50 \mathrm{~mL})$ was added to a residue. The resulting suspension was filtered through a pad of Celite, and the residue was washed with hexane. Volatiles were removed from the filtrate and recrystallization from hexane solution to give a colorless crystal. (20.0 $\mathrm{mg}, 4.9 \%) .{ }^{1} \mathrm{H}$ NMR $\left(\mathrm{C}_{6} \mathrm{D}_{6}, 500 \mathrm{MHz}\right) \delta 1.23(\mathrm{~d}, J=7 \mathrm{~Hz}, 12 \mathrm{H}), 1.25(\mathrm{~d}, J=7 \mathrm{~Hz}, 12 \mathrm{H})$, $2.41(\mathrm{~s}, 1 \mathrm{H}), 3.31(\mathrm{sep}, J=7 \mathrm{~Hz}, 4 \mathrm{H}), 5.89(\mathrm{~s}, 2 \mathrm{H}), 7.15(\mathrm{~d}, J=7 \mathrm{~Hz}, 4 \mathrm{H}), 7.22(\mathrm{dd}, J=7$ $\mathrm{Hz}, 8 \mathrm{~Hz}, 2 \mathrm{H}) ;{ }^{13} \mathrm{C}$ NMR $\left(\mathrm{C}_{6} \mathrm{D}_{6}, 125 \mathrm{MHz}\right) \delta 24.1\left(\mathrm{CH}_{3}\right), 24.4\left(\mathrm{CH}_{3}\right), 28.8(\mathrm{CH}), 116.5$ $(\mathrm{CH}), 123.8(\mathrm{CH}), 128.3(\mathrm{CH}), 137.7\left(4^{\circ}\right), 147.2\left(4^{\circ}\right) ;{ }^{11} \mathrm{~B}$ NMR $\left(\mathrm{C}_{6} \mathrm{D}_{6}, 160 \mathrm{MHz}\right) \delta 21.9$ (brs); mp: 186.2-188.8 ${ }^{\circ} \mathrm{C}$; Anal. calcd. for $\mathrm{C}_{26} \mathrm{H}_{37} \mathrm{BN}_{2} \mathrm{O}$ : C, 77.22; H, 9.22; N, 6.93. Found: C, 77.02; H, 9.45; N, 6.67.

\section{Independent Synthesis of 65}

A solution of phenyllithium (in cyclohexane- $\mathrm{Et}_{2} \mathrm{O}, 1.08 \mathrm{M}, 12.0 \mathrm{~mL}, 12.1 \mathrm{mmol}$ ) was added to a hexane solution of $\mathbf{3 4 a - B r}(599 \mathrm{mg}, 1.28 \mathrm{mmol}, 50 \mathrm{~mL})$ under argon atmosphere at room temperature and the resulting solution was stirred at reflux for $12 \mathrm{~h}$. After quenched by ${ }^{i} \mathrm{Pr}_{2} \mathrm{EtNHCl}(2.07 \mathrm{~g}, 12.5 \mathrm{mmol})$, solvent was evaporated under reduced pressure and hexane $(100 \mathrm{~mL})$ was added to a residue. The resulting suspension was filtered through a Celite pad, and the residue was washed with hexane. Volatiles were removed from the filtrate and recrystallization from hexane gave colorless crystal $(476 \mathrm{mg}, 80 \%)$. ${ }^{1} \mathrm{H}$ NMR $\left(\mathrm{C}_{6} \mathrm{D}_{6}\right) \delta: 1.08(\mathrm{~d}, J=7 \mathrm{~Hz}, 12 \mathrm{H}), 1.21(\mathrm{~d}, J=7 \mathrm{~Hz}, 12 \mathrm{H}), 3.30(\mathrm{sep}, J=7 \mathrm{~Hz}, 4 \mathrm{H}), 6.25(\mathrm{~s}$, 2H), 6.79-6.87 (m, 3H), $7.13(\mathrm{~d}, J=7 \mathrm{~Hz}, 2 \mathrm{H}), 7.20(\mathrm{~d}, J=7 \mathrm{~Hz}, 4 \mathrm{H}), 7.27(\mathrm{dd}, J=8,7 \mathrm{~Hz}$, $2 \mathrm{H}) ;{ }^{13} \mathrm{C}$ NMR $\left(\mathrm{C}_{6} \mathrm{D}_{6}, 125 \mathrm{MHz}\right) \delta 23.7\left(\mathrm{CH}_{3}\right), 25.0\left(\mathrm{CH}_{3}\right), 28.7(\mathrm{CH}), 120.3(\mathrm{CH}), 124.2$ $(\mathrm{CH}), 127.7(\mathrm{CH}), 128.1(\mathrm{CH}), 128.6(\mathrm{CH}), 132.7\left(\mathrm{br}, 4^{\circ}\right), 133.6(\mathrm{CH}), 140.2\left(4^{\circ}\right), 146.1$ $\left(4^{\circ}\right) ;{ }^{11} \mathrm{~B}$ NMR $\left(\mathrm{C}_{6} \mathrm{D}_{6}, 160 \mathrm{MHz}\right) \delta 25.0$ (brs) mp: 141.9-144.0 ${ }^{\circ} \mathrm{C}$; Anal. calcd. for $\mathrm{C}_{32} \mathrm{H}_{41} \mathrm{BN}_{2}$ : C, 82.74; H, 8.90; N, 6.03. Found: C, 82.85; H, 9.16; N, 5.82.

\section{Large Scale Synthesis of 66}

In a glovebox, to $\mathrm{C}_{6} \mathrm{~F}_{6}(279 \mathrm{mg}, 1.50 \mu \mathrm{mol})$, an aliquot of stock solution $\mathbf{A}$ of boryllithium 35a $(100 \mathrm{mM}, 10.0 \mathrm{~mL}, 1.00 \mathrm{mmol})$ was added at room temperature and the 
resulting suspension was stirred for $1 \mathrm{~h}$. After solvent was evaporated under reduced pressure, hexane $(100 \mathrm{~mL})$ was add to a residue. The resulting suspension was filtered through a Celite pad, and the residue was washed with hexane. Volatiles were removed from the filtrate and recrystallization from hexane gave colorless crystal $(115 \mathrm{mg}, 21 \%) .{ }^{1} \mathrm{H}$ NMR $\left(\mathrm{C}_{6} \mathrm{D}_{6}\right) \delta: 1.18(\mathrm{~d}, J=7 \mathrm{~Hz}, 12 \mathrm{H}), 1.24(\mathrm{~d}, J=7 \mathrm{~Hz}, 12 \mathrm{H}), 3.17(\mathrm{sep}, J=7 \mathrm{~Hz}, 4 \mathrm{H})$, $6.32(\mathrm{~s}, 2 \mathrm{H}), 7.059(\mathrm{~d}, J=8 \mathrm{~Hz}, 2 \mathrm{H}), 7.061(\mathrm{~d}, J=7 \mathrm{~Hz}, 2 \mathrm{H}), 7.12(\mathrm{dd}, J=8,7 \mathrm{~Hz}, 2 \mathrm{H})$; ${ }^{13} \mathrm{C} \mathrm{NMR}\left(\mathrm{C}_{6} \mathrm{D}_{6}, 125 \mathrm{MHz}\right) \delta 23.2\left(\mathrm{CH}_{3}\right), 26.4\left(\mathrm{CH}_{3}\right), 28.6(\mathrm{CH}), 105.8\left(\mathrm{br}, 4^{\circ}\right), 121.2(\mathrm{CH})$, $123.9(\mathrm{CH}), 128.4(\mathrm{CH}), 137.4\left(\mathrm{~d}, J=250 \mathrm{~Hz}, 4^{\circ}\right), 137.5\left(4^{\circ}\right), 141.7\left(\mathrm{~d}, J=253 \mathrm{~Hz}, 4^{\circ}\right)$, $146.4\left(4^{\circ}\right), 147.7\left(\mathrm{~d}, J=242 \mathrm{~Hz}, 4^{\circ}\right) ;{ }^{11} \mathrm{~B}$ NMR $\left(\mathrm{C}_{6} \mathrm{D}_{6}, 160 \mathrm{MHz}\right) \delta 22.5(\mathrm{brs}) ;{ }^{19} \mathrm{~F}$ NMR $\left(\mathrm{C}_{6} \mathrm{D}_{6}, 470 \mathrm{MHz}\right) \delta:-130.5(\mathrm{~d}, J=12 \mathrm{~Hz}, 2 \mathrm{~F}),-151.4(\mathrm{t}, J=23 \mathrm{~Hz}, 1 \mathrm{~F}),-162.2(\mathrm{dt}, J=12$ $\mathrm{Hz}, 23 \mathrm{~Hz}, 2 \mathrm{~F})$; mp: $156.0-157.0{ }^{\circ} \mathrm{C}$; Anal. calcd. for $\mathrm{C}_{32} \mathrm{H}_{36} \mathrm{BN}_{2} \mathrm{~F}_{5}: \mathrm{C}, 69.32 ; \mathrm{H}, 6.54 ; \mathrm{N}$, 5.05. Found: C, 69.60; H, 6.67; N, 4.96.

\section{Large Scale Synthesis of 60b}

In a glovebox, the THF solution of benzoyl chloride (141 mg, $1.35 \mathrm{mmol}, 1 \mathrm{~mL}$ THF) was added to the stock solution $\mathbf{B}$ of boryllithium $35 \mathbf{b}(75.0 \mathrm{mM}, 16.4 \mathrm{ml}, 1.23 \mathrm{mmol})$, the filtrate was added at $-45{ }^{\circ} \mathrm{C}$ and the resulting suspension was stirred for $1 \mathrm{~h}$ at room temperature. After solvents were evaporated under reduced pressure, the residue was purified by silica gel column chromatography (hexane : dichloromethane $=3: 1$ ) to give a white solid $(173 \mathrm{mg}, 28 \%)$. ${ }^{1} \mathrm{H}$ NMR $\left(\mathrm{C}_{6} \mathrm{D}_{6}\right) \delta: 1.28(\mathrm{~d}, J=7 \mathrm{~Hz}, 12 \mathrm{H}), 1.30(\mathrm{~d}, J=7 \mathrm{~Hz}$, $12 \mathrm{H}), 3.62(\mathrm{~s}, 4 \mathrm{H}), 3.81(\mathrm{sep}, J=7 \mathrm{~Hz}, 4 \mathrm{H}), 6.90-7.05(\mathrm{~m}, 9 \mathrm{H}), 7.89$ (dt, $J=8 \mathrm{~Hz}, 1 \mathrm{~Hz}$, $2 \mathrm{H}) ;{ }^{13} \mathrm{C}$ NMR $\left(\mathrm{C}_{6} \mathrm{D}_{6}, 125 \mathrm{MHz}\right) \delta 26.3\left(\mathrm{CH}_{3}\right), 26.3\left(\mathrm{CH}_{3}\right), 28.7(\mathrm{CH}), 54.1(\mathrm{CH}), 124.2$ $(\mathrm{CH}), 127.4(\mathrm{CH}), 128.3(\mathrm{CH}), 128.5(\mathrm{CH}), 132.7(\mathrm{CH}), 138.5\left(4^{\circ}\right), 140.1\left(4^{\circ}\right), 147.3\left(4^{\circ}\right)$, 221.0 (br, $\left.4^{\circ}\right) ;{ }^{11} \mathrm{~B}$ NMR $\left(\mathrm{C}_{6} \mathrm{D}_{6}, 160 \mathrm{MHz}\right) \delta 27.4$ (brs), IR (KBr): 1638, $\left(\mathrm{CHCl}_{3}\right): 1638 \mathrm{~cm}^{-}$ ; mp: 120.0-123.8 ${ }^{\circ} \mathrm{C}$ (dec); Anal. calcd. for $\mathrm{C}_{33} \mathrm{H}_{43} \mathrm{BN}_{2} \mathrm{O}: \mathrm{C}, 80.15 ; \mathrm{H}, 8.76 ; \mathrm{N}, 5.66$. Found: C, 79.90; H, 9.00; N, 5.66.

\section{Independent Synthesis of 64b}

$\mathrm{CsOH}(277 \mathrm{mg}, 1.85 \mathrm{mmol}$ ) was added to the hexane solution of 34b (488 $\mathrm{mg}, 1.04$ mmol) under argon atmosphere at room temperature and the resulting solution was stirred at room temperature for $3 \mathrm{~h}$. After solvent was evaporated under reduced pressure, hexane $(50 \mathrm{~mL})$ was added to a residue. The resulting suspension was filtered through a Celite pad, and the residue was washed with hexane. Volatiles were removed from the filtrate and recrystallization from hexane gave colorless crystal $(339 \mathrm{mg}, 68 \%) .{ }^{1} \mathrm{H}$ NMR $\left(\mathrm{C}_{6} \mathrm{D}_{6}\right) \delta$ : $1.28(\mathrm{~d}, J=7 \mathrm{~Hz}, 12 \mathrm{H}), 1.29(\mathrm{~d}, J=7 \mathrm{~Hz}, 12 \mathrm{H}), 2.31(\mathrm{~s}, 1 \mathrm{H}), 3.39(\mathrm{~s}, 4 \mathrm{H}), 3.53(\mathrm{sep}, J=7$ $\mathrm{Hz}, 4 \mathrm{H}), 7.111(\mathrm{~d}, J=8 \mathrm{~Hz}, 2 \mathrm{H}), 7.112(\mathrm{~d}, J=7 \mathrm{~Hz}, 2 \mathrm{H}), 7.17(\mathrm{dd}, J=8,6 \mathrm{~Hz}, 2 \mathrm{H}) ;{ }^{13} \mathrm{C}$ $\operatorname{NMR}\left(\mathrm{C}_{6} \mathrm{D}_{6}, 125 \mathrm{MHz}\right) \delta 24.4\left(\mathrm{CH}_{3}\right), 25.2\left(\mathrm{CH}_{3}\right), 28.7(\mathrm{CH}), 50.9\left(\mathrm{CH}_{2}\right), 124.1(\mathrm{CH}), 127.1$ $(\mathrm{CH}), 139.2\left(4^{\circ}\right), 148.5\left(4^{\circ}\right) ;{ }^{11} \mathrm{~B}$ NMR $\left(\mathrm{C}_{6} \mathrm{D}_{6}, 160 \mathrm{MHz}\right) \delta 24.2$ (brs) mp: $189.8-190.7{ }^{\circ} \mathrm{C}$; Anal. calcd. for $\mathrm{C}_{26} \mathrm{H}_{39} \mathrm{BN}_{2} \mathrm{O}$ : C, 76.84; H, 9.67; N, 6.89. Found: C, 76.73; H, 9.82; N, 6.70. 


\section{X-ray Crystallography}

Details of the crystal data and a summary of the intensity data collection parameters for 34a-Br, 34a-I, 34b, (35a-DME) $)_{2}, 35 a \cdot(T H F)_{2}, 35 b \cdot(T H F)_{2}, 35 c \cdot(T H F)_{2}, 38 a, 38 b, 38 c, 55$, $57,58,60 a, 60 b, 61,62,64 a$, and 65 are listed in Table S1. In each case a suitable crystal was mounted with a mineral oil to the glass fiber and transferred to the goniometer of a Rigaku Mercury CCD diffractometer with graphite-monochromated Mo $\mathrm{K} \alpha$ radiation $(\lambda=$ $0.71069 \AA$ ). The structures were solved by direct methods with (SIR-97) ${ }^{8}$ and refined by full-matrix least-squares techniques against $F^{2}$ (SHELXL-97). ${ }^{9}$ The intensities were corrected for Lorentz and polarization effects. The non-hydrogen atoms were refined anisotropically. Hydrogen atoms were refined isotropically in the difference Fourier maps or placed using AFIX instructions. 
Table S1. Crystallographic data and structure refinement details for 34a-Br, 34a-I, 34b, (35a-DME) $35 \mathrm{a} \cdot(\mathrm{THF})_{2}, 35 \mathrm{~b} \cdot(\mathrm{THF})_{2}, 35 \mathrm{c} \cdot(\mathrm{THF})_{2}, 38 \mathrm{a}, 38 \mathrm{~b}, 38 \mathrm{c}, 55,57,58,60 \mathrm{a}, 60 \mathrm{~b}, 61,62,64 \mathrm{a}$, and 65

\begin{tabular}{|c|c|c|c|c|c|}
\hline & $34 \mathrm{a}-\mathrm{Br}$ & 34a-I & $34 b$ & $(35 \mathrm{a} \cdot \mathrm{DME})_{2}$ & $35 \mathrm{a} \cdot(\mathrm{THF})_{2}$ \\
\hline formula & $\mathrm{C}_{26} \mathrm{H}_{36} \mathrm{BBrN}_{2}$ & $\mathrm{C}_{26} \mathrm{H}_{36} \mathrm{BIN}_{2}$ & $\mathrm{C}_{26} \mathrm{H}_{38} \mathrm{BBrN}_{2}$ & $\mathrm{C}_{30} \mathrm{H}_{46} \mathrm{BLiN}_{2} \mathrm{O}_{2}$ & $\mathrm{C}_{34} \mathrm{H}_{52} \mathrm{BLiN}_{2} \mathrm{O}_{2}$ \\
\hline fw & 467.29 & 514.28 & 455.29 & 484.44 & 538.53 \\
\hline $\mathrm{T}(\mathrm{K})$ & $120(2)$ & $120(2)$ & $103(2)$ & $103(2)$ & $103(2)$ \\
\hline$\lambda(\AA)$ & 0.71070 & 0.71070 & $0.71070 \AA$ & 0.71070 & 0.71070 \\
\hline cryst syst & Monoclinic & Triclinic & Monoclinic & Orthorhombic & Orthorhombic \\
\hline space group & $P 2_{1} / n$ & $P-1$ & $P 2_{1} / n$ & Pbca & Pbca \\
\hline$a,(\AA)$ & $19.153(12)$ & $7.4883(2)$ & $19.222(14)$ & $17.0118(11)$ & $11.5625(10)$ \\
\hline$b,(\AA)$ & $6.945(4)$ & $9.48350(10)$ & $6.924(5)$ & $19.5103(11)$ & $19.603(2)$ \\
\hline$c,(\AA)$ & $19.384(13)$ & $18.5512(4)$ & $19.362(14)$ & $18.3570(11)$ & $28.941(2)$ \\
\hline$\alpha,(\mathrm{deg})$ & 90 & $77.6015(8)$ & 90 & 90 & 90 \\
\hline$\beta,(\operatorname{deg})$ & $105.996(9)$ & $86.8095(12)$ & $105.271(3)$ & 90 & 90 \\
\hline$\gamma,(\operatorname{deg})$ & 90 & $80.4265(12)$ & 90 & 90 & 90 \\
\hline$V,\left(\AA^{3}\right)$ & $2478(3)$ & $1268.50(5)$ & $2486(3)$ & $6092.8(6)$ & $6559.9(10)$ \\
\hline$Z$ & 4 & 2 & 4 & 8 & 8 \\
\hline$D_{\text {calc }},\left(\mathrm{g} / \mathrm{cm}^{3}\right)$ & 1.252 & 1.346 & 1.217 & 1.056 & 1.091 \\
\hline$\mu\left(\mathrm{mm}^{-1}\right)$ & 1.673 & 1.277 & 1.665 & 0.064 & 0.065 \\
\hline $\mathrm{F}(000)$ & 984 & 528 & 964 & 2112 & 2352 \\
\hline cryst size $(\mathrm{mm})$ & $0.50 \times 0.50 \times 0.10$ & $0.60 \times 0.50 \times 0.20$ & $0.60 \times 0.50 \times 0.20$ & $0.60 \times 0.50 \times 0.25$ & $0.60 \times 0.60 \times 0.50$ \\
\hline $2 \theta$ range, $(\mathrm{deg})$ & $3.13-25.00$ & $2.23-25.00$ & $3.14-25.00$ & $1.94-25.00$ & $3.07-25.00$ \\
\hline reflns collected & 22348 & 12253 & 20953 & 36996 & 47794 \\
\hline indep reflns $/ R_{\text {int }}$ & $4353 / 0.0785$ & $4350 / 0.0128$ & $4369 / 0.0710$ & $5355 / 0.0460$ & $5758 / 0.0823$ \\
\hline params & 279 & 279 & 279 & 155 & 369 \\
\hline GOF on $F^{2}$ & 1.099 & 1.106 & 1.111 & 1.071 & 1.223 \\
\hline$R_{1}, \mathrm{w} R_{2}[\mathrm{I}>2 \sigma(\mathrm{I})]$ & $0.0912,0.2386$ & $0.0165,0.0421$ & $0.0647,0.1569$ & $0.0814,0.2329$ & $0.0874,0.1634$ \\
\hline$R_{1}, \mathrm{w} R_{2}$ (all data) & $0.1086,0.2570$ & $0.0168,0.0423$ & $0.0688,0.1599$ & $0.1036,0.2575$ & $0.0892,0.1642$ \\
\hline
\end{tabular}




\begin{tabular}{llllll}
\hline & $\mathbf{3 5 b} \cdot(\mathbf{T H F})_{2}$ & $\mathbf{3 5 c} \cdot(\mathbf{T H F})_{2}$ & $\mathbf{3 8 a}$ & $\mathbf{3 8 b}$ & $\mathbf{3 8 c}$ \\
\hline formula & $\mathrm{C}_{34} \mathrm{H}_{54} \mathrm{BN}_{2} \mathrm{O}_{2}$ & $\mathrm{C}_{38} \mathrm{H}_{54} \mathrm{BLiN}_{2} \mathrm{O}_{2}$ & $\mathrm{C}_{26} \mathrm{H}_{37} \mathrm{BN}_{2}$ & $\mathrm{C}_{26} \mathrm{H}_{39} \mathrm{BN}_{2}$ & $\mathrm{C}_{30} \mathrm{H}_{39} \mathrm{BN}_{2}$ \\
$\mathrm{fw}$ & 540.54 & 588.58 & 388.39 & 390.40 & 438.44 \\
$\mathrm{~T}(\mathrm{~K})$ & $103(2)$ & $103(2)$ & $120(2)$ & $103(2)$ & $103(2)$ \\
$\lambda(\AA)$ & 0.71070 & 0.71070 & 0.71070 & 0.71070 & 0.71070 \\
cryst syst & Orthorhombic & Monoclinic & Orthorhombic & Orthorhombic & Triclinic \\
space group & $P b c n$ & $C 2 / c$ & $P c c n$ & $P c c n$ & $P-1$ \\
$a,(\AA)$ & $12.580(3)$ & $11.190(11)$ & $18.891(5)$ & $19.035(9)$ & $10.450(6)$ \\
$b,(\AA)$ & $16.395(4)$ & $17.754(17)$ & $15.567(4)$ & $15.165(7)$ & $12.028(9)$ \\
$c,(\AA)$ & $16.766(4)$ & $18.410(18)$ & $16.711(5)$ & $16.723(7)$ & $12.684(7)$ \\
$\alpha,($ deg $)$ & 90 & 90 & 90 & 90 & $69.23(5)$ \\
$\beta,($ deg $)$ & 90 & $99.290(6)$ & 90 & 90 & $67.00(5)$ \\
$\gamma,($ deg $)$ & 90 & 90 & 90 & 90 & $75.57(6)$ \\
$V,\left(\AA^{3}\right)$ & $34579(15)$ & $3610(6)$ & $4914(2)$ & $4970(4)$ & $1360.6(15)$ \\
$Z$ & 4 & 4 & 8 & 8 & 2 \\
$\left.\mathrm{D}_{\text {calc }},(\mathrm{g} / \mathrm{cm})^{3}\right)$ & 1.038 & 1.083 & 1.050 & 1.043 & 1.070 \\
$\left.\mu(\mathrm{mm})^{-1}\right)$ & 0.062 & 0.065 & 0.060 & 0.059 & 0.061 \\
$\mathrm{~F}(000)$ & 1184 & 1280 & 1696 & 1712 & 476 \\
cryst size $(\mathrm{mm})$ & $0.50 \times 0.50 \times 0.40$ & $0.30 \times 0.20 \times 0.10$ & $0.50 \times 0.45 \times 0.30$ & $0.70 \times 0.25 \times 0.15$ & $0.55 \times 0.50 \times 0.40$ \\
$2 \theta$ range, $(\mathrm{deg})$ & $3.17-25.00$ & $3.21-25.00$ & $3.08-25.00$ & $3.07-25.00$ & $3.24-25.00$ \\
reflns collected & 21152 & 11712 & 30228 & 29906 & 8742 \\
indep reflns $/ R_{\text {int }}$ & $3036 / 0.0291$ & $3170 / 0.0521$ & $4302 / 0.0284$ & $4144 / 0.0395$ & $4669 / 0.0350$ \\
params & 186 & 205 & 278 & 335 & 310 \\
$\mathrm{GOF}$ on $F^{2}$ & 1.139 & 1.155 & 1.067 & 1.276 & 1.038 \\
$R_{1}, \mathrm{w} R_{2}[\mathrm{I}>2 \sigma(\mathrm{I})]$ & $0.0481,0.1140$ & $0.0829,0.1853$ & $0.0638,0.1550$ & $0.0690,0.1372$ & $0.0629,0.1622$ \\
$R_{1}, \mathrm{w} R_{2}($ all data) $)$ & $0.0530,0.1169$ & $0.1072,0.1993$ & $0.0717,0.1633$ & $0.0780,0.1411$ & $0.0834,0.1813$ \\
\hline
\end{tabular}




\begin{tabular}{llllll}
\hline & $\mathbf{5 5}$ & $\mathbf{5 7}$ & $\mathbf{5 8}$ & $\mathbf{6 0 a}$ & $\mathbf{6 0 b}$ \\
\hline formula & $\mathrm{C}_{27} \mathrm{H}_{39} \mathrm{BN}_{2}$ & $\mathrm{C}_{33} \mathrm{H}_{43} \mathrm{BN}_{2}$ & $\mathrm{C}_{33} \mathrm{H}_{43} \mathrm{BN}_{2} \mathrm{O}$ & $\mathrm{C}_{33} \mathrm{H}_{41} \mathrm{BN}_{2} \mathrm{O}$ & $\mathrm{C}_{33} \mathrm{H}_{43} \mathrm{BN}_{2} \mathrm{O}$ \\
$\mathrm{fw}$ & 402.41 & 478.50 & 494.50 & 492.49 & 494.50 \\
$\mathrm{~T}(\mathrm{~K})$ & $120(2)$ & $103(2)$ & $103(2)$ & $103(2)$ & $103(2)$ \\
$\lambda(\AA)$ & 0.71070 & 0.71070 & 0.71070 & 0.71070 & 0.71070 \\
cryst syst & Triclinic & Orthorhombic & Orthorhombic & Monoclinic & Triclinic \\
space group & $P-1$ & $P 2_{1} 2_{1} 2_{1}$ & $P{ }_{1} 2_{1} 2_{1}$ & $P 2_{1} / a$ & $P-1$ \\
$a,(\AA)$ & $7.413(5)$ & $12.099(4)$ & $12.205(3)$ & $12.660(6)$ & $9.294(4)$ \\
$b,(\AA)$ & $9.362(7)$ & $13.535(4)$ & $13.677(3)$ & $15.480(8)$ & $11.154(4)$ \\
$c,(\AA)$ & $18.458(14)$ & $18.125(6)$ & $17.907(4)$ & $14.755(7)$ & $14.663(6)$ \\
$\alpha,($ deg $)$ & $77.366(18)$ & 90 & 90 & 90 & $81.830(11)$ \\
$\beta,($ deg $)$ & $86.92(2)$ & 90 & 90 & $90.479(2)$ & $82.698(11)$ \\
$\gamma,($ deg $)$ & $77.526(19)$ & 90 & 90 & 90 & $85.549(11)$ \\
$V,\left(\AA^{3}\right)$ & $1220.5(15)$ & $2968.1(17)$ & $2989.3(12)$ & $2892(2)$ & $1489.8(10)$ \\
$Z$ & 2 & 4 & 4 & 4 & 2 \\
$\left.\mathrm{D}_{\text {calc }},(\mathrm{g} / \mathrm{cm})^{3}\right)$ & 1.095 & 1.071 & 1.099 & 1.131 & 1.102 \\
$\left.\mu(\mathrm{mm})^{-1}\right)$ & 0.062 & 0.061 & 0.065 & 0.067 & 0.065 \\
$\mathrm{~F}(000)$ & 440 & 1040 & 1072 & 1064 & 536 \\
cryst size $(\mathrm{mm})$ & $0.35 \times 0.25 \times 0.05$ & $0.60 \times 0.50 \times 0.30$ & $0.60 \times 0.45 \times 0.30$ & $0.60 \times 0.45 \times 0.25$ & $0.55 \times 0.40 \times 0.20$ \\
$2 \theta$ range, $(\mathrm{deg})$ & $3.03-24.95$ & $3.01-26.49$ & $3.19-27.00$ & $3.06-25.00$ & $3.16-25.00$ \\
reflns collected & 7891 & 21720 & 22778 & 18257 & 9800 \\
indep reflns $/ R_{\text {int }}$ & $4168 / 0.0454$ & $3427 / 0.0236$ & $3653 / 0.0314$ & $4990 / 0.0414$ & $5115 / 0.0300$ \\
params & 280 & 333 & 354 & 342 & 342 \\
$\mathrm{GOF}$ on $F^{2}$ & 1.107 & 1.081 & 1.086 & 1.122 & 1.074 \\
$R_{1}, \mathrm{w} R_{2}[\mathrm{I}>2 \sigma(\mathrm{I})]$ & $0.0925,0.2483$ & $0.0351,0.0841$ & $0.0402,0.1034$ & $0.0572,0.1295$ & $0.0554,0.1337$ \\
$R_{1}, \mathrm{w} R_{2}($ all data $)$ & $0.1329,0.2771$ & $0.0363,0.0849$ & $0.0419,0.1051$ & $0.0782,0.1415$ & $0.0825,0.1498$ \\
\hline
\end{tabular}




\begin{tabular}{lllll}
\hline & $\mathbf{6 1}$ & $\mathbf{6 2}$ & $\mathbf{6 4 a}$ & $\mathbf{6 5}$ \\
\hline formula & $\mathrm{C}_{31} \mathrm{H}_{45} \mathrm{BN}_{2} \mathrm{O}_{2}$ & $\mathrm{C}_{33} \mathrm{H}_{41} \mathrm{BN}_{2} \mathrm{O}_{2}$ & $\mathrm{C}_{26} \mathrm{H}_{37} \mathrm{BN}_{2} \mathrm{O}$ & $\mathrm{C}_{32} \mathrm{H}_{41} \mathrm{BN}_{2}$ \\
$\mathrm{fw}$ & 488.50 & 508.49 & 404.39 & 464.48 \\
$\mathrm{~T}(\mathrm{~K})$ & $103(2)$ & $103(2)$ & $103(2)$ & $103(2)$ \\
$\lambda(\AA)$ & 0.71070 & 0.71070 & 0.71070 & 0.71070 \\
cryst syst & Monoclinic & Triclinic & Orthorhombic & Monoclinic \\
space group & $P{ }_{1} / n$ & $P-1$ & $P c c n$ & $P 2_{1} / c$ \\
$a,(\AA)$ & $9.300(3)$ & $9.474(4)$ & $18.522(4)$ & $13.378(10)$ \\
$b,(\AA)$ & $12.312(4)$ & $10.358(5)$ & $15.505(4)$ & $12.642(9)$ \\
$c,(\AA)$ & $25.655(8)$ & $16.620(9)$ & $16.871(4)$ & $16.528(11)$ \\
$\alpha,($ deg $)$ & 90 & $81.12(3)$ & 90 & 90 \\
$\beta,($ deg $)$ & $94.2715(14)$ & $74.61(3)$ & 90 & $95.338(5)$ \\
$\gamma,($ deg $)$ & 90 & $71.70(2)$ & 90 & 90 \\
$V,\left(\AA^{3}\right)$ & $2929.3(16)$ & $1488.5(13)$ & $4845(2)$ & $2783(3)$ \\
$Z$ & 4 & 2 & 8 & 4 \\
$\left.\mathrm{D}_{\text {calc }},(\mathrm{g} / \mathrm{cm})^{3}\right)$ & 1.108 & 1.135 & 1.109 & 1.108 \\
$\left.\mu(\mathrm{mm})^{-1}\right)$ & 0.068 & 0.069 & 0.066 & 0.063 \\
$\mathrm{~F}(000)$ & 1064 & 548 & 1760 & 1008 \\
cryst size $(\mathrm{mm})$ & $0.60 \times 0.30 \times 0.25$ & $0.40 \times 0.30 \times 0.15$ & $0.50 \times 0.50 \times 0.35$ & $0.50 \times 0.30 \times 0.25$ \\
$2 \theta$ range, $(\mathrm{deg})$ & $3.09-25.00$ & $3.03-25.00$ & $3.09-25.00$ & $3.03-25.00$ \\
reflns collected & 18381 & 9725 & 28956 & 17819 \\
indep reflns $/ R_{\text {int }}$ & $5201 / 0.0348$ & $5105 / 0.0318$ & $4024 / 0.0509$ & $4879 / 0.0370$ \\
params & 336 & 351 & 301 & 324 \\
$\mathrm{GOF}$ on $F^{2}$ & 1.189 & 1.154 & 1.287 & 1.108 \\
$R_{1}, \mathrm{w} R_{2}[\mathrm{I}>2 \sigma(\mathrm{I})]$ & $0.0559,0.1134$ & $0.0653,0.1472$ & $0.0725,0.1389$ & $0.0498,0.1071$ \\
$R_{1}, \mathrm{w} R_{2}(\mathrm{all} \mathrm{data})$ & $0.0641,0.1173$ & $0.0949,0.1659$ & $0.0796,0.1420$ & $0.0633,0.1137$ \\
\hline & & & &
\end{tabular}


Figure S1. ORTEP drawing of 34a-Br with 50\% thermal ellipsoid (All hydrogen atoms were omitted for clarity.)

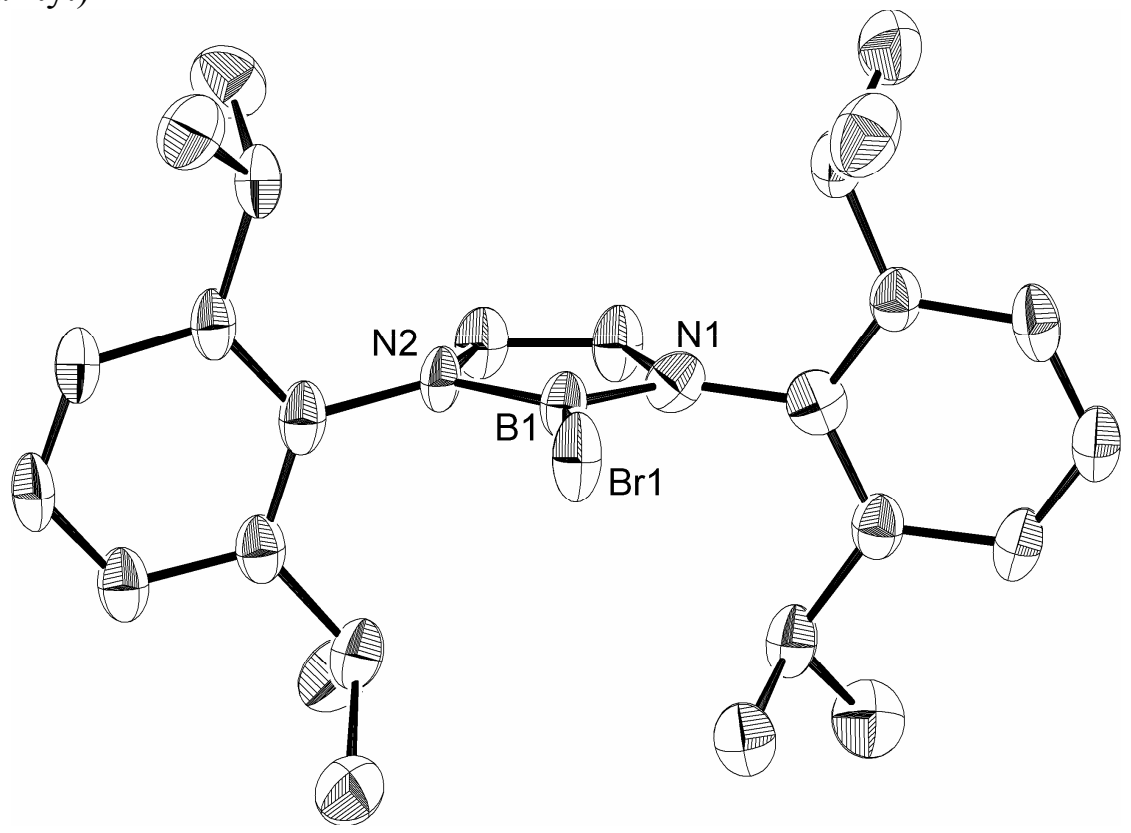

Figure S2. ORTEP drawing of 34a-I with 50\% thermal ellipsoid (All hydrogen atoms were omitted for clarity.)

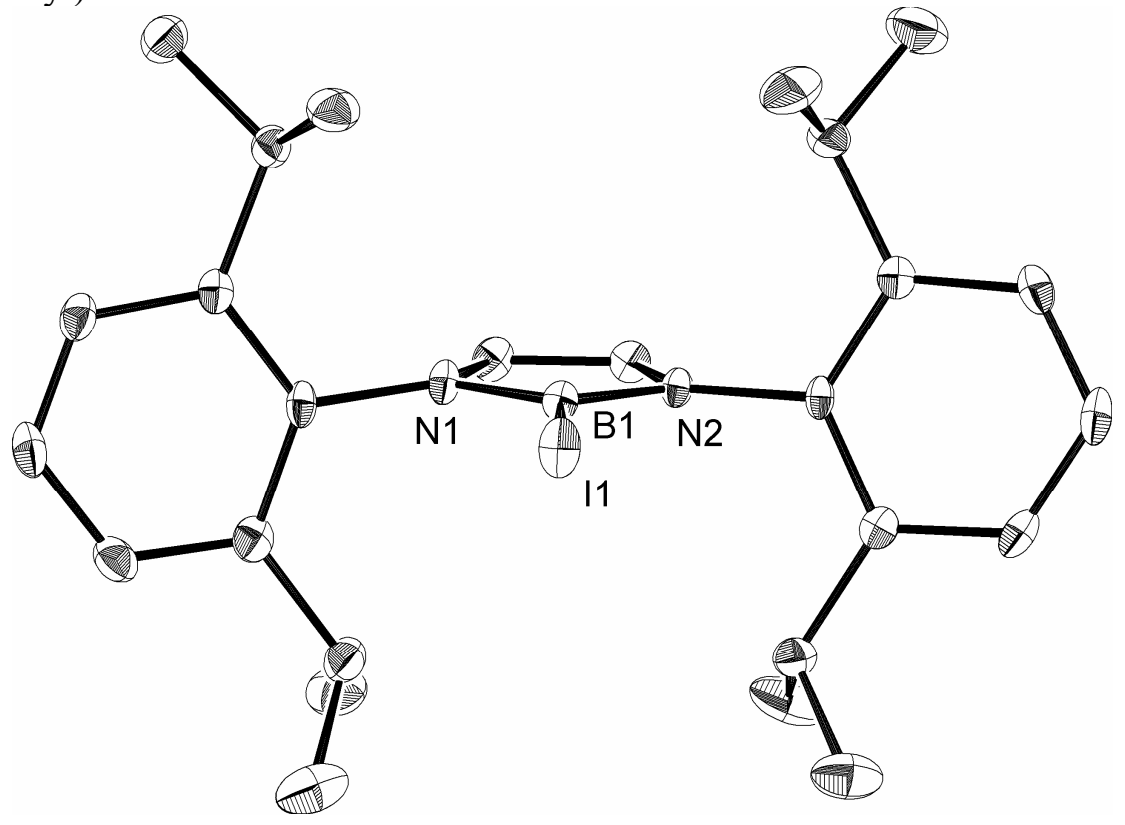


Figure S3. ORTEP drawing of 34b with $50 \%$ thermal ellipsoid (All hydrogen atoms were omitted for clarity.)

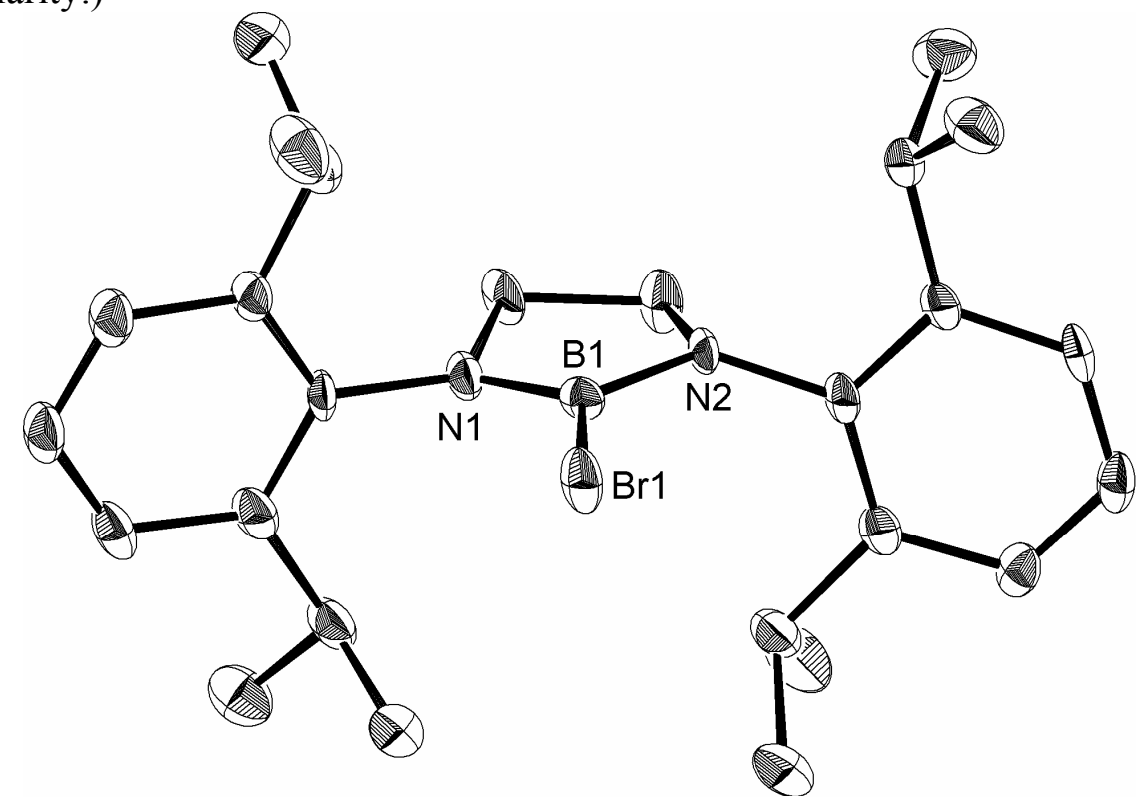

Figure S4. ORTEP drawing of 38a with 50\% thermal ellipsoid (All hydrogen atoms except the hydrogen atom on the boron atom and minor parts of disordered isopropyl groups were omitted for clarity.)

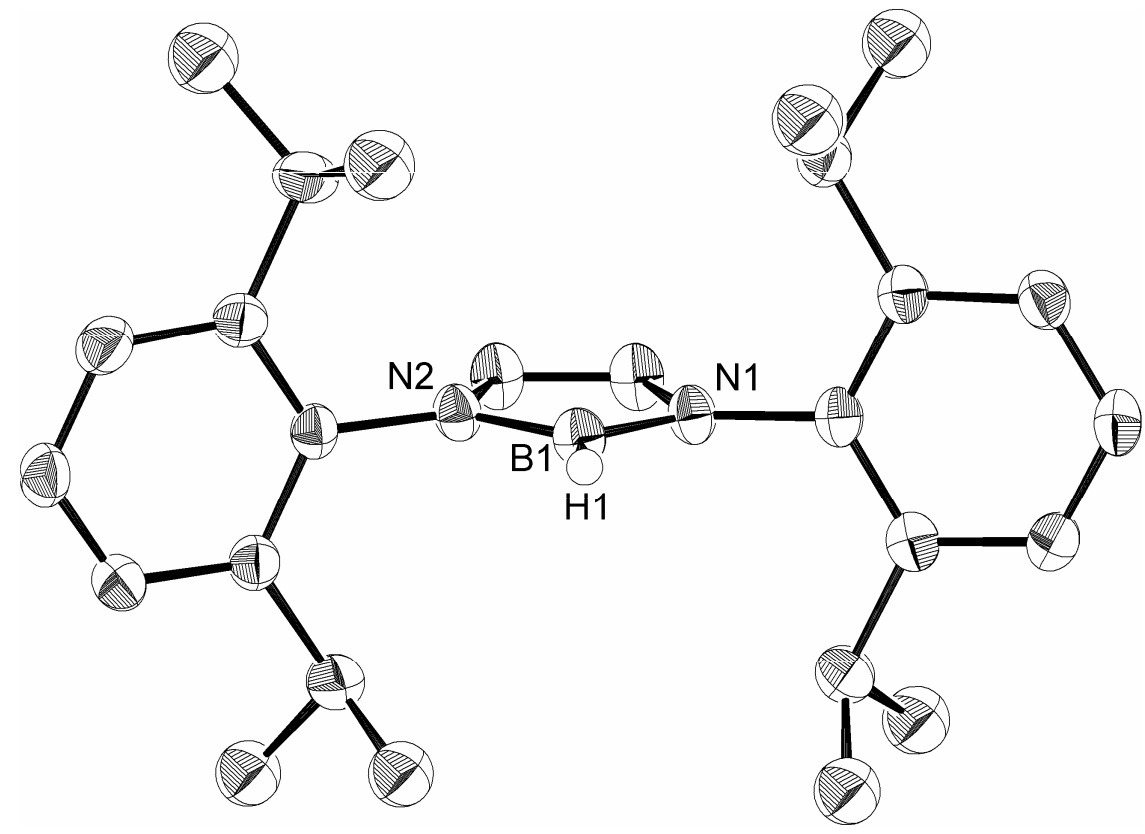


Figure S5. ORTEP drawing of $\mathbf{3 8 b}$ with 50\% thermal ellipsoid (All hydrogen atoms except the hydrogen atom on the boron atom and minor parts of disordered isopropyl groups were omitted for clarity.)

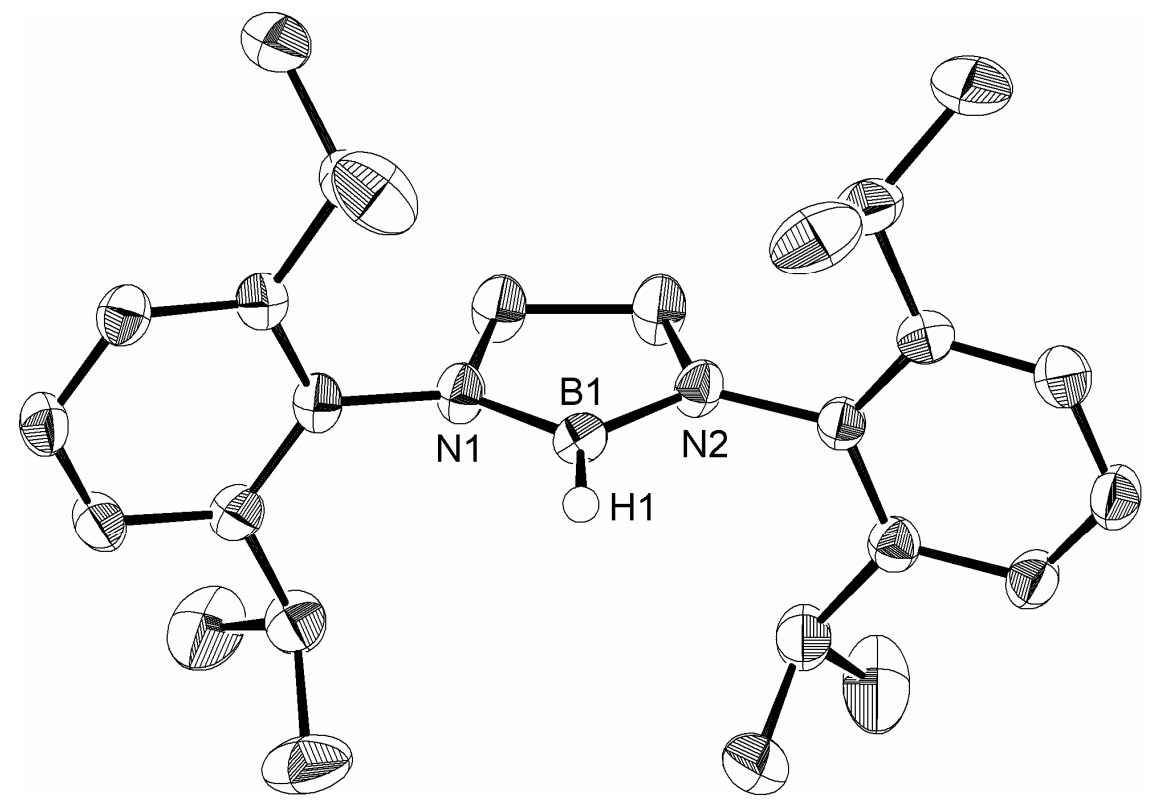

Figure S6. ORTEP drawing of 38c with 50\% thermal ellipsoid (All hydrogen atoms except the hydrogen atom on the boron atom were omitted for clarity.)

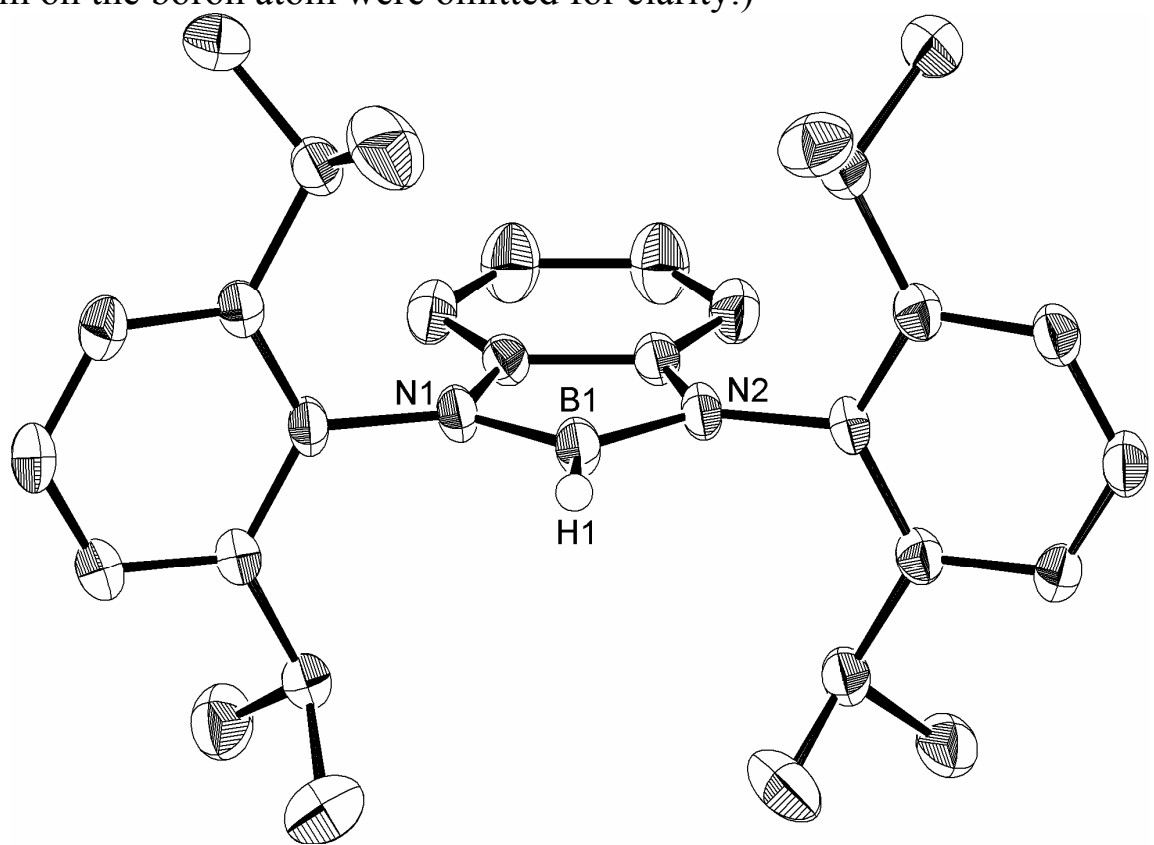


Figure S7. ORTEP drawing of $\mathbf{5 5}$ with 50\% thermal ellipsoid (All hydrogen atoms were omitted for clarity.)

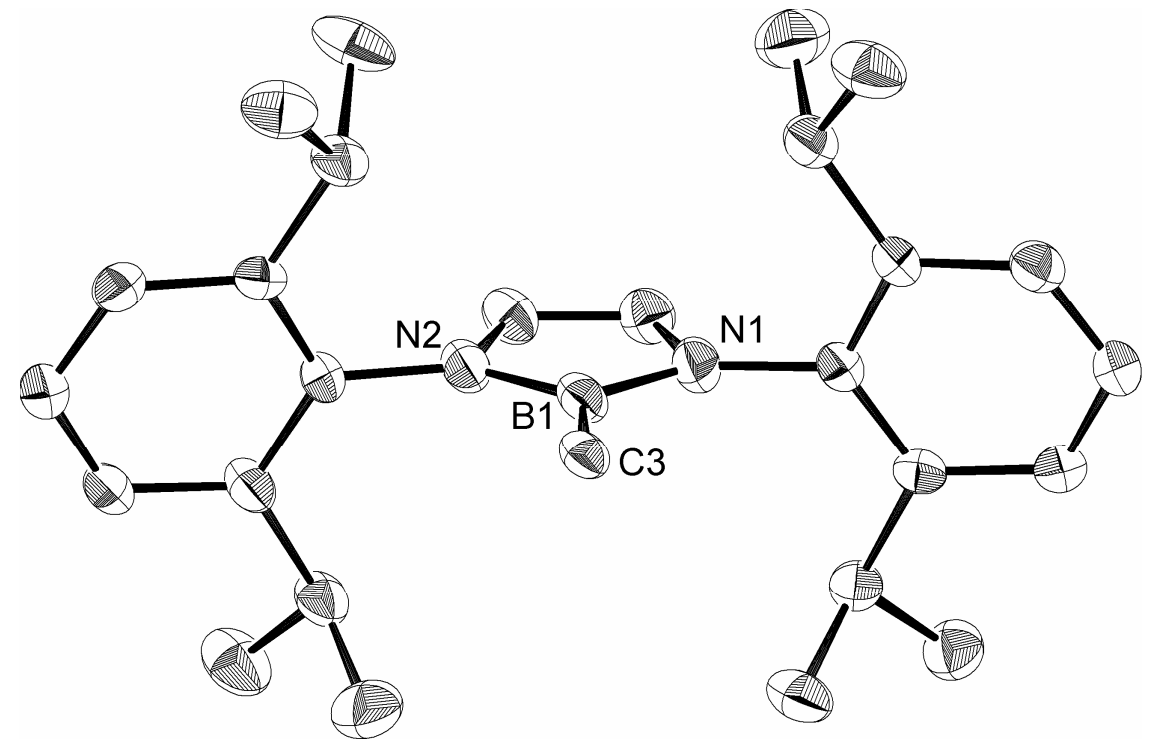

Figure S8. ORTEP drawing of $\mathbf{5 7}$ with 50\% thermal ellipsoid (All hydrogen atoms were omitted for clarity.)

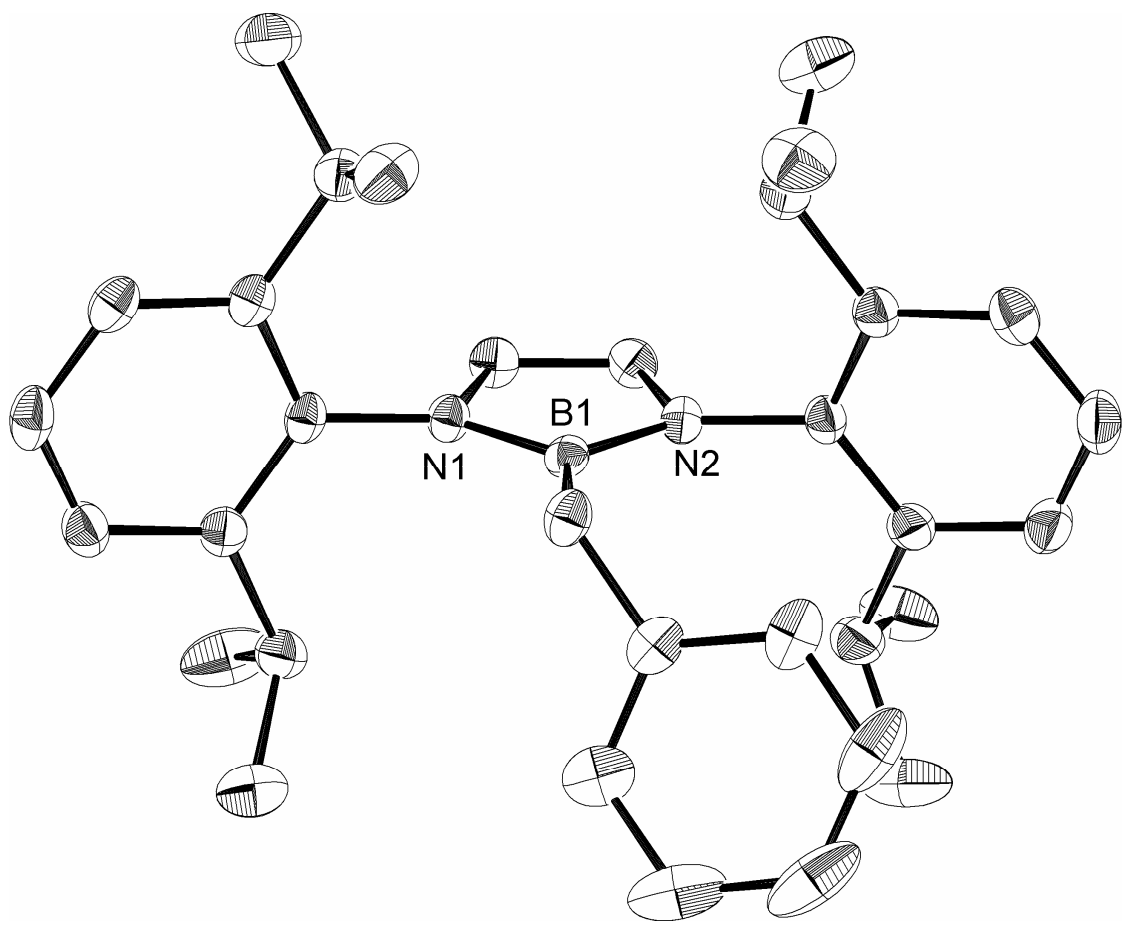


Figure S9. ORTEP drawing of $60 \mathrm{~b}$ with $50 \%$ thermal ellipsoid (All hydrogen atoms were omitted for clarity.)

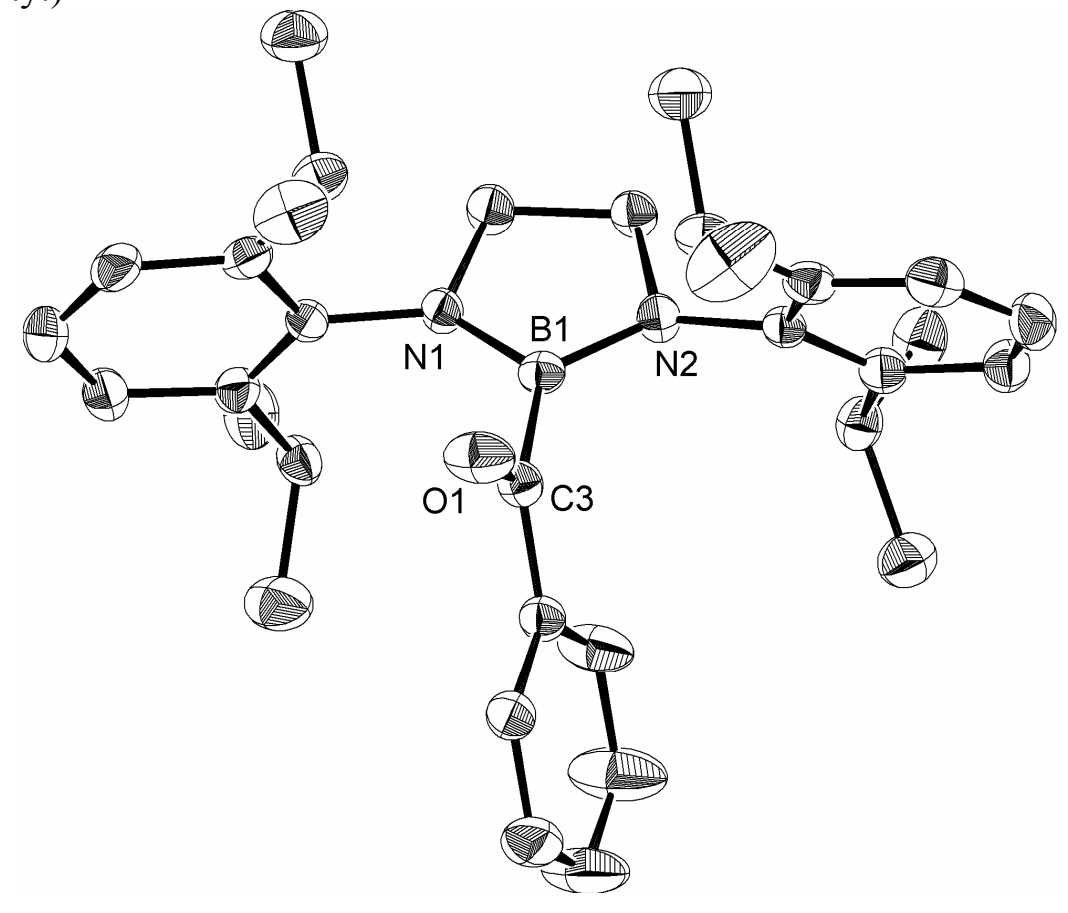

Figure S10. ORTEP drawing of $\mathbf{6 1}$ with $50 \%$ thermal ellipsoid (All hydrogen atoms were omitted for clarity.)

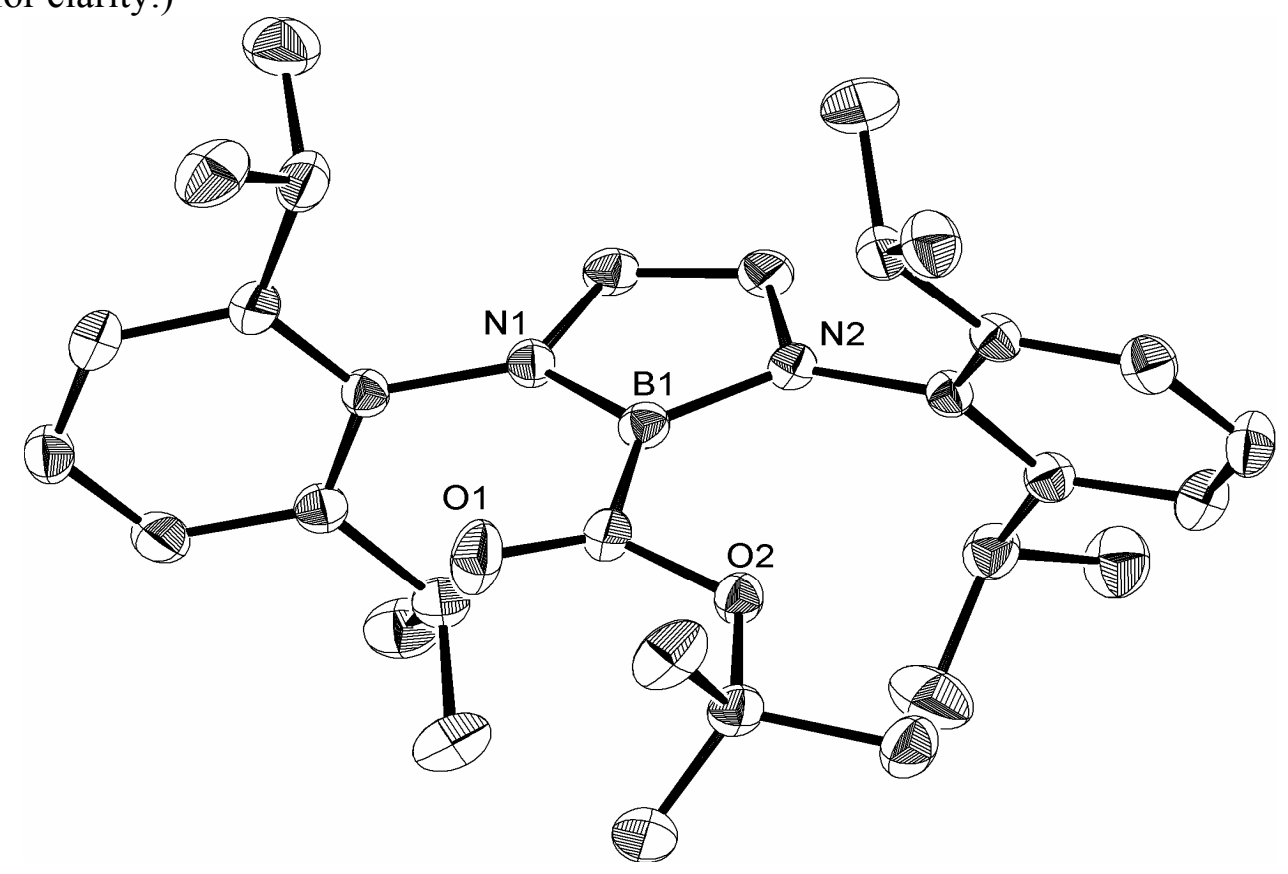


Figure S11. ORTEP drawing of $\mathbf{6 2}$ with $50 \%$ thermal ellipsoid (All hydrogen atoms were omitted for clarity.)

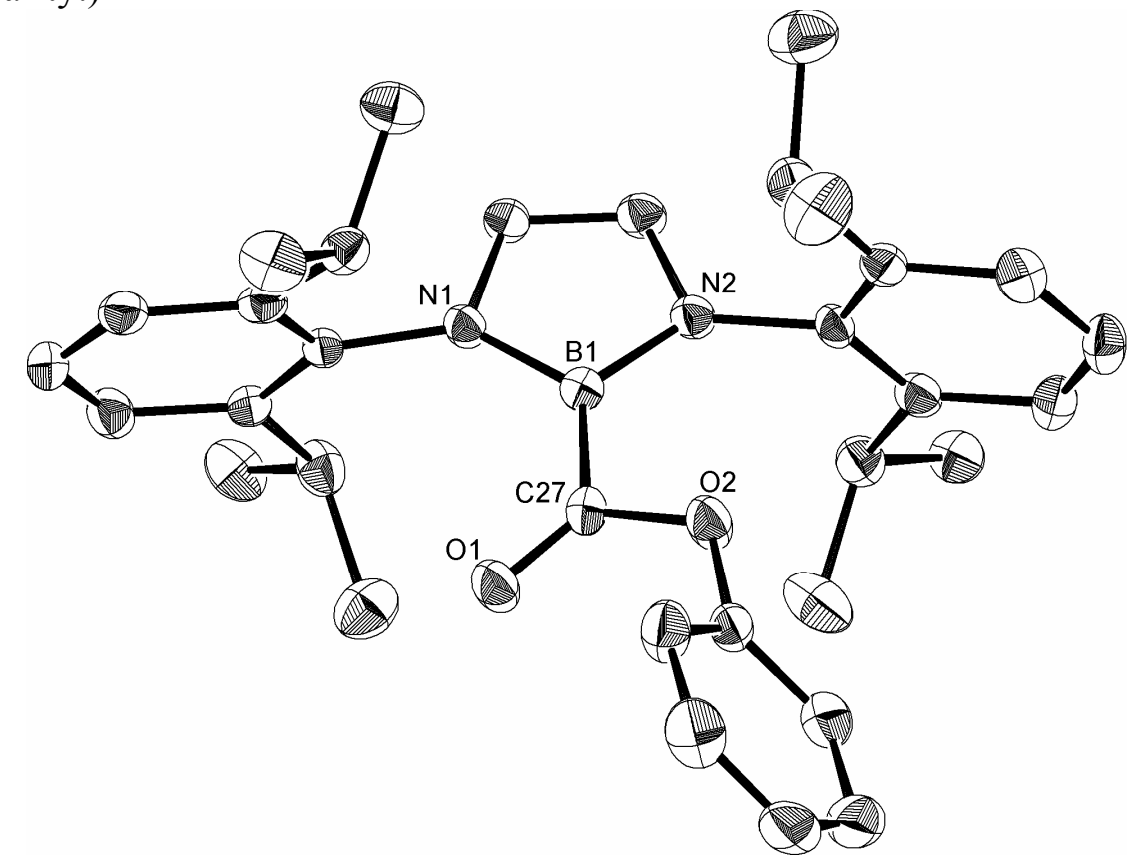

Figure S12. ORTEP drawing of 64a with 50\% thermal ellipsoid (All hydrogen atoms except the hydrogen atom on the oxygen atom and minor parts of disordered isopropyl groups were omitted for clarity.)

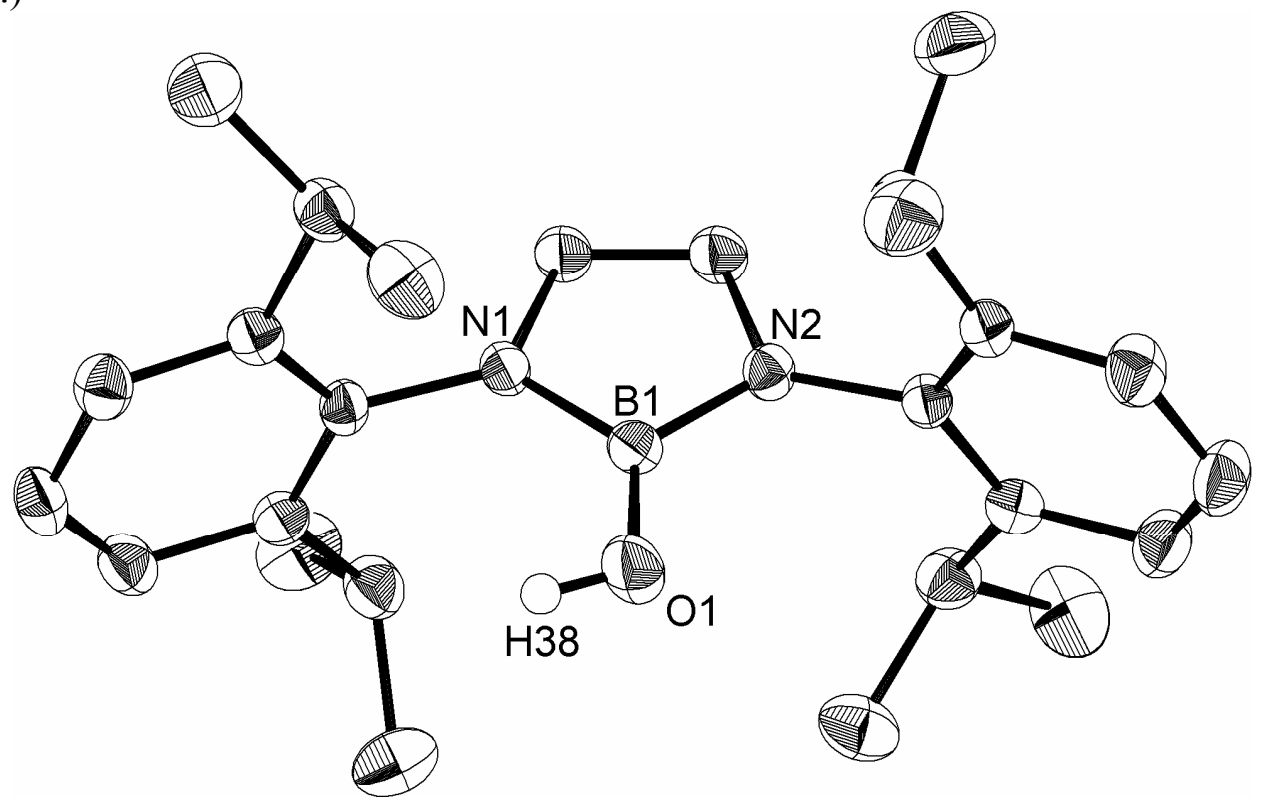


Figure S13. ORTEP drawing of $\mathbf{6 5}$ with 50\% thermal ellipsoid (All hydrogen atoms were omitted for clarity.)

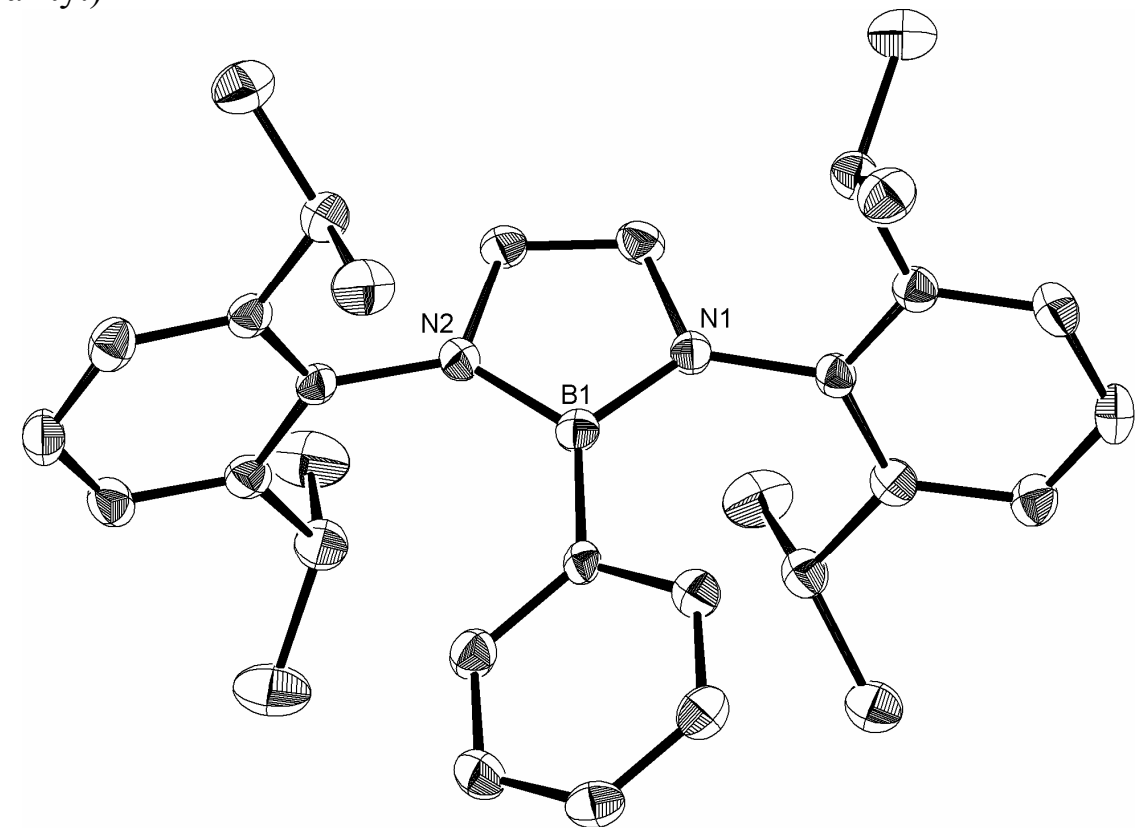


Computational Details. Gaussian 03 program $^{10}$ equipped onto SGI Altix4700 system was used for all optimization $(B 3 L Y P / 6-31+G(d))$, frequency analysis $(B 3 L Y P / 6-31+G(d))$, population analysis (B3LYP/6-31+G(d)), GIAO calculation (B3LYP/6-311++G(d,p)), and generating wavefunctions for AIM analyses (B3LYP/6-311++G(d,p)). Visualization of the results was performed by use of GaussView 3.0 software. AIM-2000 ver. 2.0 software was used for AIM analyses and generating molecular graphs. ${ }^{11,12}$

\section{Optimized Cartesian coordinates for opt-46a}

B $0 ., 0 ., 0.5293459601$

N $0.000001522,1.126398325,-0.4543131768$

C $0.0000006438,0.6795382315,-1.7856235687$

H $0.000001307,1.3546925344,-2.6347216482$

C $-0.0000006438,-0.6795382315,-1.7856235687$

H - $0.000001307,-1.3546925344,-2.6347216482$

N $-0.000001522,-1.126398325,-0.4543131768$

C $0.0000028023,2.520904686,-0.1692158881$

C $1.2280848931,3.2113168933,-0.0268895024$

C $1.2044017461,4.5825101943,0.2639187213$

H 2.142204287,5.1205240188,0.3881154398

C 0.0000051255,5.2697777391,0.4081676236

H 0.0000060015,6.334239813,0.637292387

C - $1.2043926387,4.5825122789,0.2639182991$

H - 2.1421943493,5.1205277117,0.3881144279

C - $1.2280780523,3.2113190086,-0.0268897829$

C $2.5607539621,2.4771720419,-0.1315889722$

H 2.3481707486, 1.4852135881,-0.5392420961

C $3.5546708276,3.1711596022,-1.0822602025$

H 3.1183242962,3.3168445479,-2.0783611844

H 4.4596629974,2.5589601852,-1.1942828321

H 3.8695969175,4.1544133396,-0.7074242596

C $3.1757816719,2.2663217258,1.266367127$

H 3.3865698124,3.2269190516,1.757606677

H 4.1197335672,1.707957998,1.1921323088

H 2.4852594433, 1.6929680682,1.8947397387

C $-2.5607484354,2.4771768467,-0.1315903585$

H - $2.3481670487,1.4852173537,-0.5392419328$

C $-3.5546622228,3.1711656859,-1.0822638818$

H -3.8695855789,4.1544210271,-0.707429788

H $-4.459656209,2.5589689029,-1.194286361$

H -3.118314302,3.3168476256,-2.0783646793

C - $3.1757791243,2.2663295707,1.2663648488$

H - $2.4852608218,1.6929725849,1.8947386581$

H -4.1197333645,1.7079700692,1.1921286079

H -3.3865638,3.2269280217,1.7576037709 
C $-0.0000028023,-2.520904686,-0.1692158881$

C $-1.2280848931,-3.2113168933,-0.0268895024$

C - $1.2044017461,-4.5825101943,0.2639187213$

H $-2.142204287,-5.1205240188,0.3881154398$

C $-0.0000051255,-5.2697777391,0.4081676236$

H $-0.0000060015,-6.334239813,0.637292387$

C $1.2043926387,-4.5825122789,0.2639182991$

H 2.1421943493,-5.1205277117,0.3881144279

C $1.2280780523,-3.2113190086,-0.0268897829$

C $-2.5607539621,-2.4771720419,-0.1315889722$

H $-2.3481707486,-1.4852135881,-0.5392420961$

C -3.5546708276,-3.1711596022,-1.0822602025

H -3.1183242962,-3.3168445479,-2.0783611844

H -4.4596629974,-2.5589601852,-1.1942828321

H -3.8695969175,-4.1544133396,-0.7074242596

C -3.1757816719,-2.2663217258,1.266367127

H -4.1197335672,-1.707957998,1.1921323088

H - 2.4852594433,-1.6929680682,1.8947397387

H -3.3865698124,-3.2269190516,1.757606677

C 2.5607484354,-2.4771768467,-0.1315903585

H 2.3481670487,-1.4852173537,-0.5392419328

C $3.5546622228,-3.1711656859,-1.0822638818$

H $3.8695855789,-4.1544210271,-0.707429788$

H 4.459656209,-2.5589689029,-1.194286361

H 3.118314302,-3.3168476256,-2.0783646793

C $3.1757791243,-2.2663295707,1.2663648488$

H 2.4852608218,-1.6929725849,1.8947386581

H 4.1197333645,-1.7079700692,1.1921286079

H 3.3865638,-3.2269280217, 1.7576037709

\section{Optimized Cartesian coordinates for opt-35a}

B 0.,0.,-0.3409221744

N $-0.0016774748,1.1317983383,-1.2736275785$

C $-0.0010069007,0.6793794673,-2.5993924144$

H $-0.0020154291,1.3596021483,-3.4412157184$

C 0.0010069007,-0.6793794673,-2.5993924144

H $0.0020154291,-1.3596021483,-3.4412157184$

N 0.0016774748,-1.1317983383,-1.2736275785

Li 0.,0.,1.8177927998

C $-0.003747558,2.5298903452,-0.96952253$

C 1.2261311234,3.214060849,-0.8211125128

C 1.1979060782,4.5796714494,-0.5051736291

H 2.1337401371,5.1208616734,-0.3861503

C $-0.0077887838,5.2597478696,-0.3449953783$ 
H $-0.0093579426,6.3197628481,-0.1015043688$

C - $1.2114648216,4.5761039039,-0.5051698704$

H $-2.1488971454,5.1145203048,-0.3861435578$

C - $1.2356465461,3.2104156497,-0.8211087256$

C 2.5679299741,2.5107618337,-1.0052864704

H 2.3597077006, 1.4607622347,-1.2269717253

C $3.3548333963,3.0903228673,-2.1982800721$

H 2.7697857574,3.0339641896,-3.1232969792

H 4.285697241,2.5295122176,-2.3512663077

H 3.6219107692,4.1420584129,-2.0347396995

C $3.4179136549,2.548555844,0.2798768745$

H 3.682778156,3.5749345151,0.5632815623

H 4.3522017978, $1.9905404387,0.1381369428$

H 2.8782701448,2.0968282549,1.1208895406

C $-2.5753577691,2.5031463634,-1.0052767547$

H $-2.3640281376,1.4537714557,-1.2269793191$

C -3.3639917743,3.0803889796,-2.1982513249

H -3.6341845426,4.1313257387,-2.0346934525

H -4.2931909186,2.5168230772,-2.3512325453

H - $2.7787922727,3.025777727,-3.1232770242$

C - $3.4254318124,2.5384045106,0.2798991017$

H - $2.8844411784,2.0882634179,1.1208969497$

H $-4.3580662335,1.9776281916,0.1381643634$

H -3.6933282389,3.563990838,0.563322591

C $0.003747558,-2.5298903452,-0.96952253$

C - $1.2261311234,-3.214060849,-0.8211125128$

C - $1.1979060782,-4.5796714494,-0.5051736291$

H $-2.1337401371,-5.1208616734,-0.3861503$

C $0.0077887838,-5.2597478696,-0.3449953783$

H 0.0093579426,-6.3197628481,-0.1015043688

C 1.2114648216,-4.5761039039,-0.5051698704

H 2.1488971454,-5.1145203048,-0.3861435578

C $1.2356465461,-3.2104156497,-0.8211087256$

C - $2.5679299741,-2.5107618337,-1.0052864704$

H -2.3597077006,-1.4607622347,-1.2269717253

C -3.3548333963,-3.0903228673,-2.1982800721

H - 2.7697857574,-3.0339641896,-3.1232969792

H $-4.285697241,-2.5295122176,-2.3512663077$

H -3.6219107692,-4.1420584129,-2.0347396995

C -3.4179136549,-2.548555844,0.2798768745

H $-4.3522017978,-1.9905404387,0.1381369428$

H - 2.8782701448,-2.0968282549,1.1208895406

H -3.682778156,-3.5749345151,0.5632815623

C 2.5753577691,-2.5031463634,-1.0052767547 
H 2.3640281376,-1.4537714557,-1.2269793191 C $3.3639917743,-3.0803889796,-2.1982513249$ H 3.6341845426,-4.1313257387,-2.0346934525 H 4.2931909186,-2.5168230772,-2.3512325453 H 2.7787922727,-3.025777727,-3.1232770242 C $3.4254318124,-2.5384045106,0.2798991017$ H 2.8844411784,-2.0882634179,1.1208969497 H 4.3580662335,-1.9776281916,0.1381643634 H 3.6933282389,-3.563990838,0.563322591

Optimized Cartesian coordinates for opt-35a-(THF) B -0.0121077281,-0.6445472707,0.0137516221 N - $1.1583413031,-1.5803600463,-0.0485751165$ C $-0.7395737281,-2.916989,0.0080310294$ H $-1.4356166569,-3.7457198994,-0.024985035$ C $0.613904444,-2.945179739,0.1055722932$ H 1.2725500404,-3.8021241406,0.1703256596 N 1.0915640364,-1.6272475075,0.1122000809 Li $0.0381951985,1.6215613273,-0.0289205426$ C - $2.545762654,-1.2664876492,-0.1616897298$ C - $3.1450045424,-1.1875200615,-1.4423764446$ C $-4.5053522176,-0.858818056,-1.5289557892$ H -4.9793184446,-0.7936757152,-2.5059451879 C $-5.2657773273,-0.6197448475,-0.3851089728$ H -6.3210577811,-0.3699366312,-0.4718388028 C $-4.6690763406,-0.7180828529,0.8711918816$ H -5.2709320215,-0.5460961169,1.7610198458 C -3.3125930504,-1.0468884503,1.0083559189 C $-2.3524943896,-1.4663275443,-2.7165531769$ H $-1.3203421024,-1.6672900892,-2.4185373465$ C $-2.8807336461,-2.7172547493,-3.4477735197$ H -2.8661533351,-3.5949348555,-2.7916060645 H -2.2585967668,-2.9394356137,-4.3242484039 H -3.9119159996,-2.5770162331,-3.7969466384 C $-2.3261405394,-0.250430187,-3.6627225554$ H -3.3317099693,0.0187006262,-4.0109900487 H - $1.7160402879,-0.4694089179,-4.548453584$ H $-1.8930391508,0.6235658028,-3.163043243$ C -2.7042355687,-1.1778284641,2.4016982068 H - $1.6503413826,-1.4361424273,2.2711734494$ C -3.3687985304,-2.3124463719,3.2072162405 H $-4.4296735549,-2.1070222627,3.4000516766$ H -2.8711652686,-2.433949856,4.1778953187 H -3.3047795602,-3.2670022807,2.672512637 
C - $2.7548552336,0.1503769432,3.1810444995$

H - $2.2252641913,0.9395525753,2.6350960247$ H $-2.275622705,0.0374683713,4.1620720167$

H - $3.7871829527,0.4830197649,3.3517412653$

C $2.4916301718,-1.3711599341,0.214586466$

C $3.0948510718,-1.2707149079,1.4918962817$

C 4.4685061433,-0.9996240217,1.5671857441

H 4.9457089331,-0.9188531224,2.5414287585

C 5.2378295142,-0.837701059,0.4157907538

H $6.3032199311,-0.6318406129,0.4939433285$

C 4.636308516,-0.9566796562,-0.8364197923

H 5.244456341,-0.8451450061,-1.7315844972

C 3.2664673205,-1.2299477913,-0.9622508206

C $2.2918224635,-1.4659884427,2.7749964479$

H 1.2515256989,-1.6320516106,2.4838893129

C 2.7646855598,-2.7107235258,3.5531831352

H 2.7106517788,-3.6109489691,2.9304752903

H 2.1340428664,-2.8719796122,4.4368759987

H 3.8013643095,-2.6033151851,3.8976920459

C 2.3201995705,-0.2153976587,3.6747485739

H 1.701733946,-0.3736462816,4.567581685

H 1.9258547294,0.6575318756,3.1421966555

H 3.3370044558,0.0217907414,4.0134829579

C 2.6517423106,-1.3861186057,-2.3501884258

H $1.5875387881,-1.5923480238,-2.2109188985$

C 3.2646659606,-2.5785984868,-3.1118823947

H 4.3334468266,-2.4278242848,-3.3114194511

H 2.7613284976,-2.7143546004,-4.0777196024

H 3.158822222,-3.5085785702,-2.5416917437

C 2.7605639246,-0.0917343938,-3.1789218786

H 2.2669465447,0.7401355813,-2.663500789

H 2.2759775247,-0.2201164781,-4.155405928

H $3.8064847582,0.1881418862,-3.3611527287$

O $1.5639092524,2.879452925,-0.0669661735$

C 2.8730847092,2.5460671329,0.482110727

H $3.117058846,1.5267074228,0.1722667064$

H 2.7994148788,2.5770143269, 1.5731090305

C 3.8440087195,3.5834920766,-0.0919784884

H 3.9235523482,4.4532468907,0.5720114724

H 4.8473485348,3.1694349568,-0.2295686471

C $3.1668749445,3.98130246,-1.4141548373$

H 3.4813718764,4.9628212606,-1.7837141561

H 3.3748081835,3.2374690234,-2.191928787

C 1.6880150316,3.9494799731,-1.0307482984 
H 1.3741326835,4.8918739409,-0.5593259812

H 1.0140901647,3.7329628889,-1.8646744926

O $-1.4301734923,2.9464334456,-0.039575378$

C - $1.5057803728,4.0566985143,0.8828133551$

H $-1.151179408,4.9657616075,0.3761200536$

H - $0.8410742363,3.8424286977,1.7246785466$

C $-2.9813407788,4.1682896059,1.2639811573$

H $-3.2517601247,5.1760004158,1.5960270711$

H $-3.2210207555,3.4642722122,2.0691954185$

C $-3.6768965922,3.7511362428,-0.0425812326$

$\mathrm{H}-4.6973617396,3.3872374787,0.1100382116$

H - 3.718784726,4.5978896083,-0.7389542295

C $-2.7533578846,2.6509527859,-0.5766583066$

H -3.041863439,1.655724956,-0.2289516165

H -2.679473091,2.6376623333,-1.6680020752

\section{Optimized Cartesian coordinates for opt-35a-(THF)}

B $\quad-0.18828 \quad-0.72964 \quad 0.45533$

$\begin{array}{llll}\mathrm{N} & 0.78331 & -1.73758 & 0.95794\end{array}$

$\begin{array}{llll}\text { C } & 0.14437 & -2.79246 & 1.6274\end{array}$

$\begin{array}{llll}\text { C } & -1.19206 & -2.57196 & 1.61122\end{array}$

$\begin{array}{llll}\mathrm{N} & -1.44705 & -1.36859 & 0.93479\end{array}$

$\begin{array}{llll}\text { C } & 2.19439 & -1.80431 & 0.75321\end{array}$

$\begin{array}{llll}\text { C } & 2.70247 & -2.4826 & -0.38239\end{array}$

C $4.09187-2.55768 \quad-0.55729$

$\begin{array}{llll}\text { C } & 4.96851 & -1.98986 & 0.36547\end{array}$

C $4.45854-1.33567 \quad 1.48604$

$\begin{array}{llll}\text { C } & 3.0769 & -1.23159 & 1.70185\end{array}$

$\begin{array}{llll}\text { C } & 1.78 & -3.13882 & -1.40582\end{array}$

$\begin{array}{llll}\text { C } & 2.0056 & -4.662 & -1.4841\end{array}$

$\begin{array}{llll}\text { C } & 1.91469 & -2.49067 & -2.79748\end{array}$

$\begin{array}{llll}\text { C } & 2.55222 & -0.55 & 2.96159\end{array}$

C $3.21573 \quad 0.81516 \quad 3.22286$

C $2.70526-1.46692 \quad 4.19332$

C $\quad-2.80001 \quad-0.99305 \quad 0.67008$

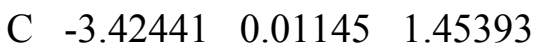

$\begin{array}{llll}\text { C } & -4.75672 & 0.34828 & 1.17759\end{array}$

$\begin{array}{llll}\text { C } & -5.47374 & -0.2955 & 0.16884\end{array}$

C $-4.85865-1.29508-0.58001$

C $\quad-3.52358-1.66002-0.34995$

$\begin{array}{llll}\text { C } & -2.68553 & 0.66191 & 2.62145\end{array}$

$\begin{array}{llll}\text { C } & -2.80315 & -0.20542 & 3.89418\end{array}$

$\begin{array}{llll}\text { C } & -3.14438 & 2.09777 & 2.92912\end{array}$

$\begin{array}{llll}\text { C } & -2.90474 & -2.78724 & -1.17478\end{array}$ 

C $\quad-3.02793-2.5565-2.69318$
C $-3.51358-4.15371-0.79516$
$\begin{array}{llll}\text { Li } & 0.29692 & 1.29474 & -0.66346\end{array}$
$\begin{array}{lllll}\text { O } & 0.66388 & 3.02198 & 0.42953\end{array}$
C $\quad 1.23854 \quad 4.22825 \quad-0.11821$
C $\quad 1.2026 \quad 5.26834 \quad 1.00862$
$\begin{array}{llll}\text { C } & 1.26523 & 4.38681 & 2.26721\end{array}$
$\begin{array}{llll}\text { C } & 0.42213 & 3.18347 & 1.84588\end{array}$
$\begin{array}{lllll}\text { O } & -1.09851 & 2.16141 & -1.93048\end{array}$
$\begin{array}{llll}\text { C } & -1.60294 & 1.3592 & -3.02784\end{array}$
$\begin{array}{lllll}\text { C } & -3.12534 & 1.54131 & -3.03138\end{array}$
$\begin{array}{llll}\text { C } & -3.29566 & 2.92131 & -2.37544\end{array}$
C $\quad-2.184992 .90077 \quad-1.32652$
$\begin{array}{lllll}\text { O } & 1.94917 & 1.53988 & -1.8965\end{array}$
C $\quad 3.28755 \quad 1.2225 \quad-1.43866$
$\begin{array}{llll}\text { C } & 4.15874 & 1.19261 & -2.69596\end{array}$
$\begin{array}{llll}\text { C } & 3.45447 & 2.21416 & -3.6041\end{array}$
C $\quad 1.97946 \quad 1.96836-3.27386$
H $\quad 0.69044 \quad-3.61717 \quad 2.06796$
$\mathrm{H} \quad-1.98225 \quad-3.17823 \quad 2.03539$
H $4.49484-3.07553-1.42506$
H $\quad 6.04369 \quad-2.06388 \quad 0.21717$
H $\quad 5.14837 \quad-0.90592 \quad 2.20845$
H $\quad 0.7535-2.97184-1.07063$
H 3.01384 -4.90668 -1.84258
H $\quad 1.28679 \quad-5.1192 \quad-2.17616$
H $\quad 1.87582-5.13213 \quad-0.50266$
H $\quad 1.69233-1.41898 \quad-2.74708$
H $\quad 1.21158 \quad-2.95161 \quad-3.50344$
H $\quad 2.92574-2.61514 \quad-3.20756$
H $\quad 1.48318 \quad-0.37647 \quad 2.80671$
H $\quad 4.28019 \quad 0.71715 \quad 3.47028$
H $\quad 2.73132 \quad 1.31497 \quad 4.07175$
H $\quad 3.13443 \quad 1.47014 \quad 2.34758$
H $\quad 2.18319 \quad-2.41817 \quad 4.04518$
H $\quad 2.28534 \quad-0.98675 \quad 5.08689$
H $\quad 3.76195 \quad-1.6883 \quad 4.39331$
H $\quad-5.25158 \quad 1.11481 \quad 1.76728$
H $\quad-6.50999 \quad-0.02537 \quad-0.02288$
$\mathrm{H} \quad-5.42664 \quad-1.80442-1.35533$
$\begin{array}{llll}\mathrm{H} & -1.62679 & 0.69737 & 2.34348\end{array}$
H $\quad-3.85234 \quad-0.30259 \quad 4.20343$
H $\quad-2.24629 \quad 0.25076 \quad 4.72363$
H $\quad-2.39944 \quad-1.20858 \quad 3.72982$ 


$$
\begin{array}{llll}
\text { H } & -3.12585 & 2.73471 & 2.03631 \\
\text { H } & -2.48272 & 2.54651 & 3.68057 \\
\text { H } & -4.16068 & 2.12978 & 3.34167 \\
\text { H } & -1.83869 & -2.81996 & -0.93561 \\
\text { H } & -2.51516 & -3.3586 & -3.23911 \\
\text { H } & -2.57366 & -1.60518 & -2.98943 \\
\text { H } & -4.07338 & -2.54985 & -3.02647 \\
\text { H } & -3.394 & -4.36069 & 0.27356 \\
\text { H } & -3.02228 & -4.96152 & -1.35269 \\
\text { H } & -4.58622 & -4.18926 & -1.02629 \\
\text { H } & 0.65958 & 4.51837 & -1.00149 \\
\text { H } & 2.26534 & 4.0067 & -0.4348 \\
\text { H } & 2.02626 & 5.98633 & 0.93813 \\
\text { H } & 0.26122 & 5.83126 & 0.98547 \\
\text { H } & 0.87212 & 4.88121 & 3.16151 \\
\text { H } & 2.29778 & 4.07946 & 2.47296 \\
\text { H } & 0.69071 & 2.24471 & 2.33464 \\
\text { H } & -0.64786 & 3.36966 & 2.00368 \\
\text { H } & -1.28825 & 0.32436 & -2.86121 \\
\text { H } & -1.14414 & 1.73028 & -3.95403 \\
\text { H } & -3.60447 & 0.77194 & -2.41713 \\
\text { H } & -3.54631 & 1.48679 & -4.04082 \\
\text { H } & -3.12481 & 3.7248 & -3.10344 \\
\text { H } & -4.28537 & 3.06439 & -1.93023 \\
\text { H } & -1.80462 & 3.89135 & -1.05969 \\
\text { H } & -2.50514 & 2.37983 & -0.41576 \\
\text { H } & 3.2471 & 0.27362 & -0.90209 \\
\text { H } & 3.60988 & 2.01041 & -0.74328 \\
\text { H } & 4.13675 & 0.19514 & -3.15018 \\
\text { H } & 5.2025 & 1.44633 & -2.48489 \\
\text { H } & 3.74558 & 3.23645 & -3.33113 \\
\text { H } & 3.67195 & 2.07334 & -4.66802 \\
\text { H } & 1.3476 & 2.85683 & -3.36836 \\
\text { H } & 1.55745 & 1.16961 & -3.89935
\end{array}
$$

\section{Optimized Cartesian coordinates for opt-38a}

B $0.0000041717,-0.0000024742,-0.5126842412$ H $0.0000028331,-0.0000082467,-1.6998528752$ $\mathrm{N}-1.1414056738,-0.0000734986,0.3587035012$ C $-0.6793547431,-0.0000368874,1.6837428254$ H - $1.3632161568,-0.0000775087,2.5212822632$ C $0.6793680542,0.0000533547,1.6837412888$ H 1.3632313554,0.0001026874,2.5212791857 N 1.1414159872,0.0000773253,0.3587009193 
C $-2.5403228958,-0.0001686206,0.0356817714$

C $-3.2138356844,1.2327157498,-0.1197096515$

C $-4.5762270182,1.2051227217,-0.4478410878$

H -5.1138824608,2.1409991883,-0.5779671608

C $-5.2550033971,-0.0003532284,-0.6125685729$

H $-6.3118492162,-0.0004250654,-0.8685164883$

C $-4.5760694069,-1.2057367372,-0.4478147786$

H -5.1136021351,-2.1416863987,-0.5779213147

C $-3.2136744759,-1.2331443675,-0.119682324$

C - $2.5043130739,2.5737555466,0.0456157563$

H - $1.4739904363,2.3697089383,0.3508299591$

C $-2.4444041969,3.3471913643,-1.2873208328$

H $-3.4483858623,3.6035525228,-1.6477830221$

H - $1.9497142914,2.7565076148,-2.0665913046$

H - 1.8852909025,4.2830273018,-1.1622119608

C -3.1463329105,3.4335790873,1.1526835883

H -4.1761914818,3.7162236792,0.9022491788

H - 2.5740602765,4.3587832668,1.2949441445

H -3.1697193977,2.8986784108,2.1091869913

C $-2.5039764843,-2.5740879904,0.0456711521$

H - $1.4736781816,-2.3699003919,0.3508730918$

C - $2.4439756947,-3.3475505384,-1.2872453091$

H -3.4479258723,-3.6040499988,-1.6476967245

H - $1.8847420208,-4.2833116325,-1.162114456$

H - $1.9493647758,-2.7568238981,-2.0665335139$

C $-3.1458783468,-3.4339661568,1.152765568$

H -4.1757006495,-3.7167527316,0.9023422361

H -3.1693318681,-2.8990422909,2.1092542941

H - $2.5734834562,-4.359091091,1.2950494121$

C 2.5403324696,0.0001690942,0.0356759905

C 3.2138452846,-1.2327168292,-0.1197029672

C $4.5762358312,-1.2051271021,-0.4478380267$

H 5.1138911836,-2.1410048839,-0.5779549824

C 5.2550114666,0.000347187,-0.6125806466

H $6.3118566919,0.0004164825,-0.868531007$

C $4.5760775011,1.2057323573,-0.4478388217$

H 5.1136097209,2.1416807041,-0.5779569412

C 3.2136833051,1.2331432825,-0.1197036646

C $2.504323526,-2.5737550173,0.045639192$

H 1.4740015863,-2.3697054167,0.3508537106

C 2.4444114122,-3.3472059422,-1.2872884041

H 1.9497186057,-2.7565314379,-2.0665640645

H 1.8852992584,-4.2830409189,-1.1621672215

H 3.4483921564,-3.6035703779,-1.6477508189 
C $3.1463466321,-3.4335658486,1.1527151046$ H 4.1762043628,-3.716213481,0.9022806497 H 2.5740743154,-4.3587682895,1.2949881852 H 3.16973625,-2.8986540718,2.1092122081 C $2.5039852185,2.5740884862,0.0456364171$ H 1.4736877566,2.3699038596,0.3508432263 C $2.4439809453,3.3475357433,-1.2872888506$ H $1.8847468579,4.283297868,-1.1621675912$ H 1.9493689102,2.7567997993,-2.0665692683 H 3.4479302406,3.6040317796,-1.6477451788 C $3.1458892651,3.4339795866,1.1527194234$ H 4.1757111246,3.7167631971,0.9022909556 H 3.1693444869,2.8990669649,2.109214412 H 2.5734946767,4.3591062232,1.2949934712

Optimized Cartesian coordinates for opt-46b B 0.,0.,-0.678152544

N $-0.1380304438,1.1274553956,-1.6161552709$ C $-0.2374347939,0.7305610468,-3.0394973874$ H 0.3807313975,1.3669153366,-3.69271467

H - $1.2777968591,0.8142790428,-3.4066734383$ C $-0.4237916756,2.482846582,-1.3078628727$ C $-1.7492113151,2.9002314441,-1.0209703581$ C - $1.9948540757,4.2499250967,-0.7310373636$ H -3.008117625,4.5711179643,-0.4952705501 C $-0.9651749105,5.1892634973,-0.7283910097$ H - $1.1738121602,6.2330523654,-0.4988513754$ C 0.3368616696,4.7783128893,-1.0132756198 H 1.1410167018,5.5115208034,-0.9952593001 C $0.6258752742,3.4392753251,-1.3075766261$ C - $2.9004166935,1.9012934346,-0.9793008002$ H - $2.504801875,0.9442837856,-1.3301847493$ C -4.0688177212,2.3048821114,-1.9001509154 H $-4.5537656878,3.2325359787,-1.5668880299$ H $-4.8356741905,1.5182375185,-1.9084659939$ H -3.7288854597,2.4593195785,-2.9319001076 C $-3.3819614802,1.6740164058,0.4671087037$ H - 2.5538226979,1.2990727834,1.0781319108 H - $4.1909105302,0.9302885135,0.4914116498$ H -3.7621940491,2.6036063492,0.9140525296 C 2.0675088051,3.0030376359,-1.5460160475 H 2.0247342176,2.0078214251,-1.998094982 C 2.8088993314,2.8463642041,-0.2026975799 H 2.863189145,3.8055368977,0.3314257763 
H 3.8356590832,2.4880896819,-0.3647052451 H 2.2862426021,2.1225708059,0.4326520438 C 2.8395737774,3.9282929137,-2.504378199 H 2.3080723642,4.0530256609,-3.4563105131 H 3.8303810757,3.5061615357,-2.7205382543 H 2.9991472432,4.9277340126,-2.0778653094 N 0.1380304438,-1.1274553956,-1.6161552709 C $0.2374347939,-0.7305610468,-3.0394973874$ H - $0.3807313975,-1.3669153366,-3.69271467$ H $1.2777968591,-0.8142790428,-3.4066734383$ C $0.4237916756,-2.482846582,-1.3078628727$ C 1.7492113151,-2.9002314441,-1.0209703581 C 1.9948540757,-4.2499250967,-0.7310373636 H 3.008117625,-4.5711179643,-0.4952705501 C $0.9651749105,-5.1892634973,-0.7283910097$ H 1.1738121602,-6.2330523654,-0.4988513754 C $-0.3368616696,-4.7783128893,-1.0132756198$ H - $1.1410167018,-5.5115208034,-0.9952593001$ C $-0.6258752742,-3.4392753251,-1.3075766261$ C $2.9004166935,-1.9012934346,-0.9793008002$ H 2.504801875,-0.9442837856,-1.3301847493 C $4.0688177212,-2.3048821114,-1.9001509154$ H 4.5537656878,-3.2325359787,-1.5668880299 H 4.8356741905,-1.5182375185,-1.9084659939 H 3.7288854597,-2.4593195785,-2.9319001076 C $3.3819614802,-1.6740164058,0.4671087037$ H 2.5538226979,-1.2990727834,1.0781319108 H 4.1909105302,-0.9302885135,0.4914116498 H 3.7621940491,-2.6036063492,0.9140525296 C -2.0675088051,-3.0030376359,-1.5460160475 H - 2.0247342176,-2.0078214251,-1.998094982 C $-2.8088993314,-2.8463642041,-0.2026975799$ H - $2.863189145,-3.8055368977,0.3314257763$ H $-3.8356590832,-2.4880896819,-0.3647052451$ H - 2.2862426021,-2.1225708059,0.4326520438 C -2.8395737774,-3.9282929137,-2.504378199 H $-2.3080723642,-4.0530256609,-3.4563105131$ H -3.8303810757,-3.5061615357,-2.7205382543 H -2.9991472432,-4.9277340126,-2.0778653094

Optimized Cartesian coordinates for opt-46c B 0.,0.,0.9576409548

N 1.137371695,0.0082582593,-0.0248444095 C 0.7103478409,0.0051565746,-1.3520642249 
C $1.4178389139,0.0102931051,-2.5556558935$ H 2.5052036081, $0.018187337,-2.5545262697$ C 0.6997256145,0.0050799381,-3.7649447971 H $1.2420852058,0.0090177825,-4.708759934$ C 2.5285849981,0.0183591546,0.2902675067 C 3.2042533993,1.2519181587,0.448086585

C $4.5668497868,1.2376303235,0.7770698186$ H 5.0946010717,2.1790218039,0.9148257761 C 5.2578503007,0.0381748327,0.9408200553 H $6.3154257197,0.0458530964,1.1992798804$ C $4.5843391777,-1.1711876902,0.7770681073$ H 5.1257044121,-2.1048167963,0.9148229869 C $3.2220941071,-1.2052591071,0.4480849063$ C $2.4659088375,2.5805162929,0.322000225$ H $1.4933342673,2.367538662,-0.1295138584$ C 3.1905481233,3.587028393,-0.5914409153 H 4.1527061429,3.9096473303,-0.1715395515 H 2.5739899291,4.4860653471,-0.7234948599 H 3.3816824654,3.1590494335,-1.5829537494 C 2.1934810505,3.1820596687, 1.7154335561 H 1.603581649,2.4817650631,2.3172306878 H 1.6301925194,4.1215595669,1.6261043081 H 3.1324293284,3.3975115989,2.2446547829 C 2.5031190404,-2.5444379028,0.3219969167 H 1.5275558583,-2.3456048095,-0.1295200809 C $2.2394511591,-3.1498725431,1.7154299433$ H 3.1814276424,-3.3516698312,2.2446526182 H 1.6898618934,-4.0974512755,1.6260999297 H 1.6394460878,-2.4582157676,2.3172258118 C 3.242299386,-3.5403223151,-0.591441546 H 3.4271985411,-3.1096148436,-1.5829552496 H 2.6388623984,-4.448218608,-0.7234937545 H 4.2090409733,-3.8489335529,-0.1715393752 N $-1.137371695,-0.0082582593,-0.0248444095$ C $-0.7103478409,-0.0051565746,-1.3520642249$ C - $1.4178389139,-0.0102931051,-2.5556558935$ H $-2.5052036081,-0.018187337,-2.5545262697$ C $-0.6997256145,-0.0050799381,-3.7649447971$ H - $1.2420852058,-0.0090177825,-4.708759934$ C $-2.5285849981,-0.0183591546,0.2902675067$ C $-3.2042533993,-1.2519181587,0.448086585$ C $-4.5668497868,-1.2376303235,0.7770698186$ H -5.0946010717,-2.1790218039,0.9148257761 C - $5.2578503007,-0.0381748327,0.9408200553$ 
H -6.3154257197,-0.0458530964,1.1992798804

C $-4.5843391777,1.1711876902,0.7770681073$

H -5.1257044121,2.1048167963,0.9148229869

C $-3.2220941071,1.2052591071,0.4480849063$

C $-2.4659088375,-2.5805162929,0.322000225$

H $-1.4933342673,-2.367538662,-0.1295138584$

C $-3.1905481233,-3.587028393,-0.5914409153$

H $-4.1527061429,-3.9096473303,-0.1715395515$

H -2.5739899291,-4.4860653471,-0.7234948599

H -3.3816824654,-3.1590494335,-1.5829537494

C - $2.1934810505,-3.1820596687,1.7154335561$

H - $1.603581649,-2.4817650631,2.3172306878$

H - 1.6301925194,-4.1215595669,1.6261043081

H -3.1324293284,-3.3975115989,2.2446547829

C - $2.5031190404,2.5444379028,0.3219969167$

H - $1.5275558583,2.3456048095,-0.1295200809$

C - $2.2394511591,3.1498725431,1.7154299433$

H -3.1814276424,3.3516698312,2.2446526182

H - $1.6898618934,4.0974512755,1.6260999297$

H - $1.6394460878,2.4582157676,2.3172258118$

C -3.242299386,3.5403223151,-0.591441546

H -3.4271985411,3.1096148436,-1.5829552496

H - 2.6388623984,4.448218608,-0.7234937545

H -4.2090409733,3.8489335529,-0.1715393752

Optimized Cartesian coordinates for $\mathbf{P h}^{-}$

C 0.8837857098,-0.8394127292,0.0006191083

C $2.2902870298,-0.8628241541,0.0011750558$

C $3.0101731837,0.339773848,0.0006771077$

C $2.2904018282,1.5424455426,-0.0003630697$

C $0.8839035262,1.5191719558,-0.000878267$

C $0.0890535023,0.3399153839,-0.0004347899$

H 0.3835808379,-1.8170019182,0.001057222

H 2.8295107778,-1.8164338675,0.0019916157

H 4.1012820366,0.339725187,0.0010901465

H 2.8297255183,2.4959992061,-0.0007720464

H 0.3837875194,2.4968055657,-0.001709083 
Figure S14. Molecular graph of opt-35a $\cdot(\mathrm{THF})_{2}$ (purple: boron, blue: nitrogen, black: carbon, red: oxygen, dark gray: lithium, gray: hydrogen, small red: bond critical point)

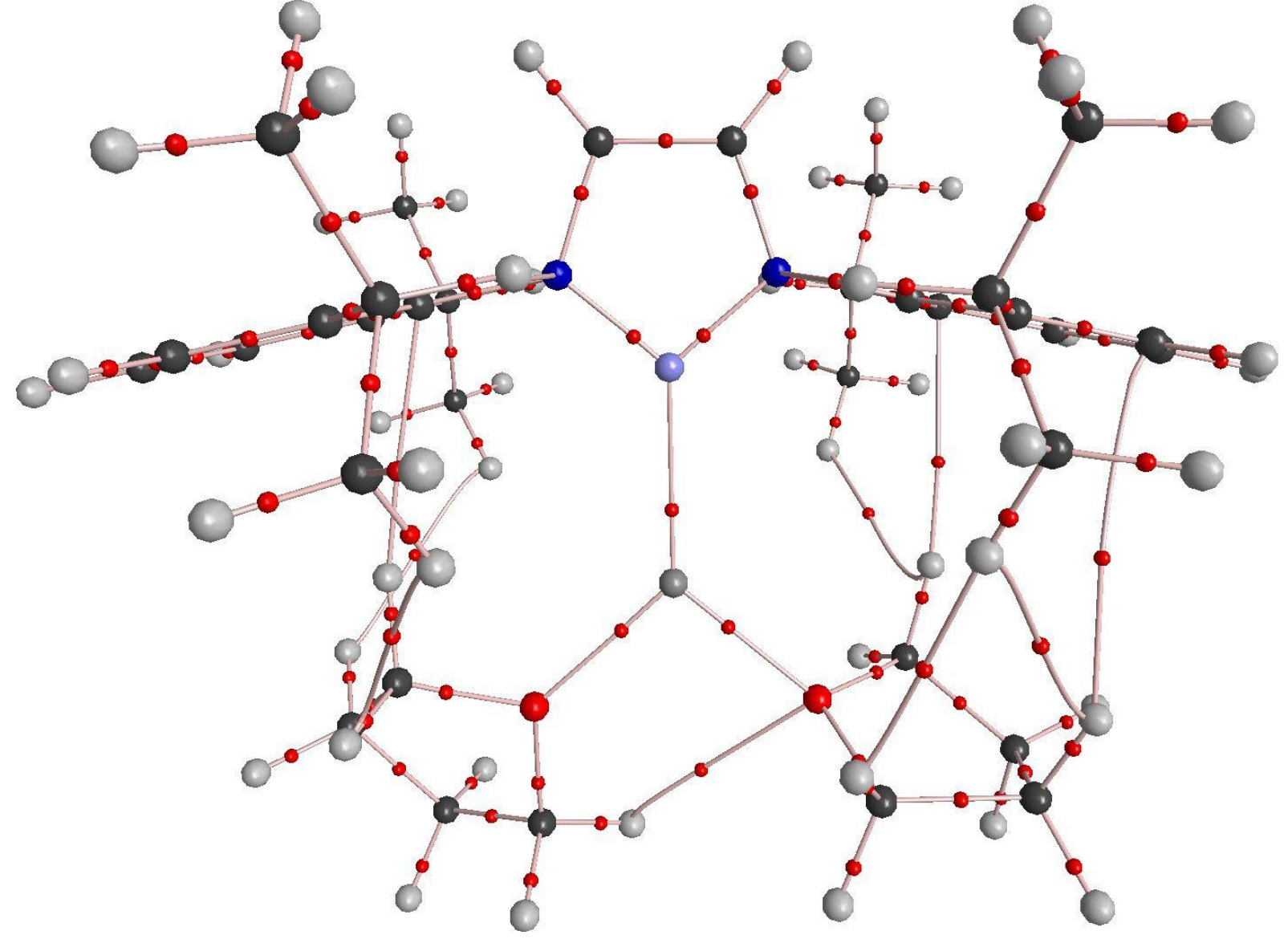


Figure S15. Molecular graph of opt-PhLi·(THF) $)_{3}$ (blue: nitrogen, black: carbon, red: oxygen, dark gray: lithium, gray: hydrogen, small red: bond critical point)

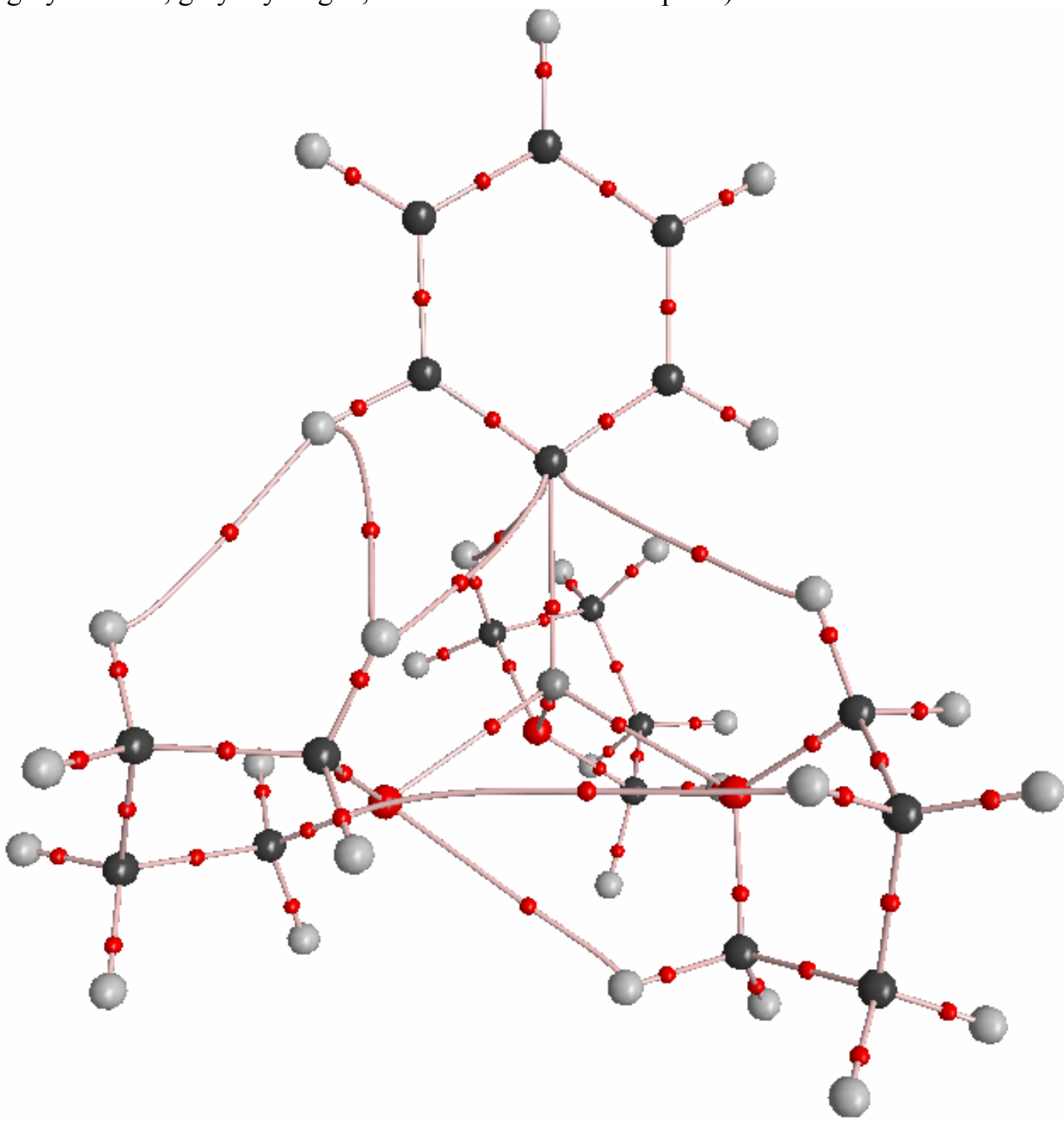




\section{References}

(1) Bailey, P. L.; Coxall, R. A.; Dick, C. M.; Fabre, S.; Henderson, L. C.; Herber, C.; Liddle, S. T.; Lorono-Gonzalez, D.; Parkin, A.; Parsons, S. Chem. Eur. J. 2003, 9, 4820-4828.

(2) Weber, L.; Dobbert, E.; Stammler, H. G.; Neumann, B.; Boese, R.; Blaser, D. Chem. Ber. 1997, 130, 705-710.

(3) Weber, L.; Domke, I.; Greschner, W.; Miqueu, K.; Chrostowska, A.; Baylere, P. Organometallics 2005, 24, 5455-5463.

(4) Abrams, M. B.; Scott, B. L.; Baker, R. T. Organometallics 2000, 19, 4944-4956.

(5) Wenderski, T.; Light, K. M.; Ogrin, D.; Bott, S. G.; Harlan, C. J. Tetrahedron Lett. 2004, 45, 6851-6853.

(6) Arduengo, A. J., III; Krafczyk, R.; Schmutzler, R.; Craig, H. A.; Goerlich, J. R.; Marshall, W. J.; Unverzagt, M. Tetrahedron 1999, 55, 14523-14534.

(7) 34a-CI has already isolated by another route. see; Hinchliffe, A.; Mair, F. S.; McInnes, E. J. L.; Pritchard, R. G.; Warren, J. E., Dalton Trans. 2007, 222-233.

(8) Altomare, A.; Burla, M. C.; Camalli, M.; Cascarano, G. L.; Giacovazzo, C.; Guagliardi, A.; Moliterni, A. G. G.; Polidori, G.; Spagna, R. J. Appl. Cryst. 1999, 32, 115-119.

(9) Sheldrick, G. M.; University of Göttingen: Göttingen, Germany, 1997.

(10) Frisch, M. J.; Trucks, G. W.; Schlegel, H. B.; Scuseria, G. E.; Robb, M. A.; Cheeseman, J. R.; Montgomery, J., J. A.; Vreven, T.; Kudin, K. N.; Burant, J. C.; Millam, J. M.; Iyengar, S. S.; Tomasi, J.; Barone, V.; Mennucci, B.; Cossi, M.; Scalmani, G.; Rega, N.; Petersson, G. A.; Nakatsuji, H.; Hada, M.; Ehara, M.; Toyota, K.; Fukuda, R.; Hasegawa, J.; Ishida, M.; Nakajima, T.; Honda, Y.; Kitao, O.; Nakai, H.; Klene, M.; Li, X.; Knox, J. E.; Hratchian, H. P.; Cross, J. B.; Bakken, V.; Adamo, C.; Jaramillo, J.; Gomperts, R.; Stratmann, R. E.; Yazyev, O.; Austin, A. J.; Cammi, R.; Pomelli, C.; Ochterski, J. W.; Ayala, P. Y.; Morokuma, K.; Voth, G. A.; Salvador, P.; Dannenberg, J. J.; Zakrzewski, V. G.; Dapprich, S.; Daniels, A. D.; Strain, M. C.; Farkas, O.; Malick, D. K.; Rabuck, A. D.; Raghavachari, K.; Foresman, J. B.; Ortiz, J. V.; Cui, Q.; Baboul, A. G.; Clifford, S.; Cioslowski, J.; Stefanov, B. B.; Liu, G.; Liashenko, A.; Piskorz, P.; Komaromi, I.; Martin, R. L.; Fox, D. J.; Keith, T.; Al-Laham, M. A.; Peng, C. Y.; Nanayakkara, A.; Challacombe, M.; Gill, P. M. W.; Johnson, B.; Chen, W.; Wong, M. W.; Gonzalez, C.; Pople, J. A. Gaussian03W, Revision D.01; Gaussian, Inc.: Wallingford CT, 2004.

(11) Biegler-Konig, F.; Schonbohm, J.; Bayles, D. J. Comput. Chem. 2001, 22, 545-559.

(12) Biegler-Konig, F.; Schonbohm, J. J. Comput. Chem. 2002, 23, 1489-1494. 

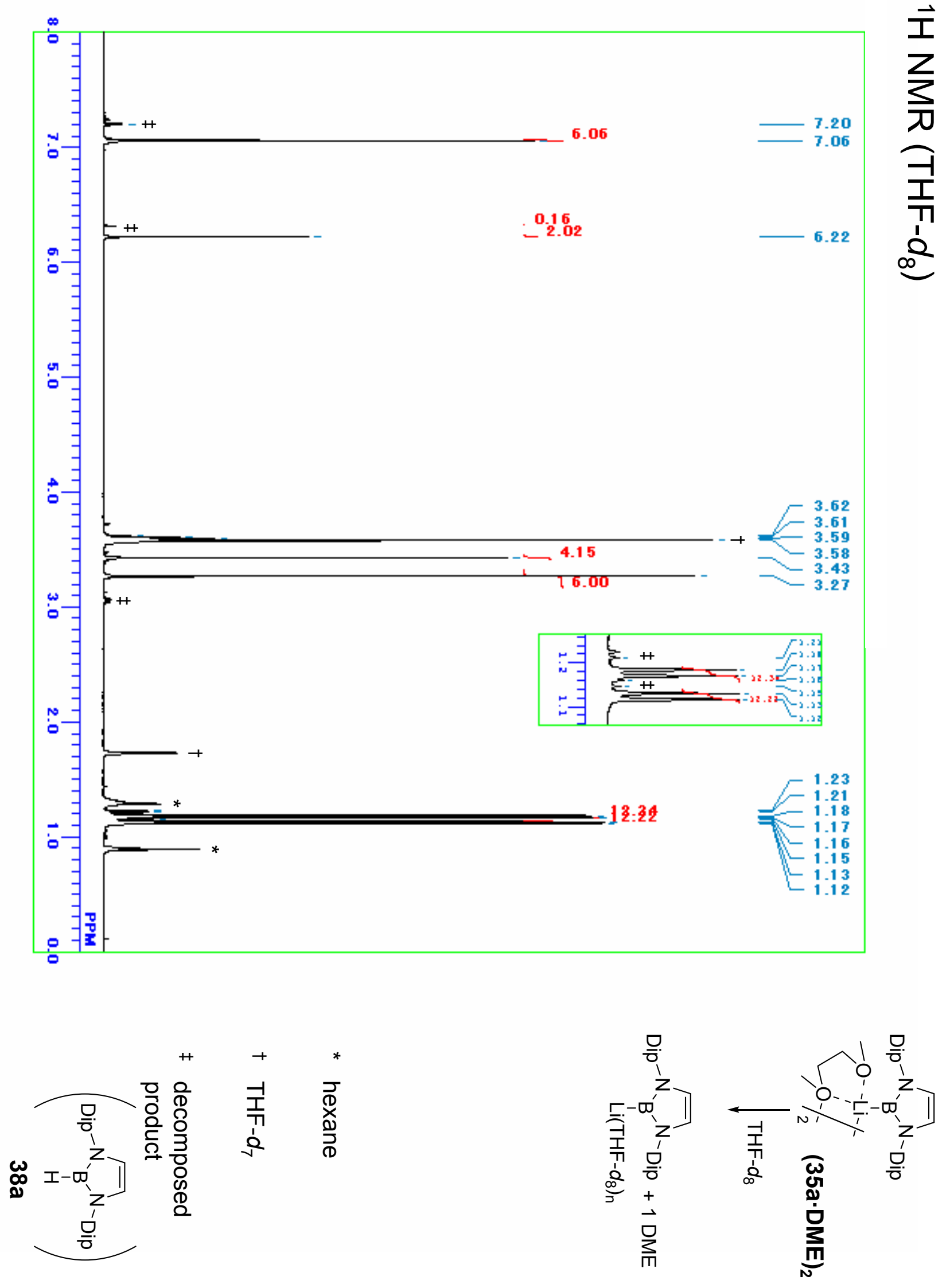

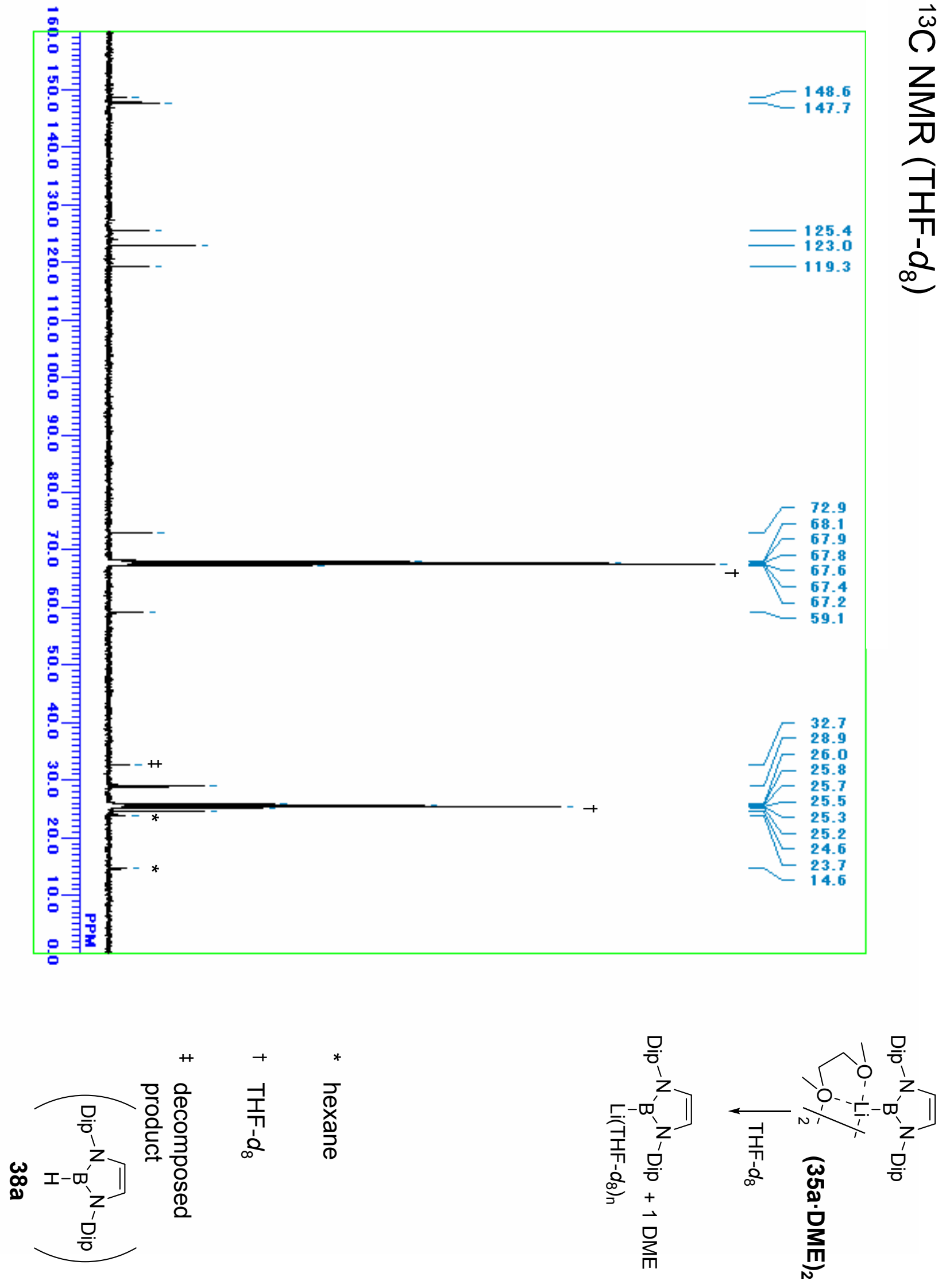


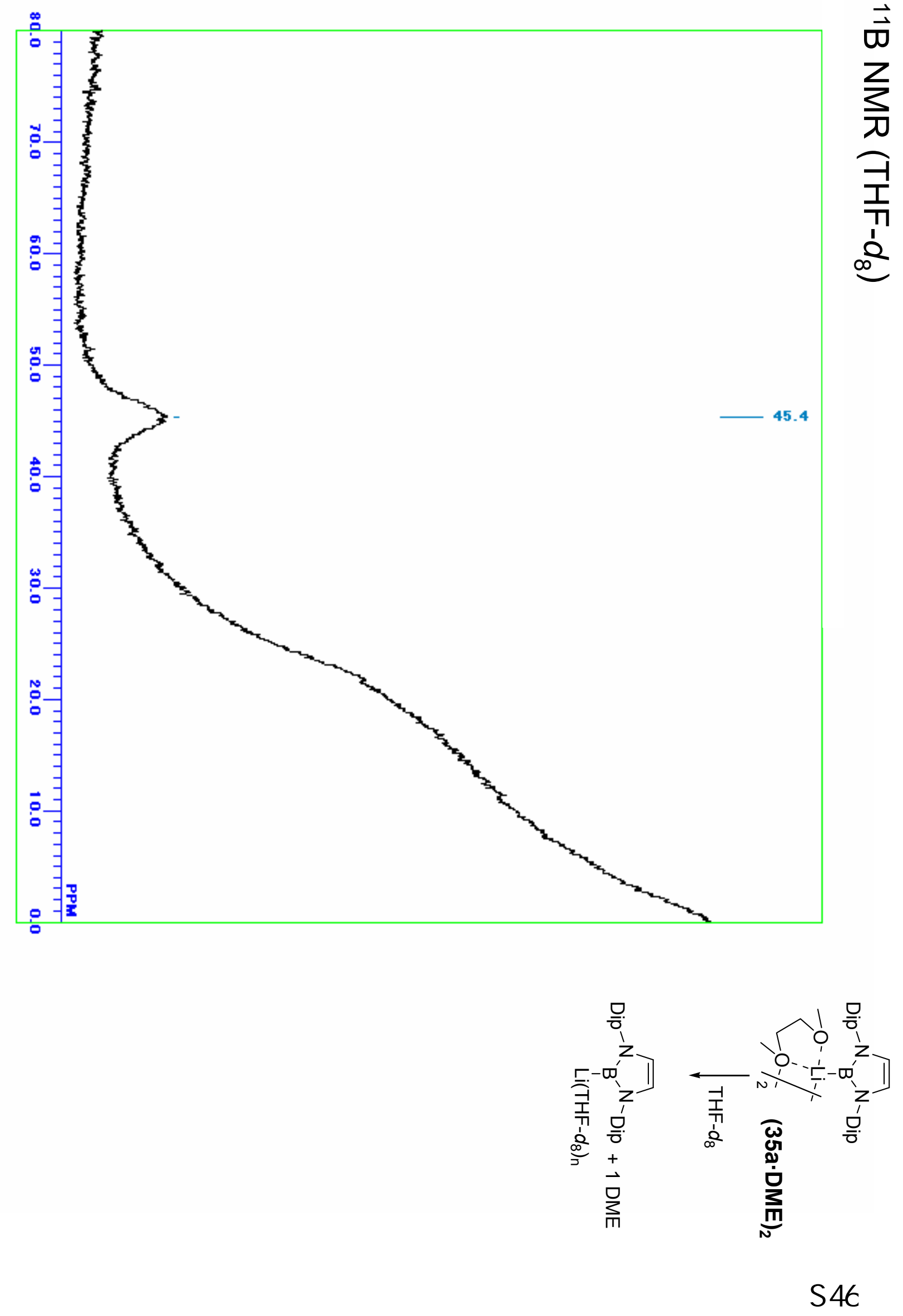



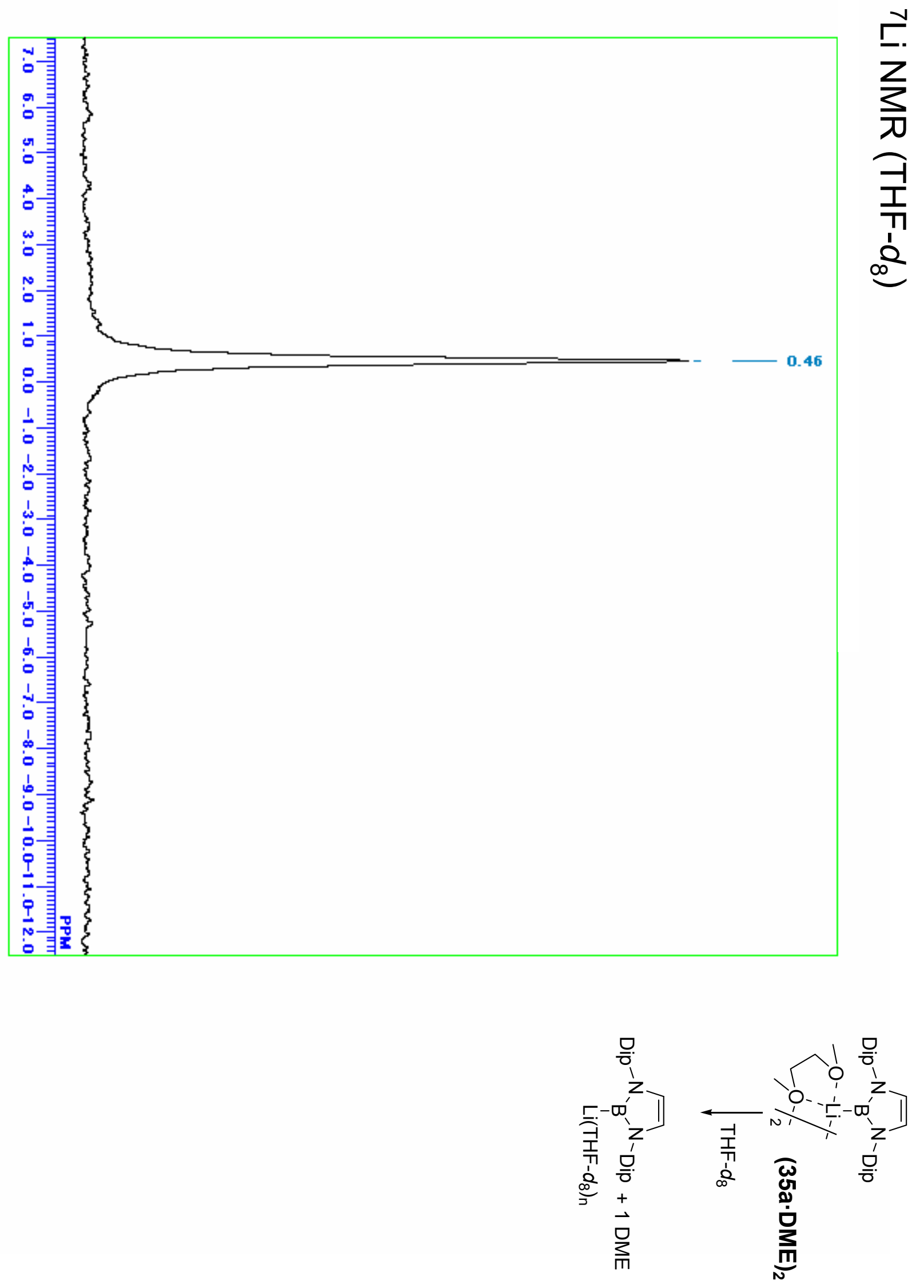

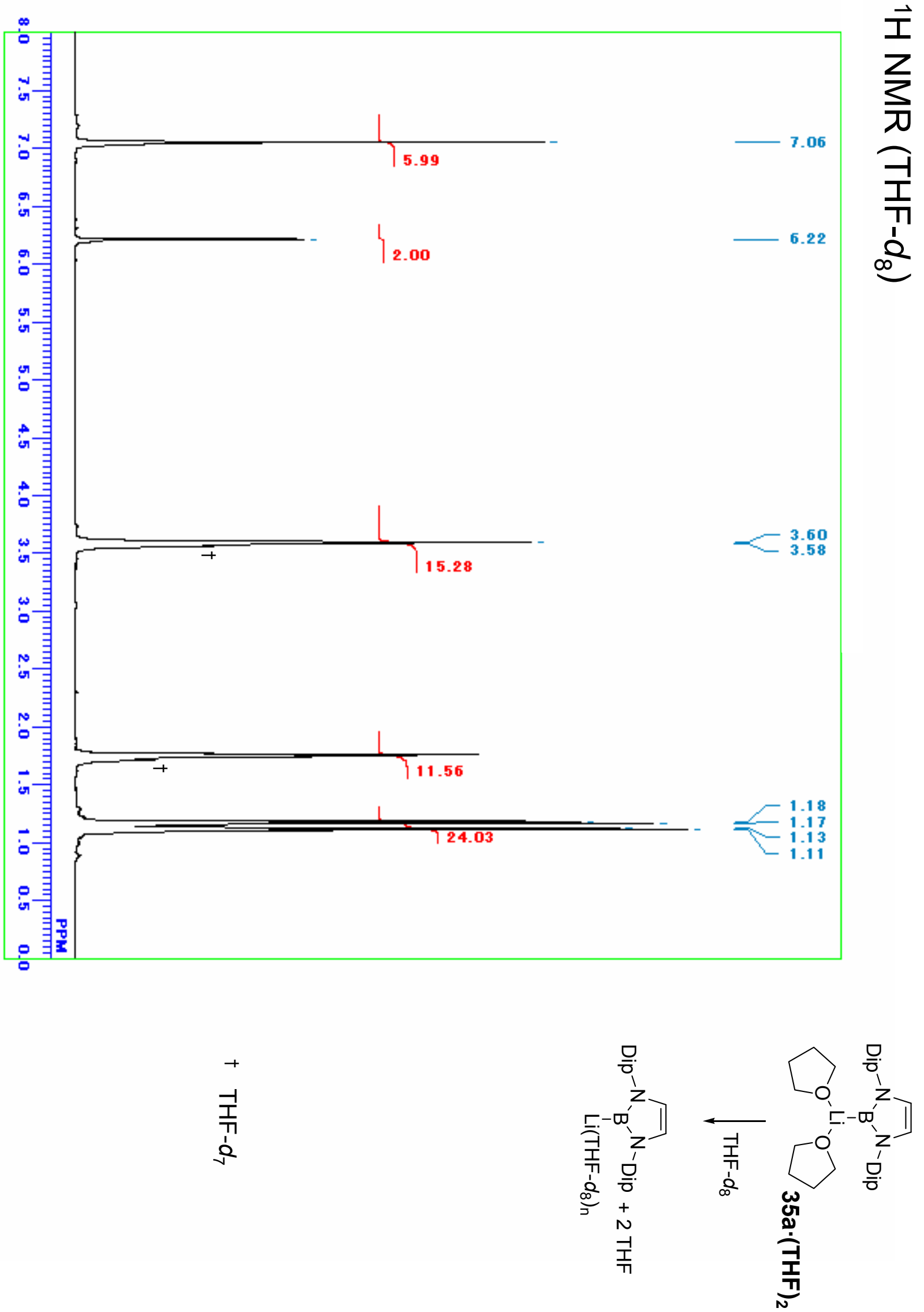

S48 

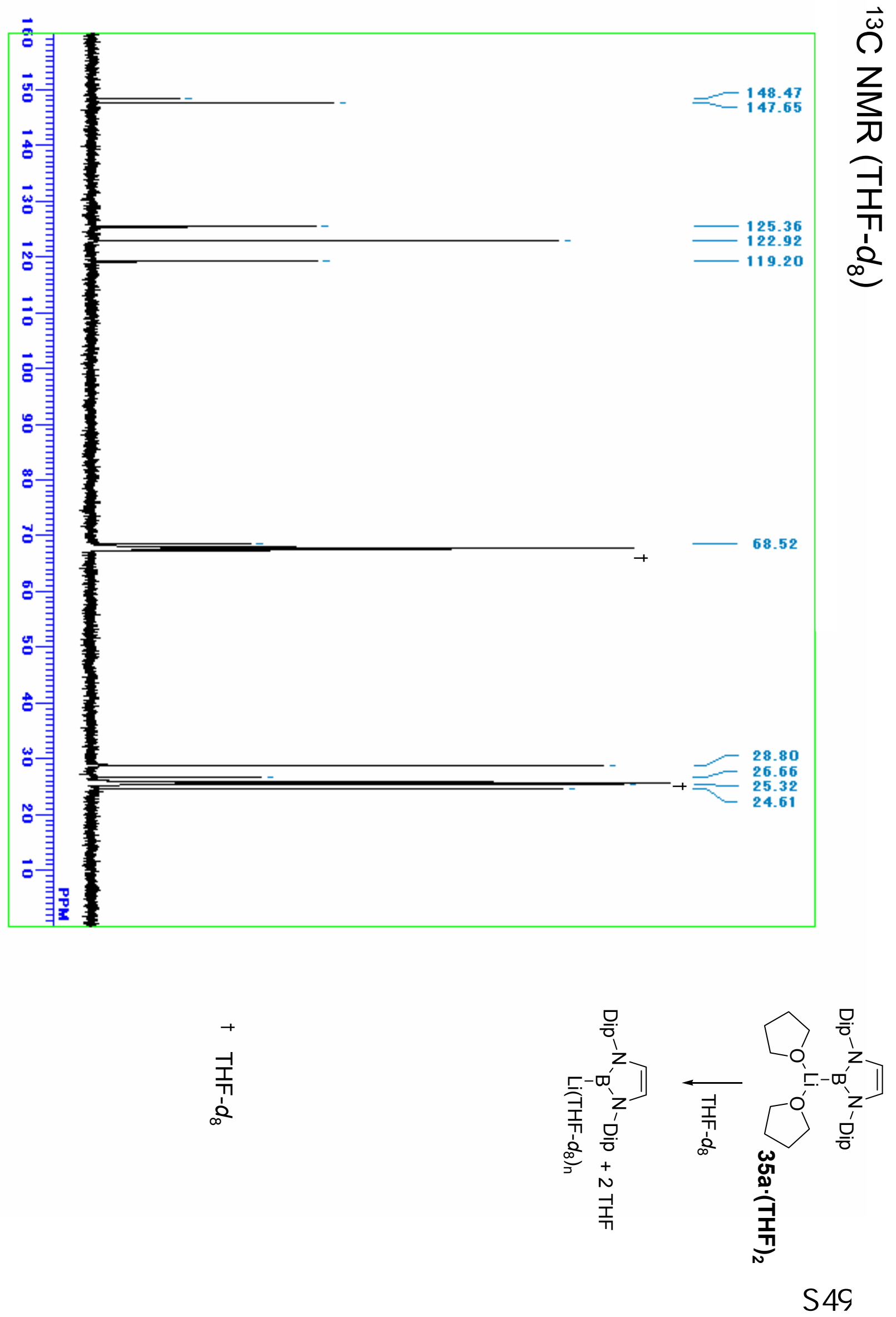


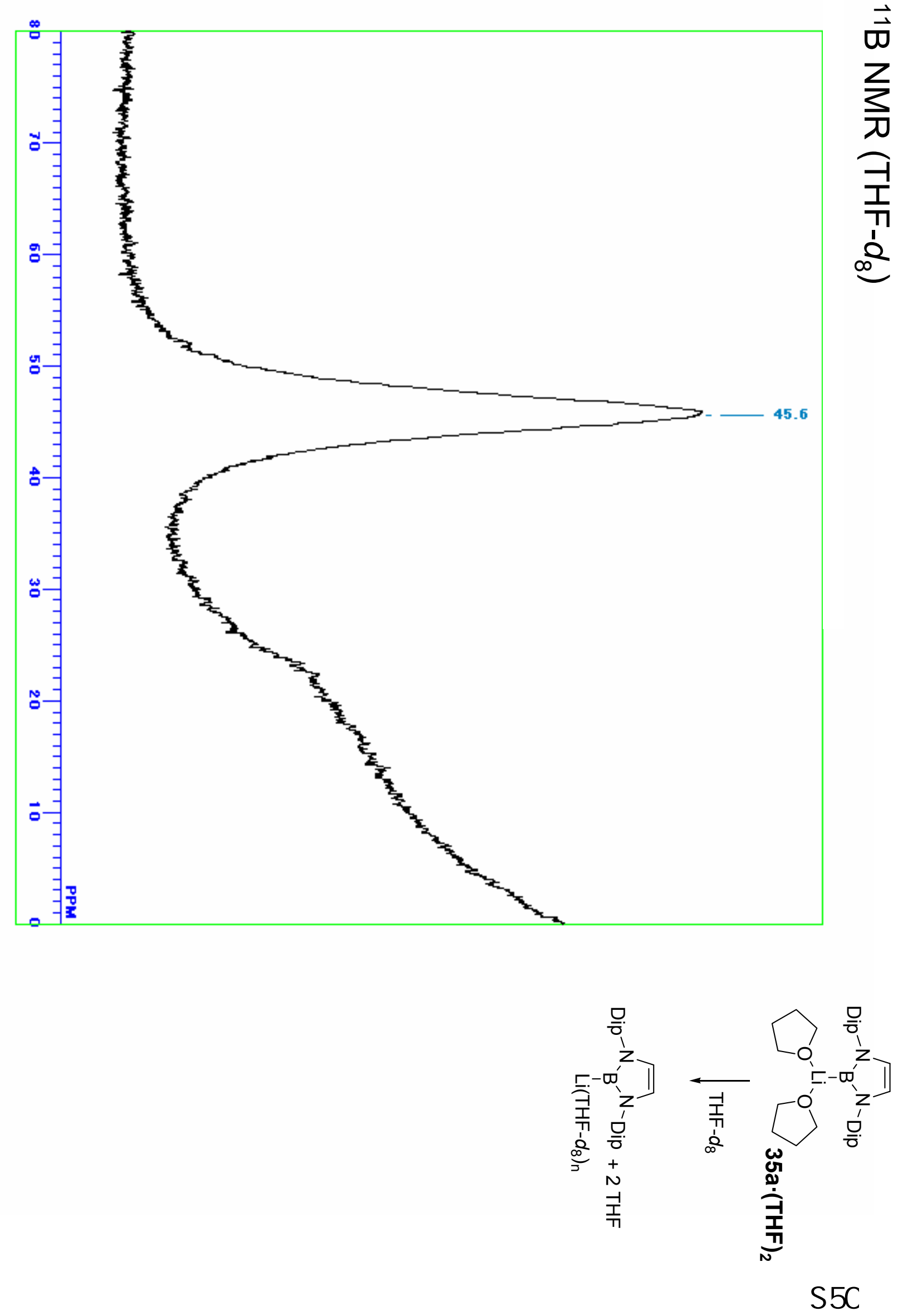



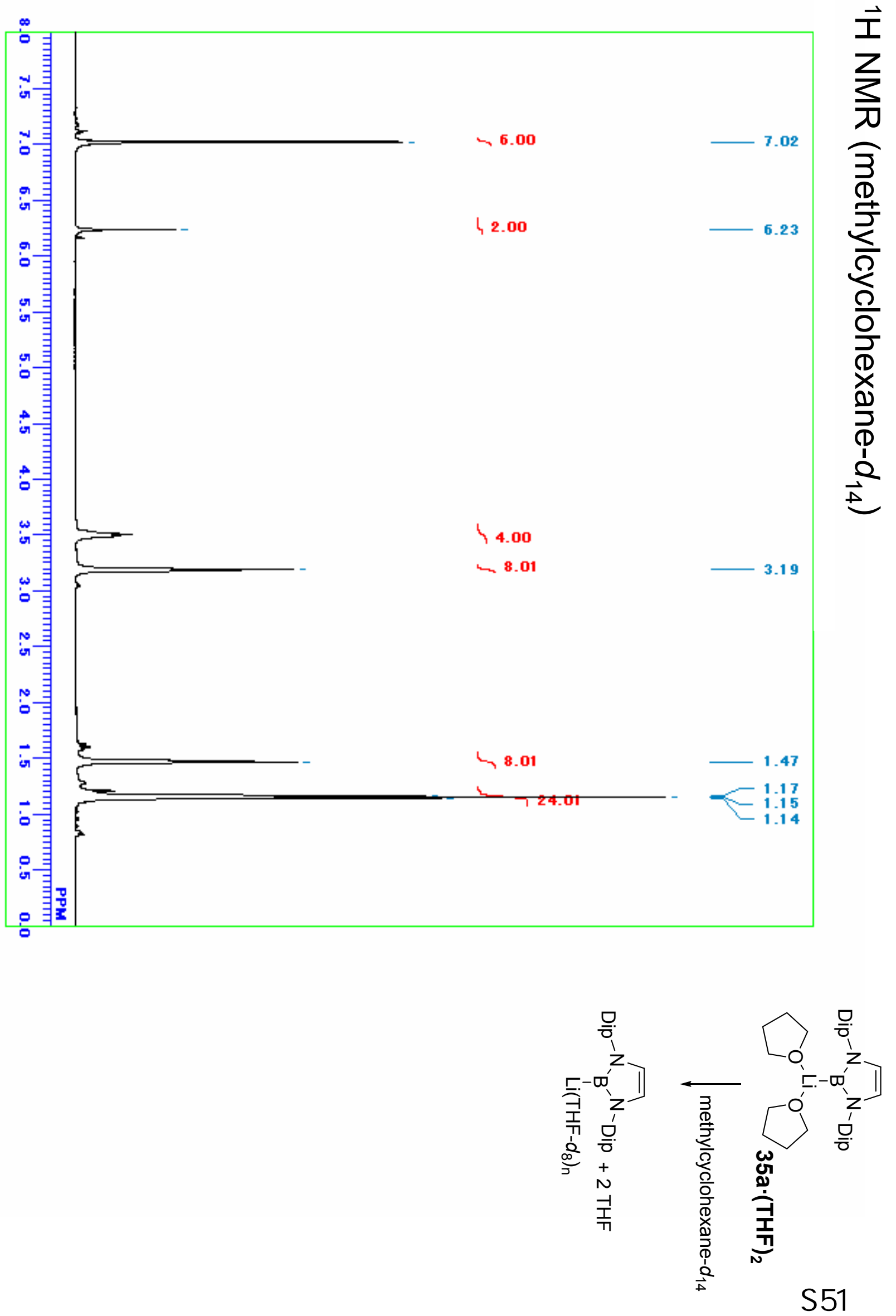


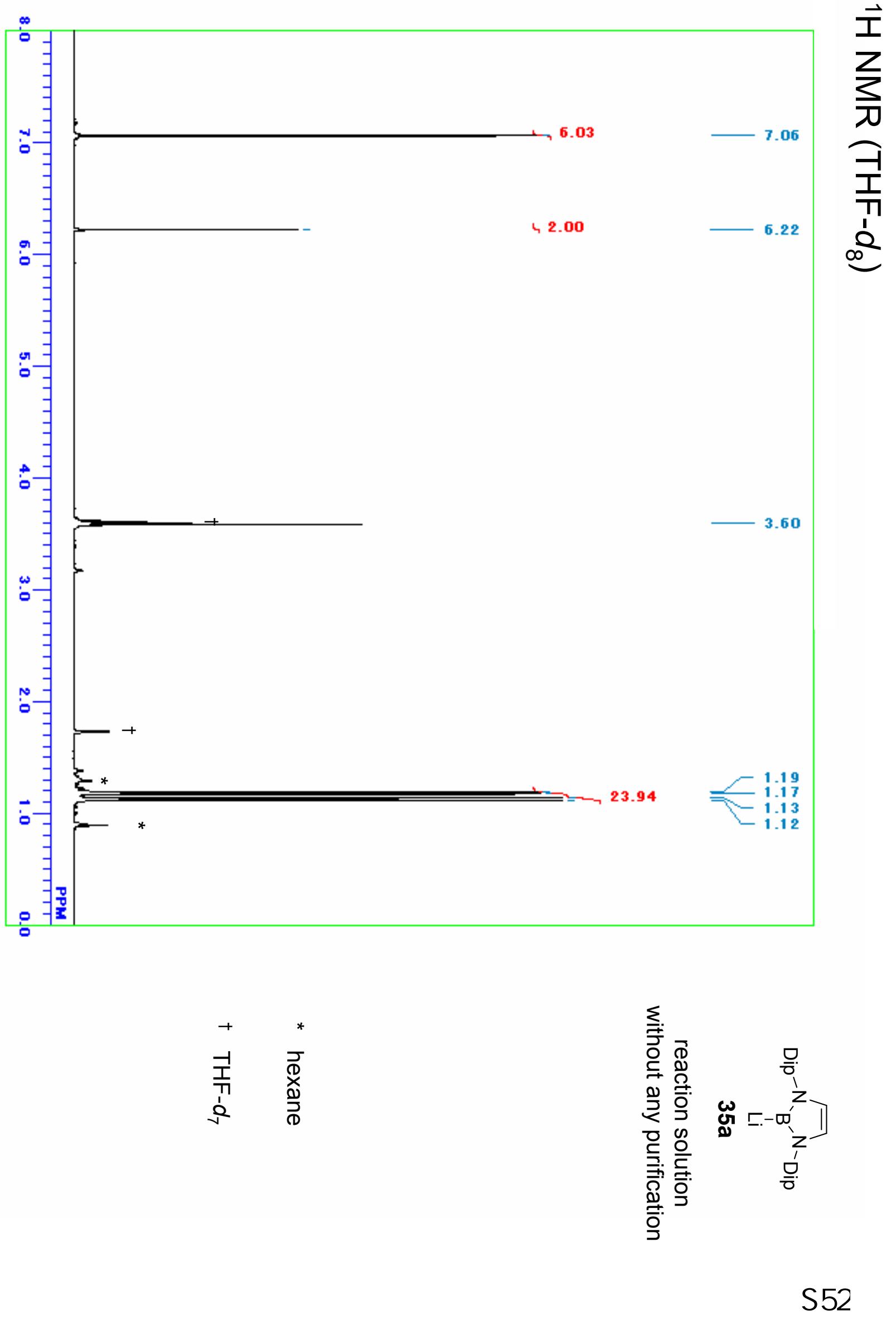




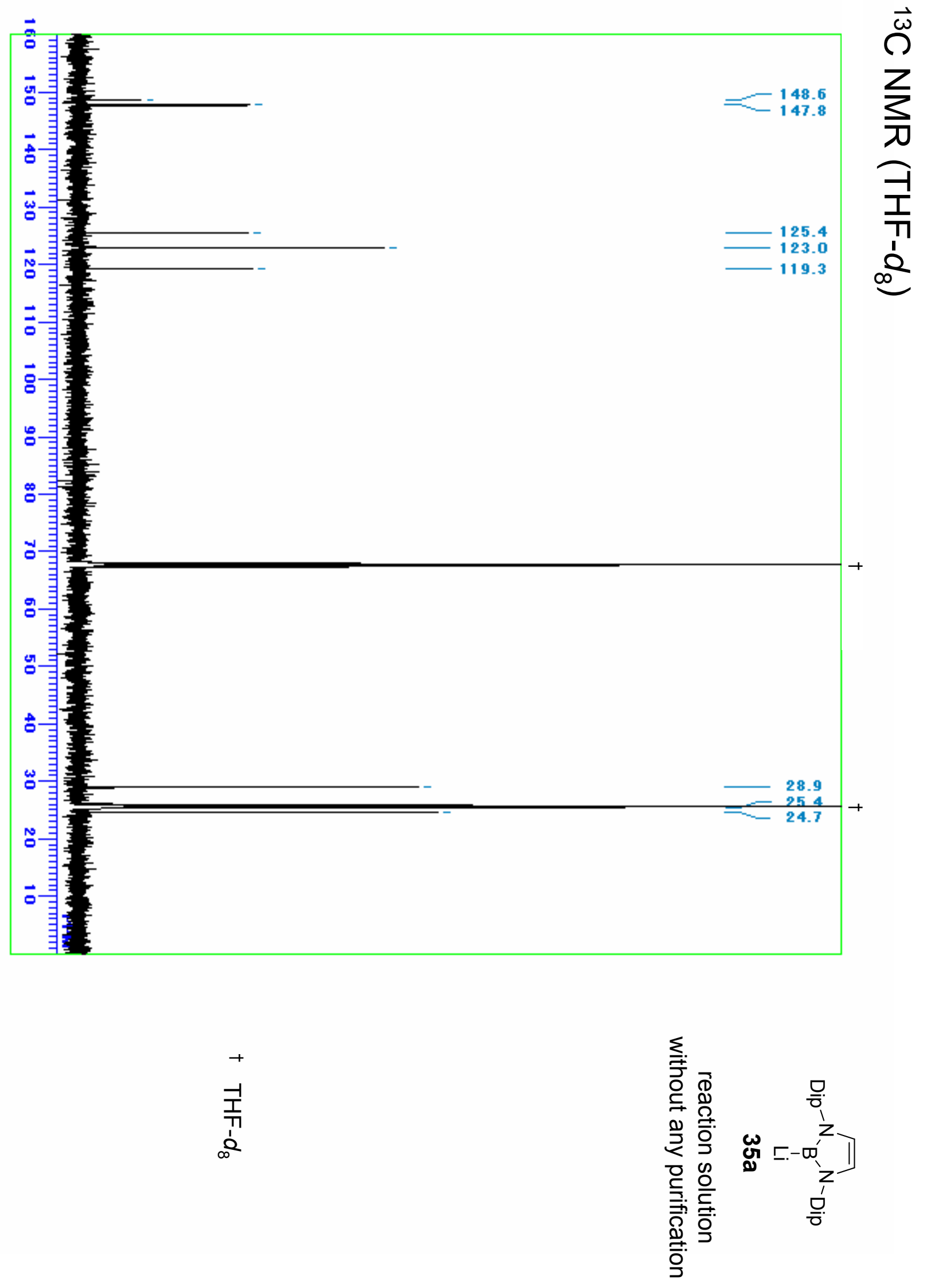

S53 


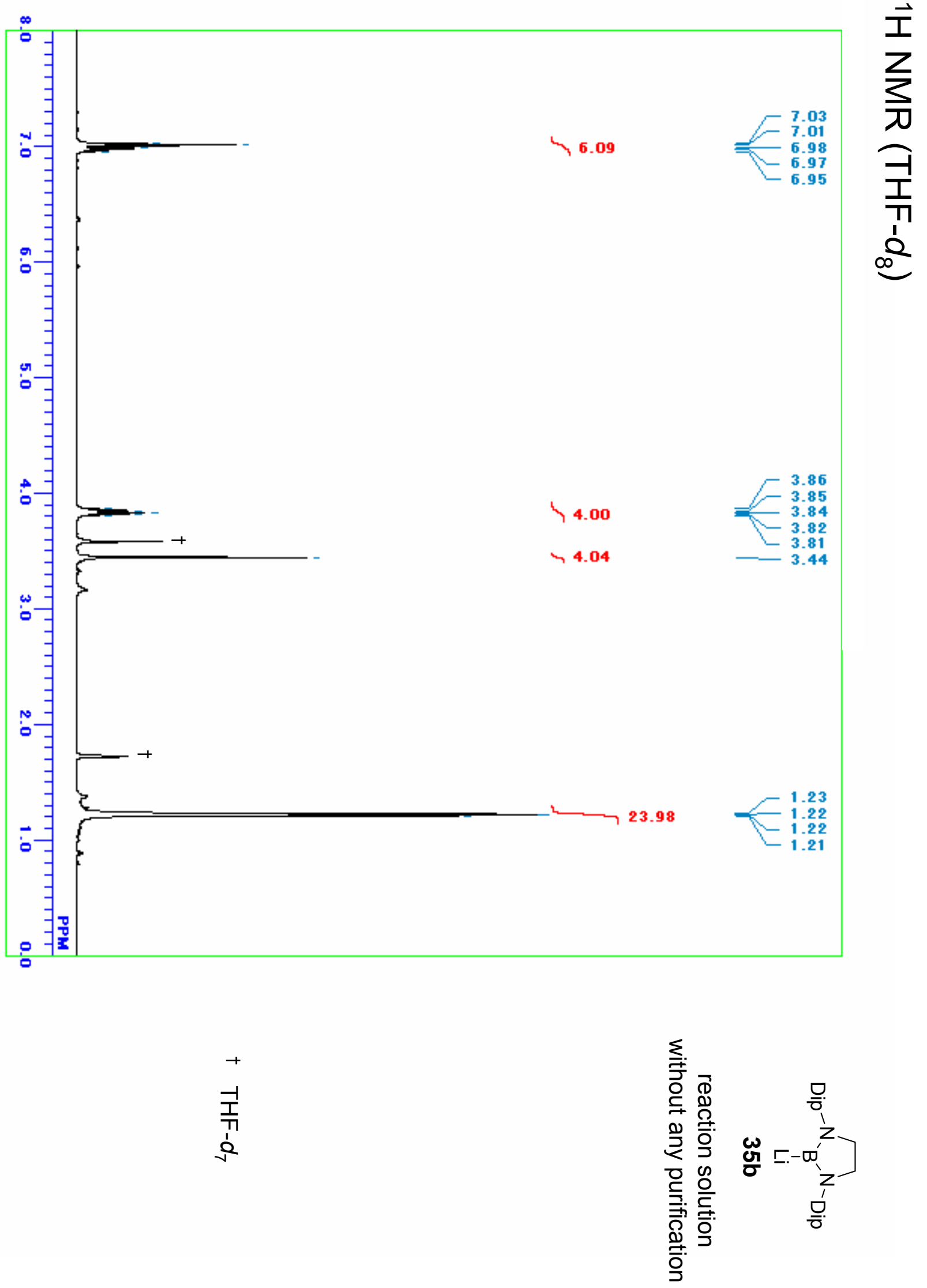




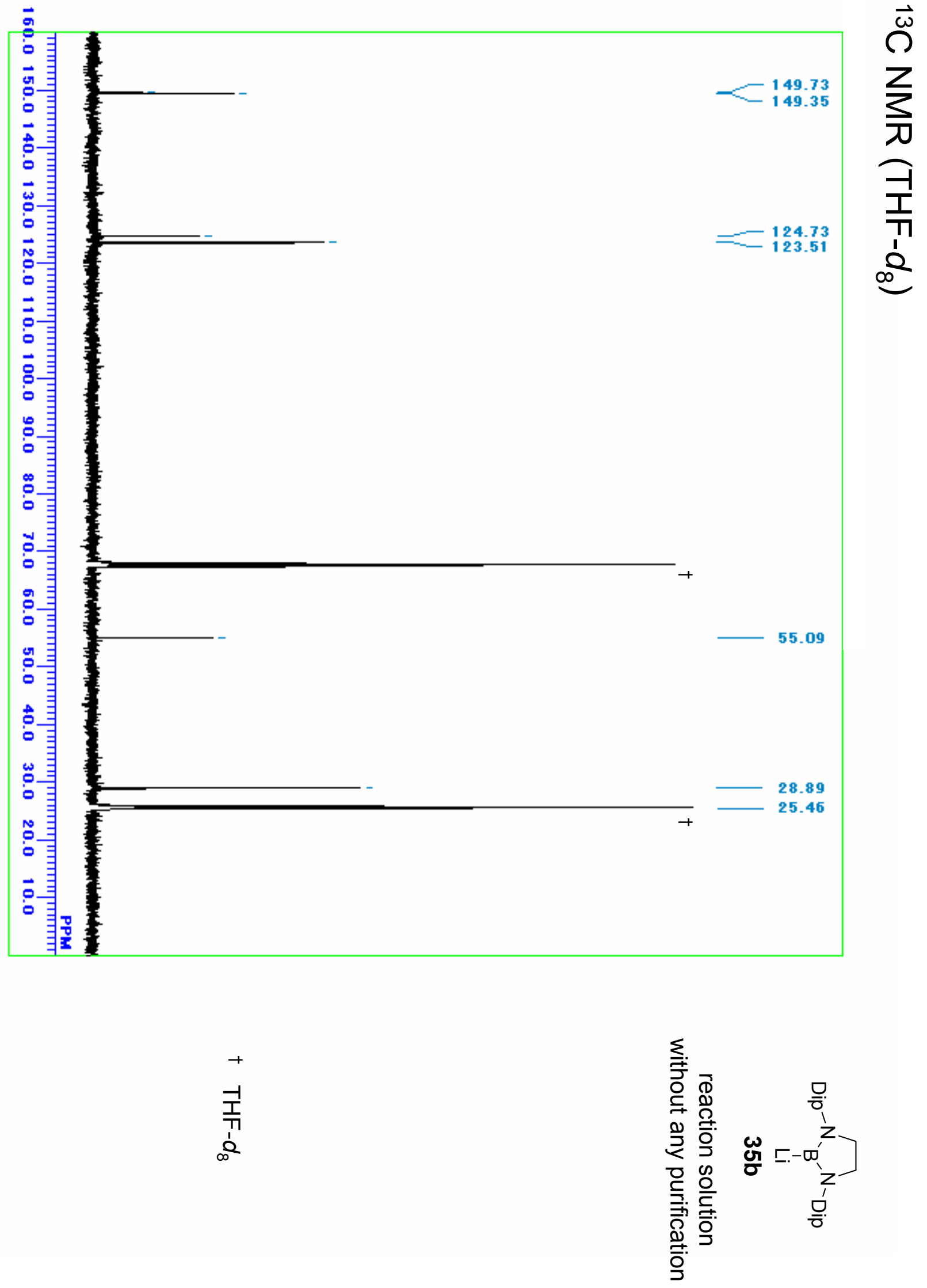




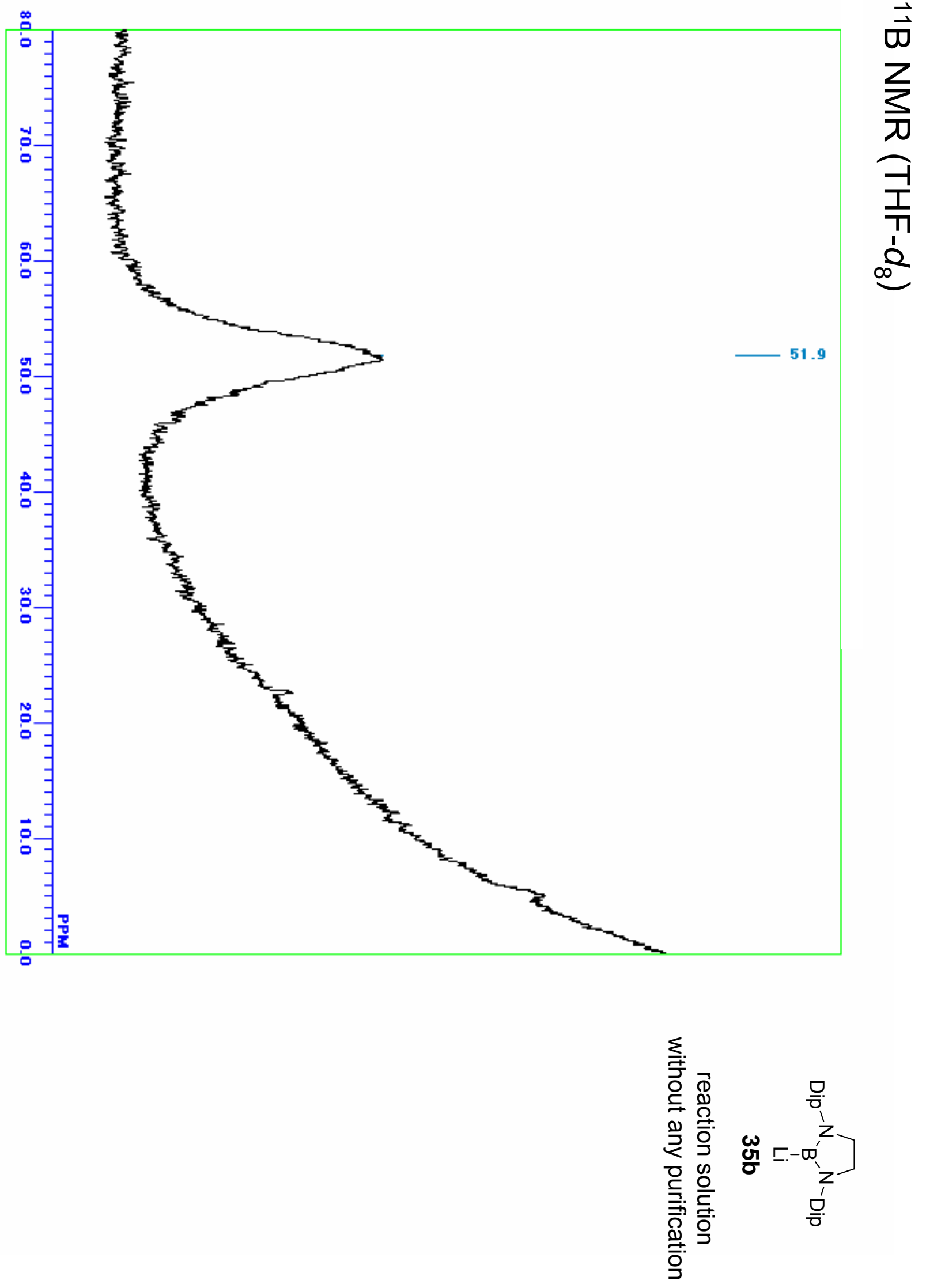




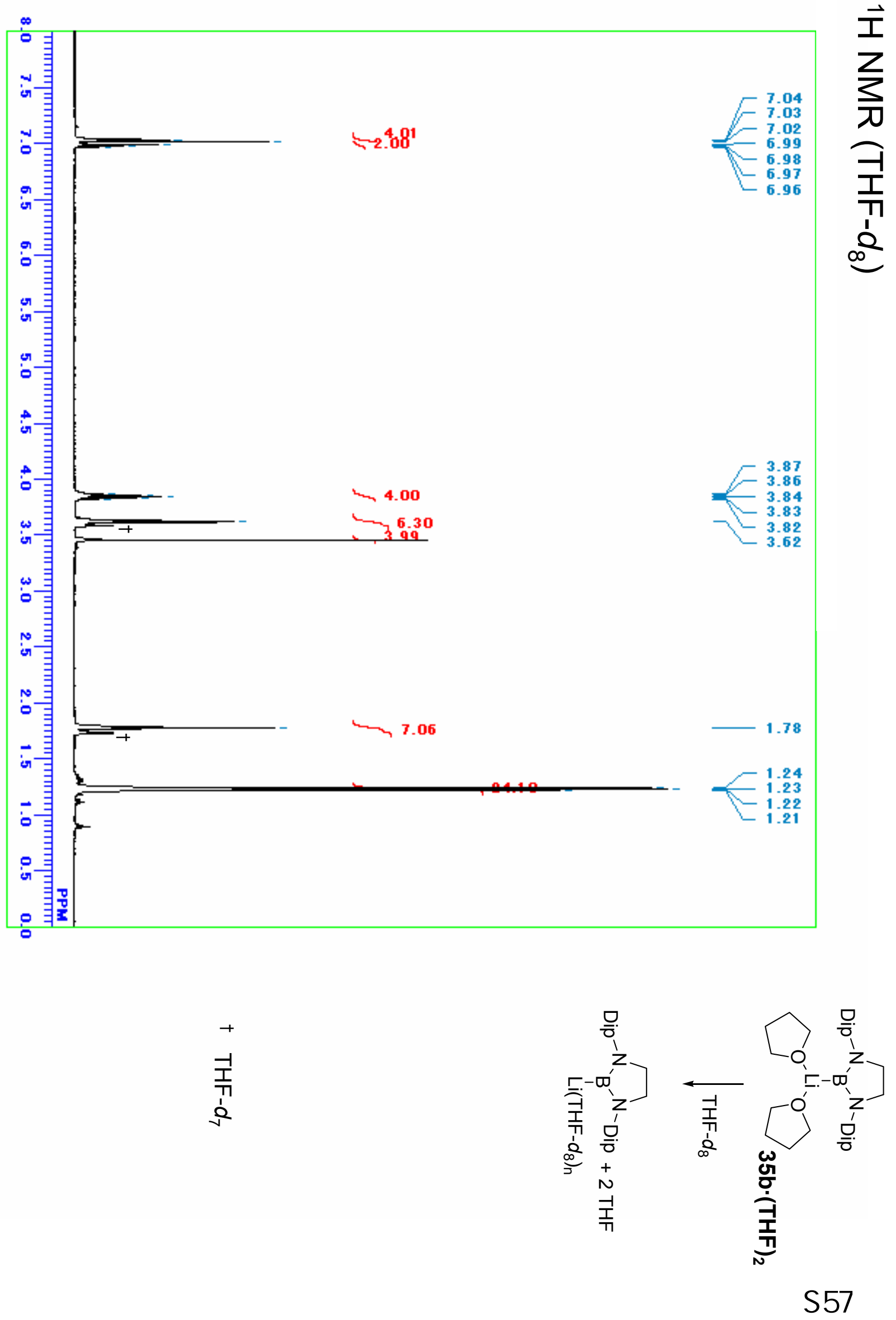



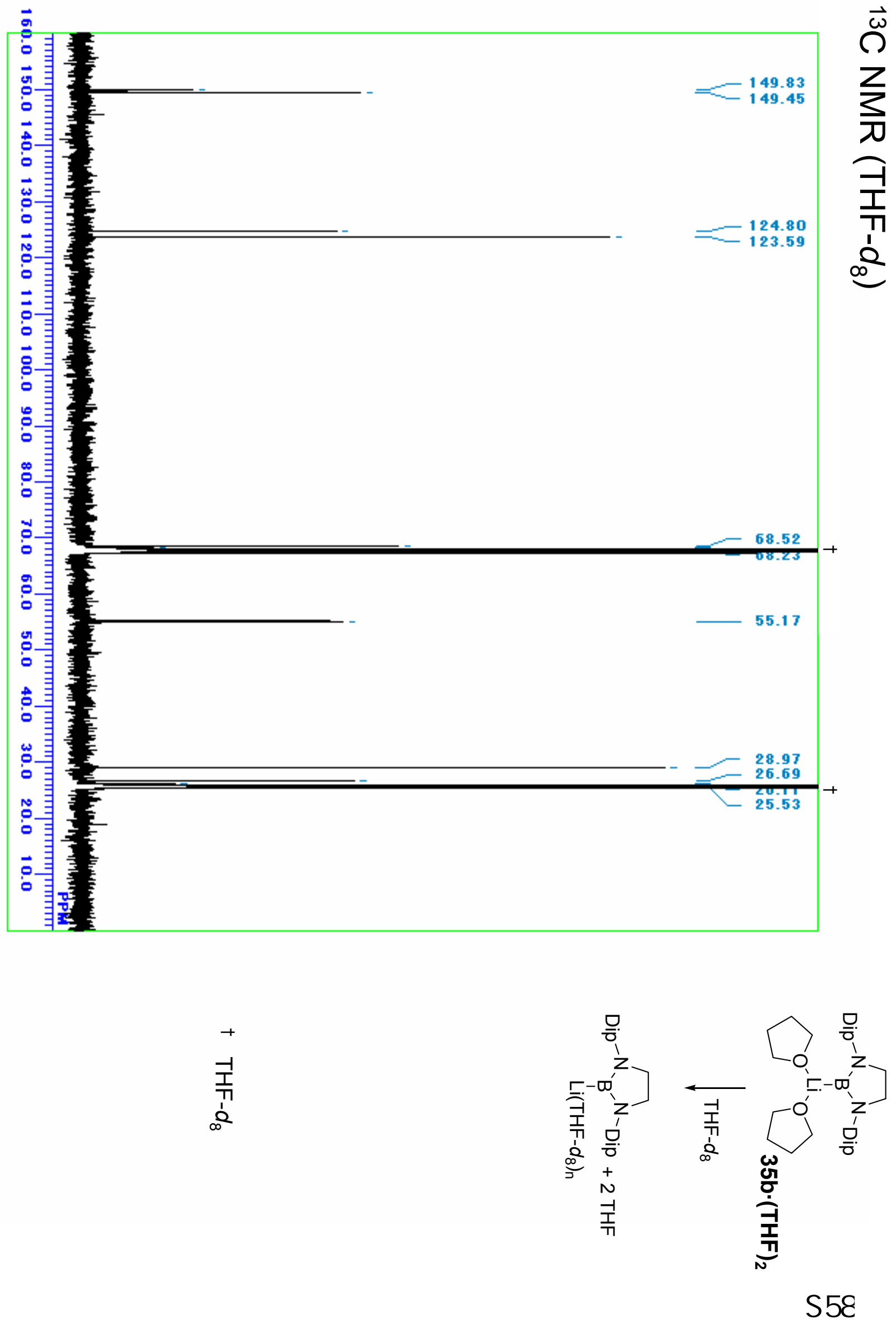


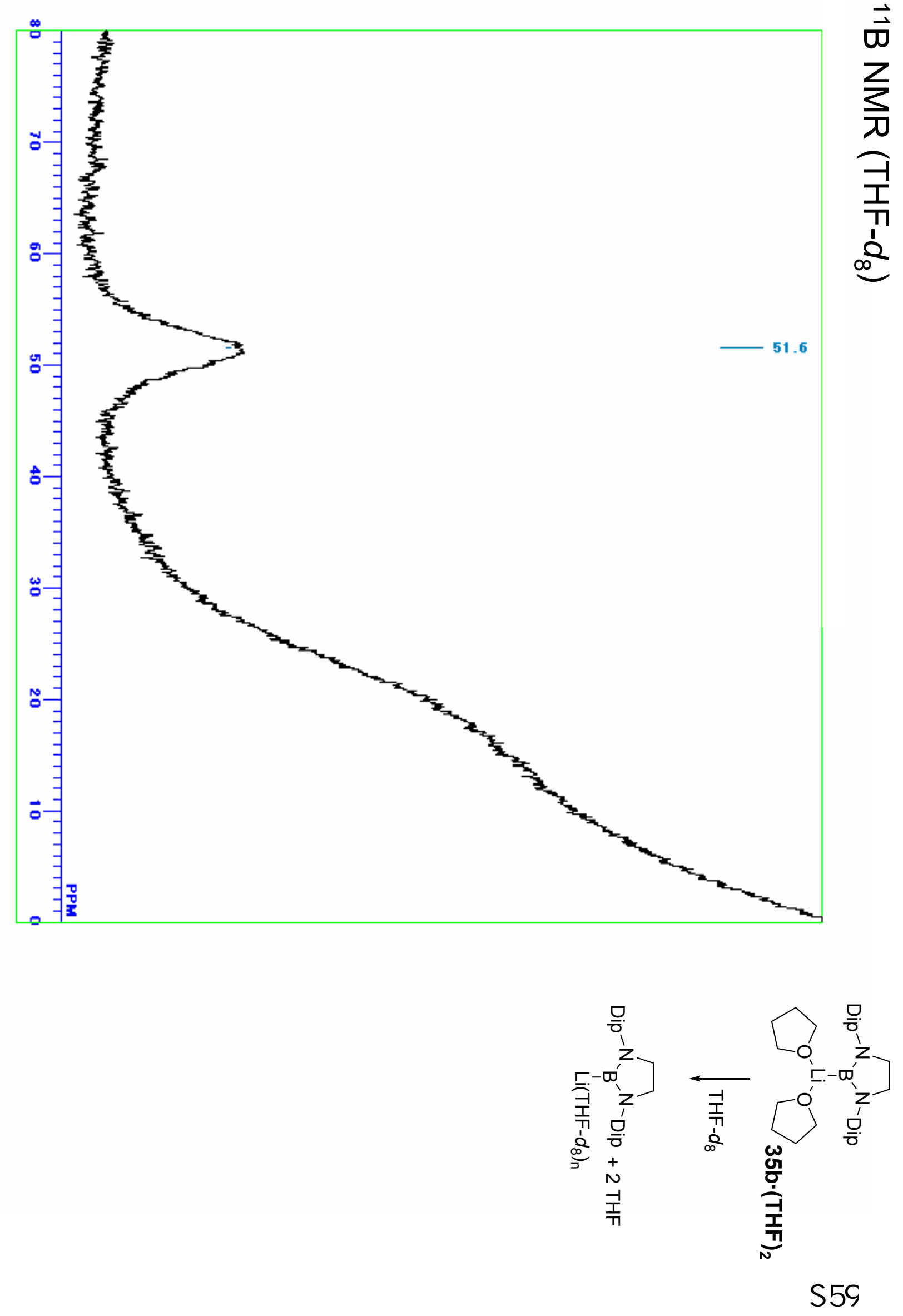




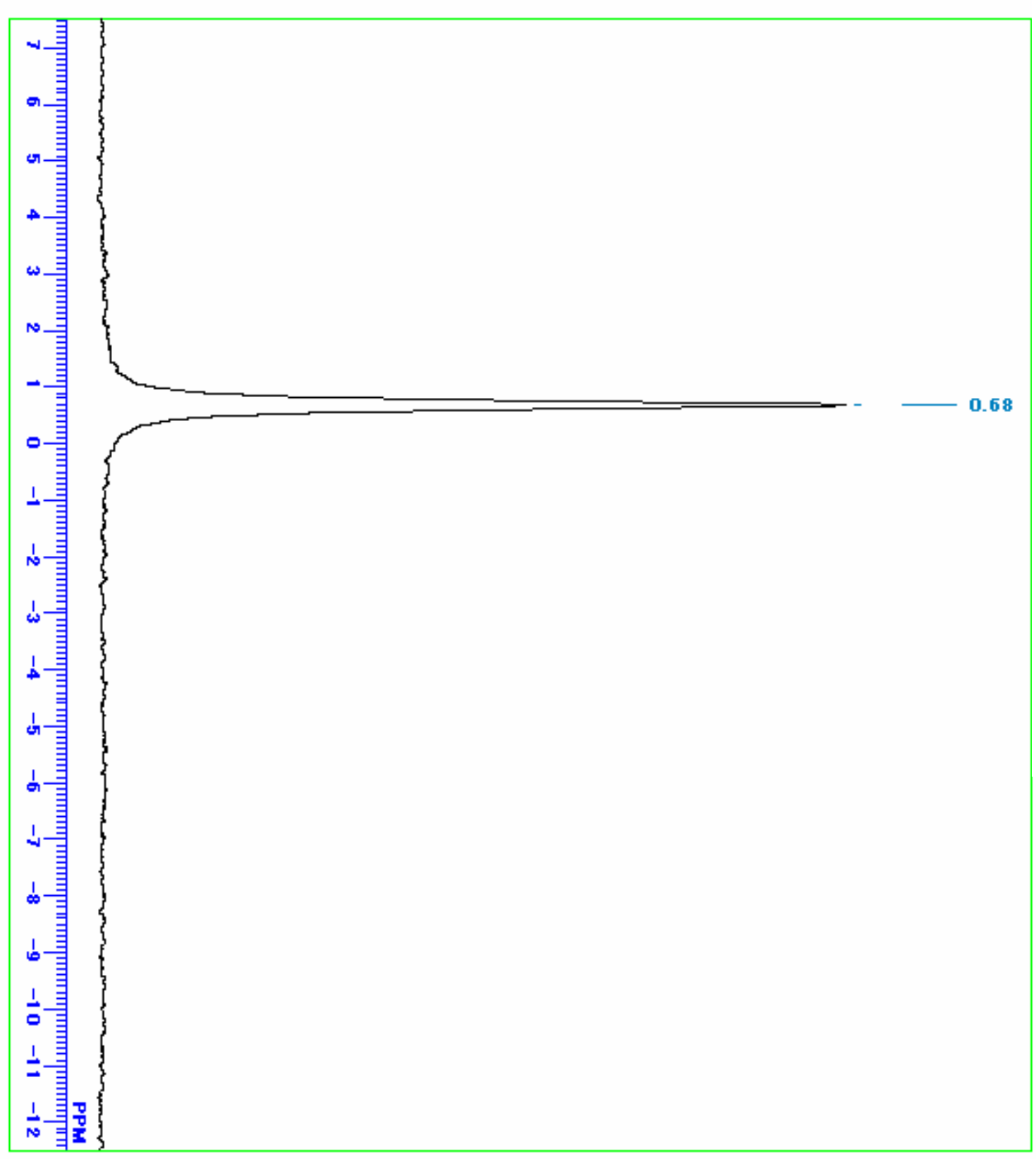

ㄹ.

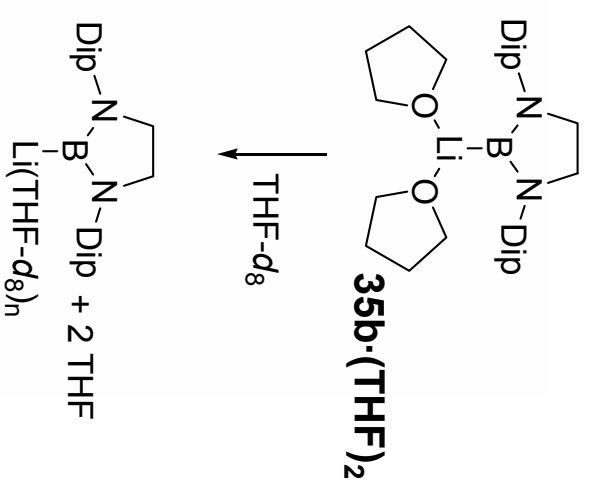

S60 


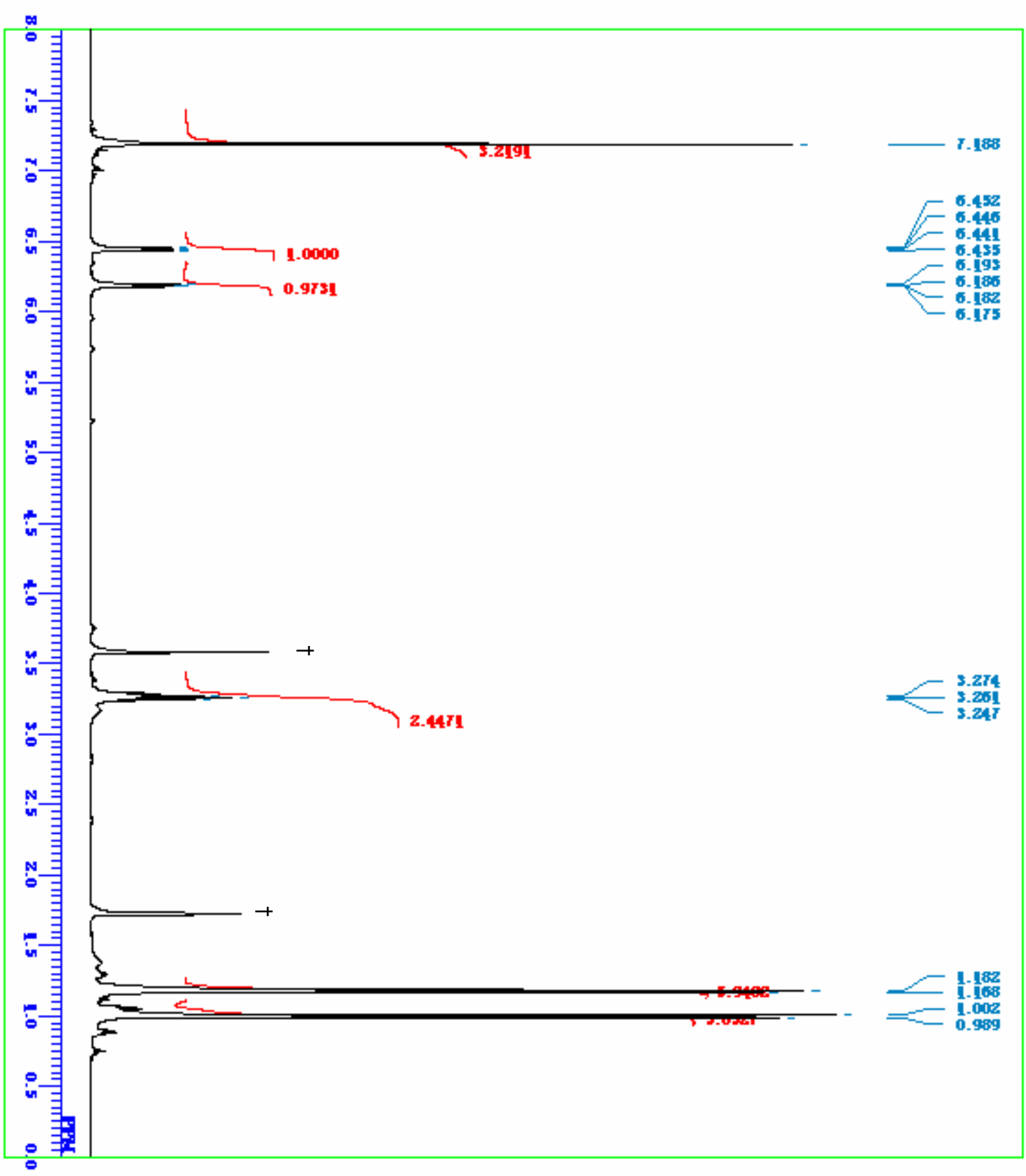

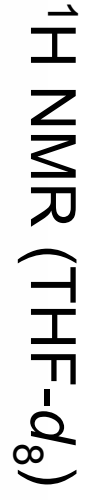

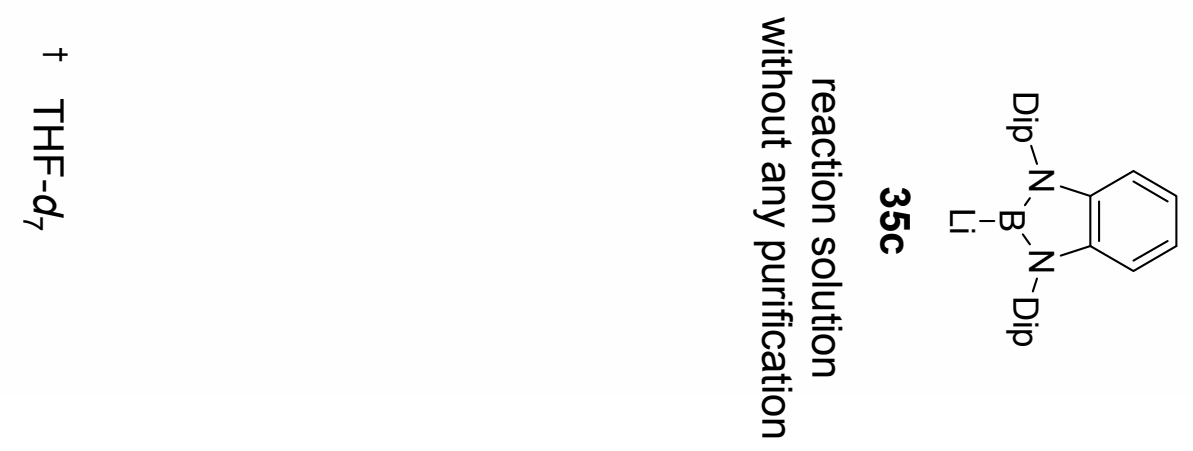

S61 

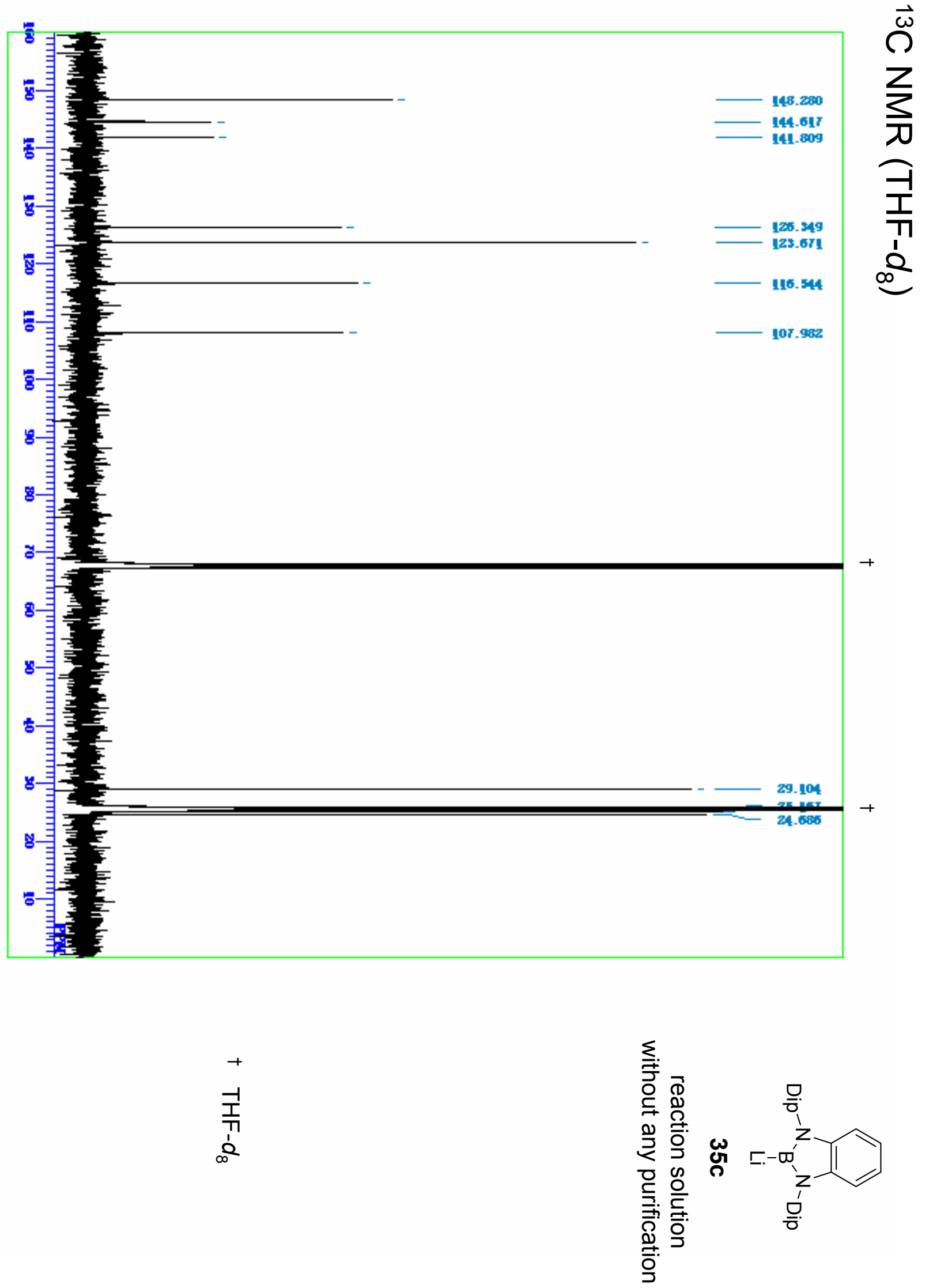


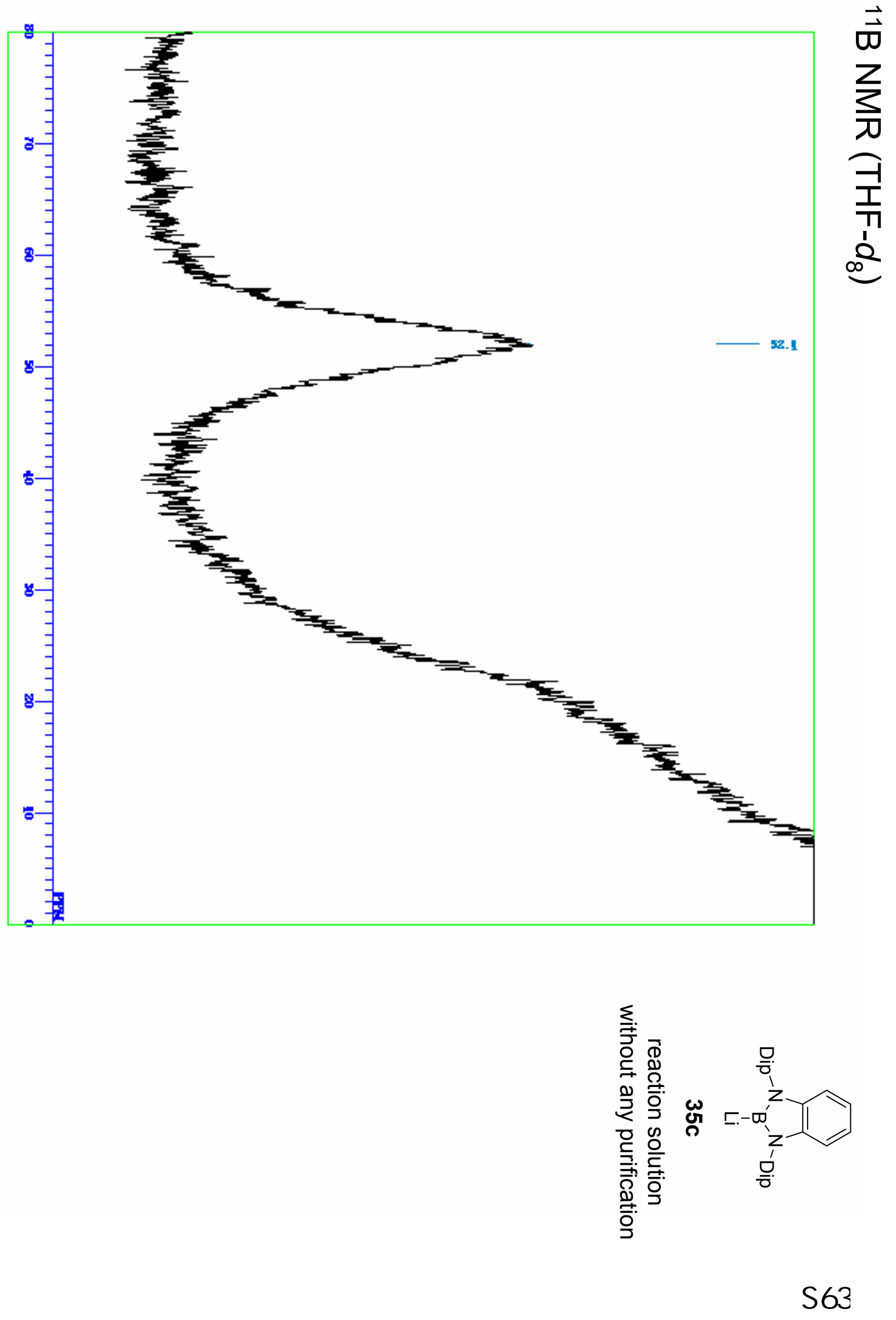




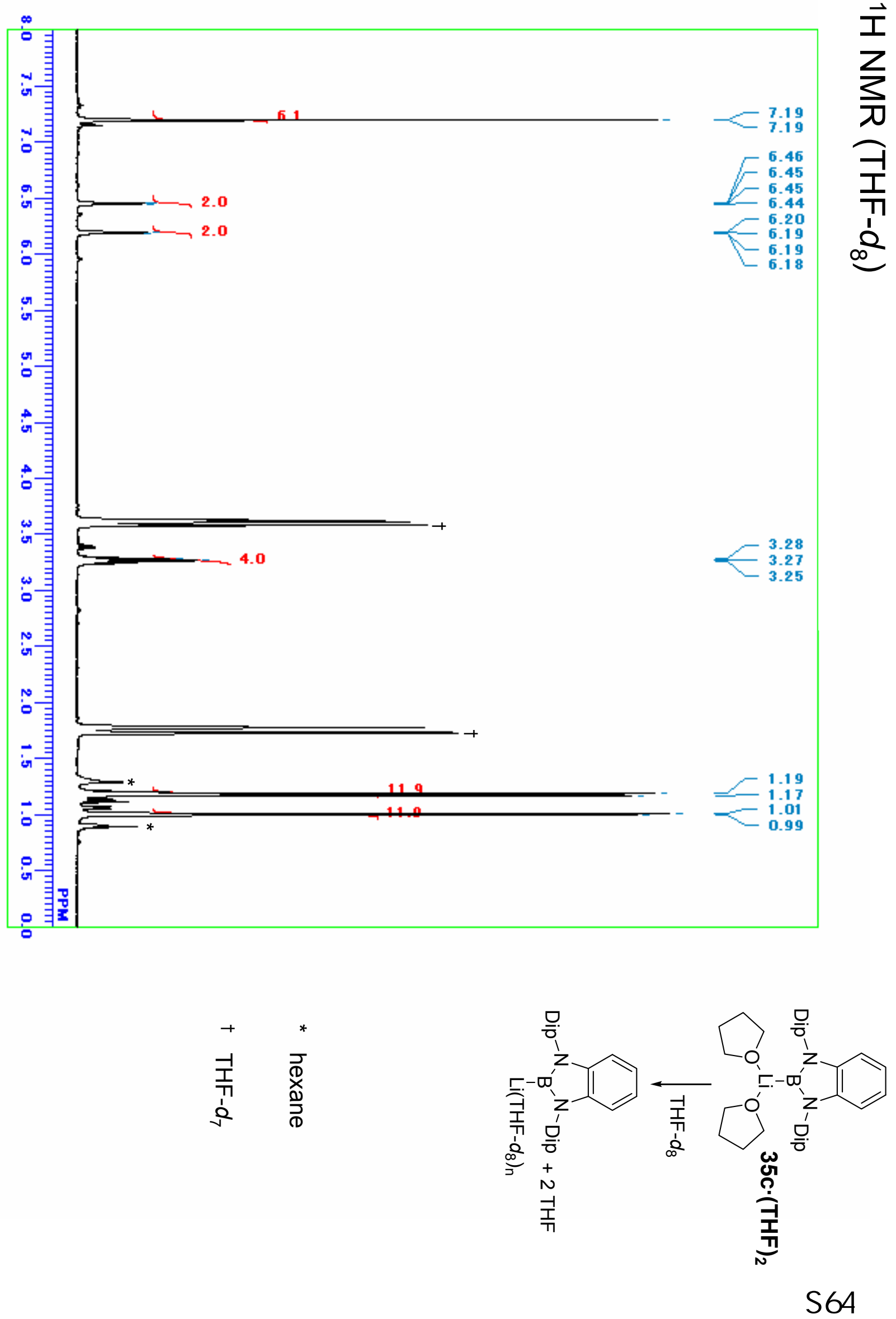



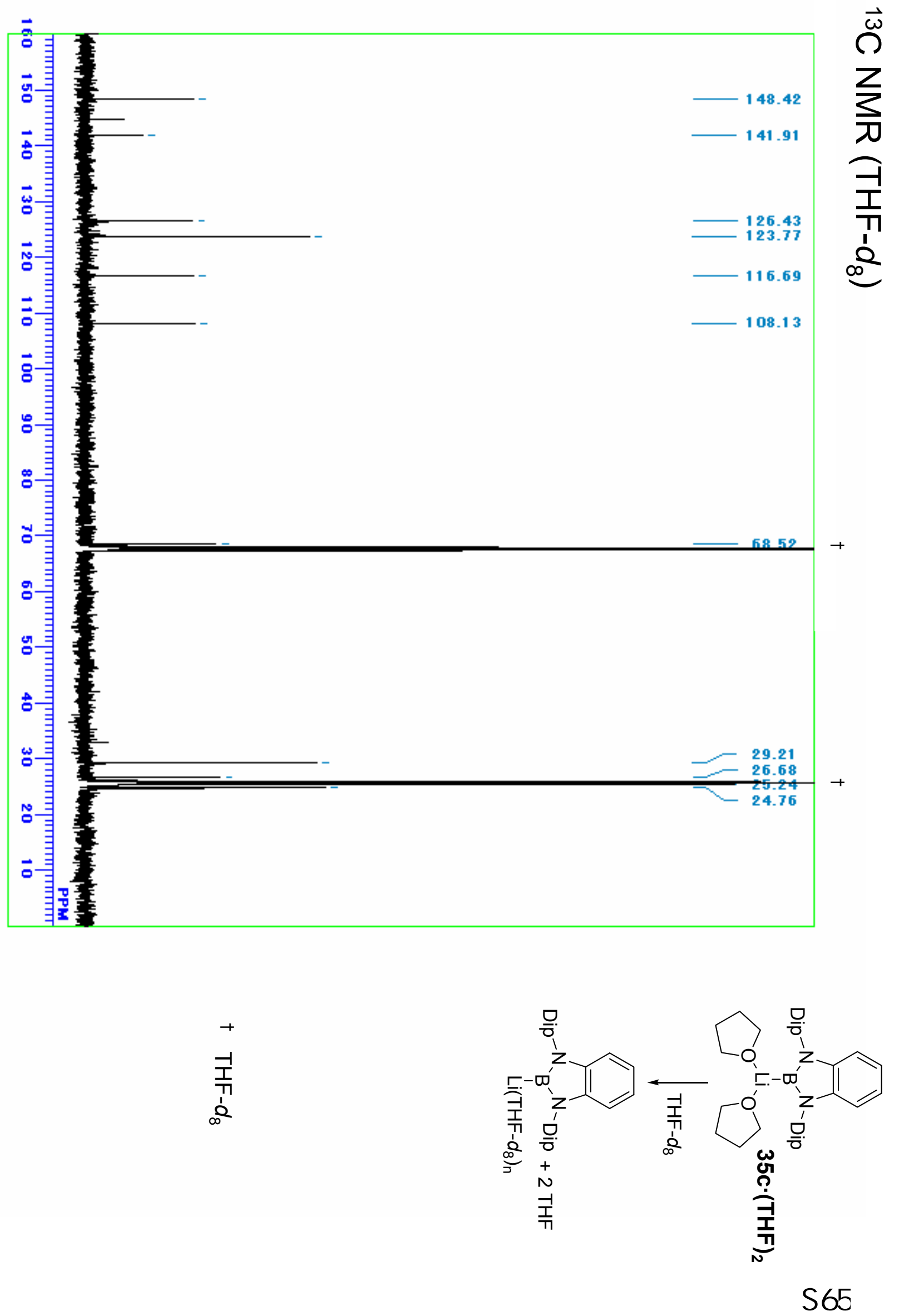

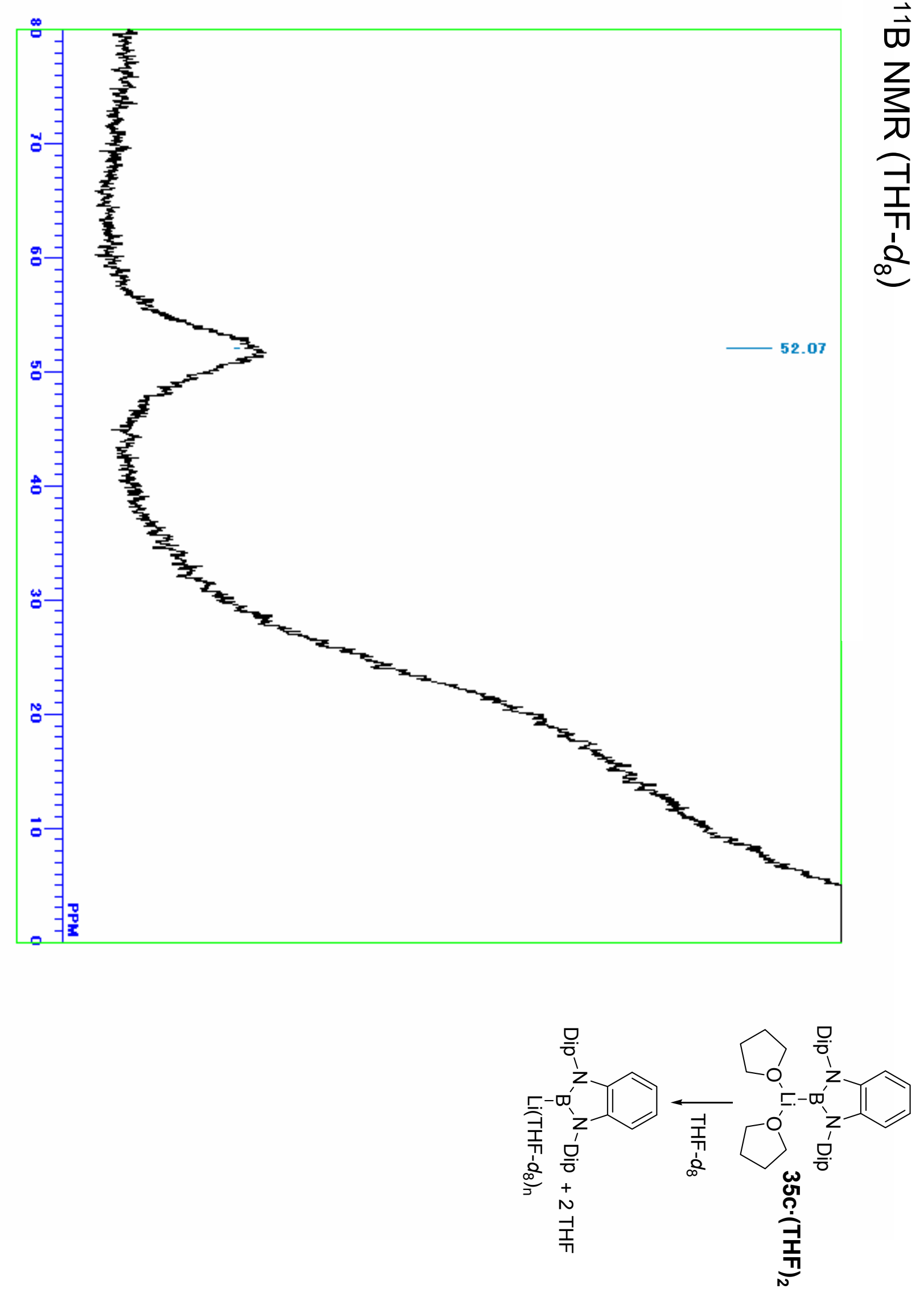

S66 


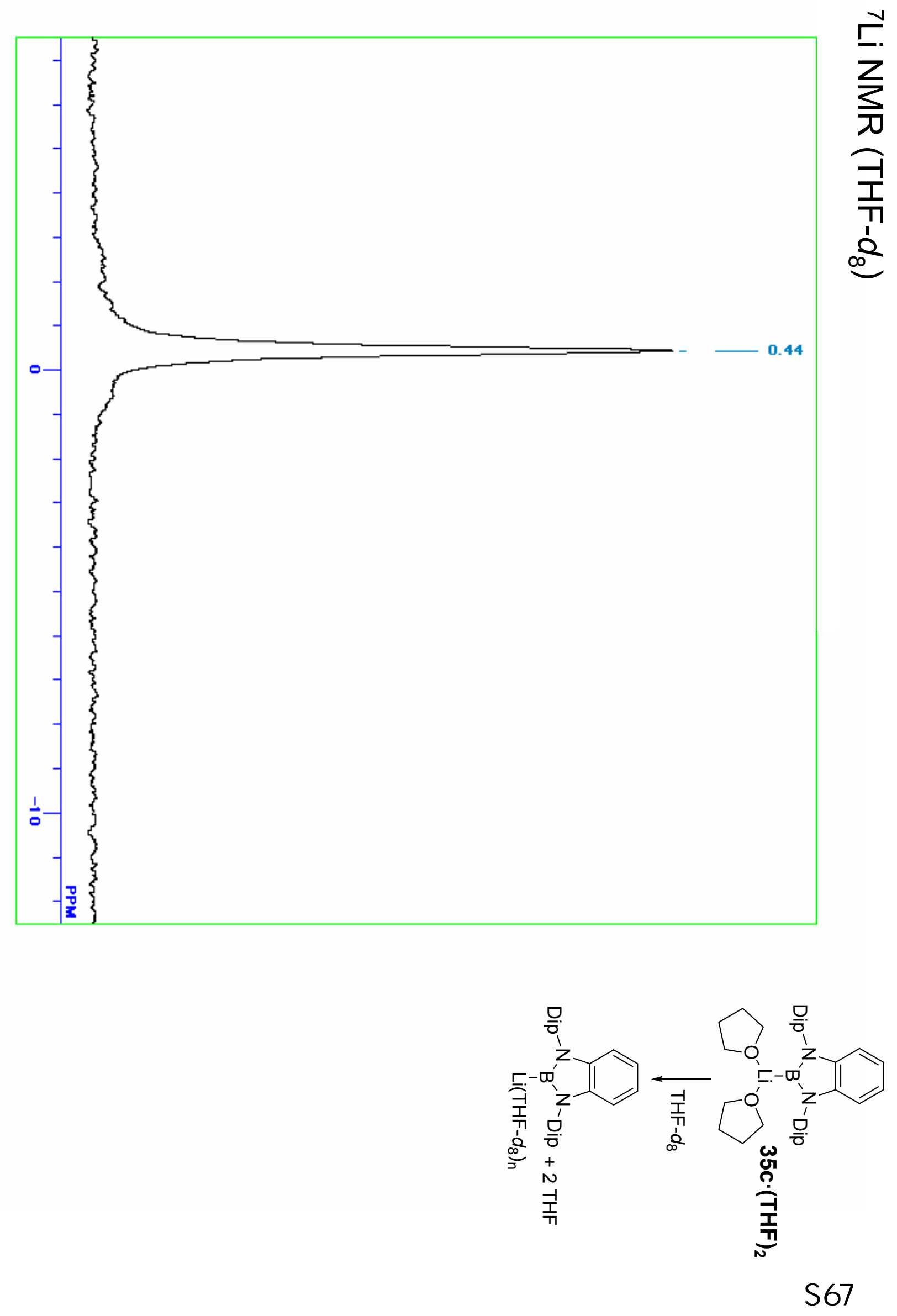




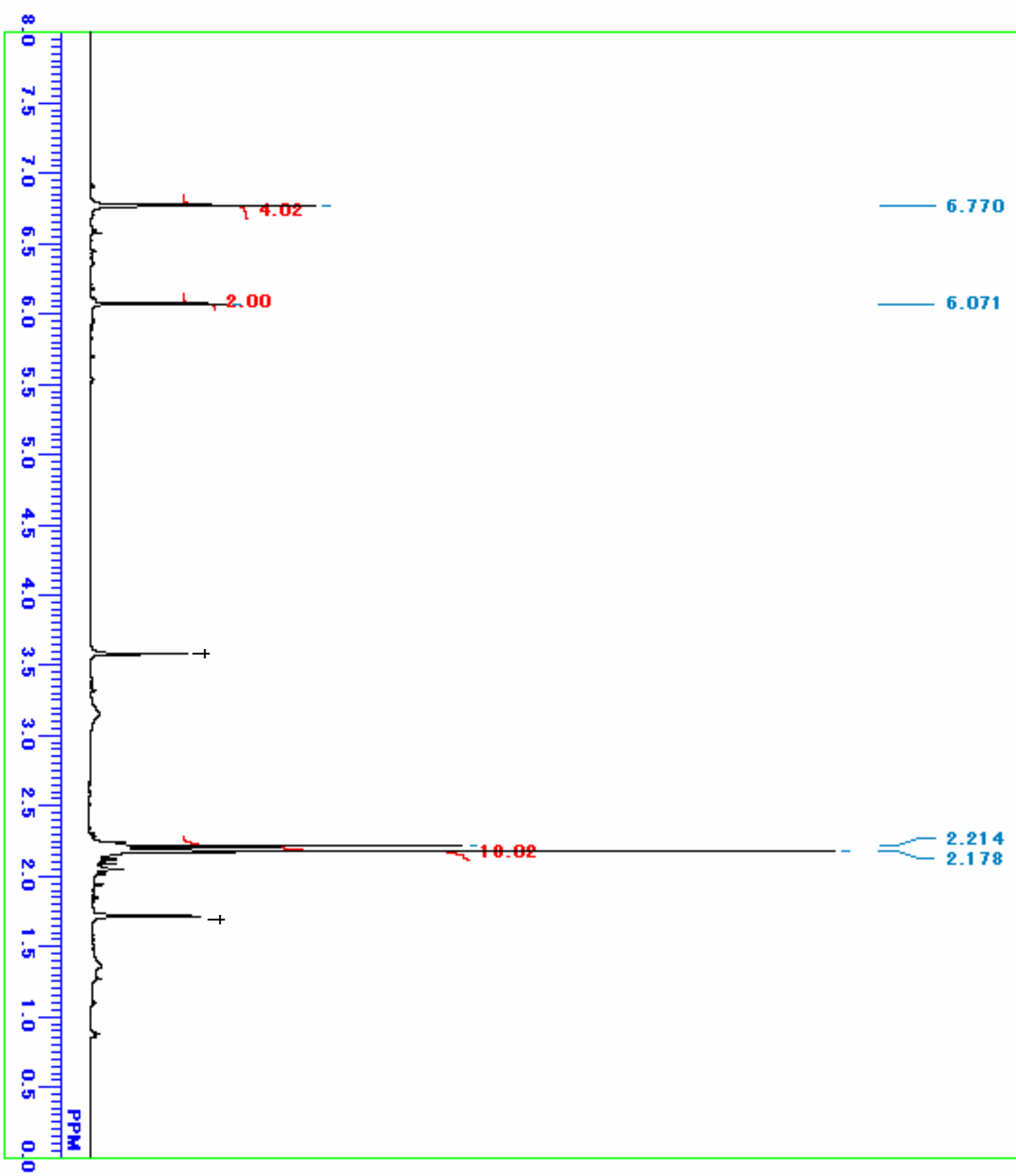

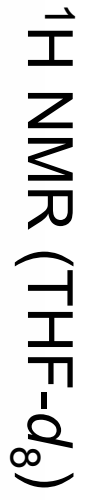

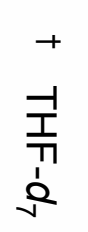

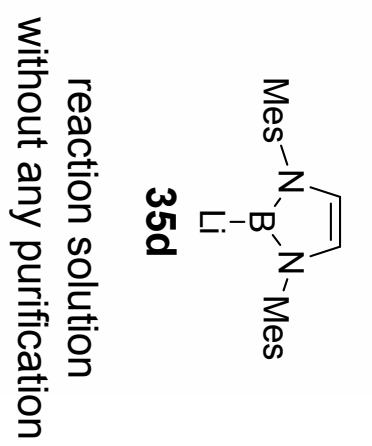




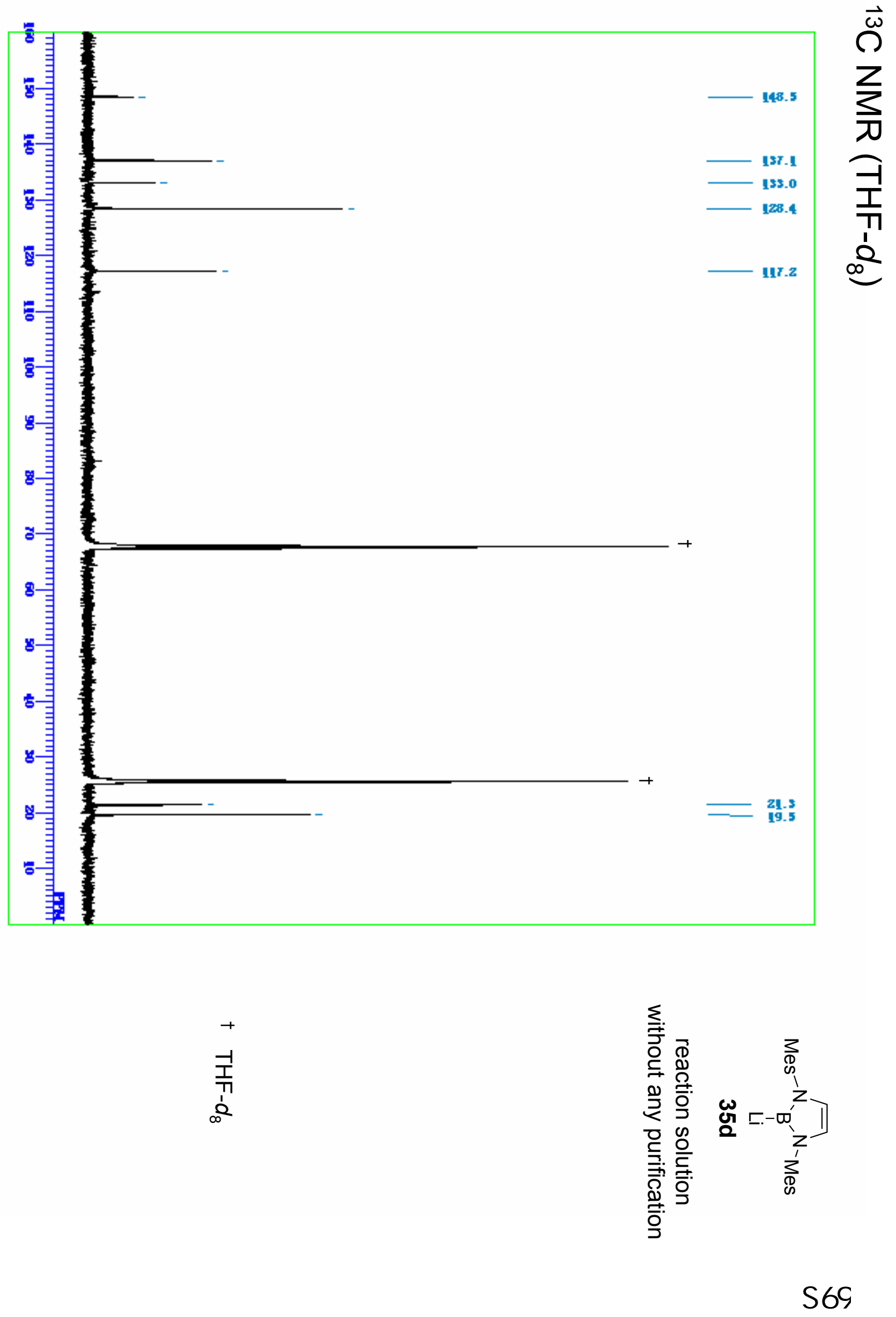




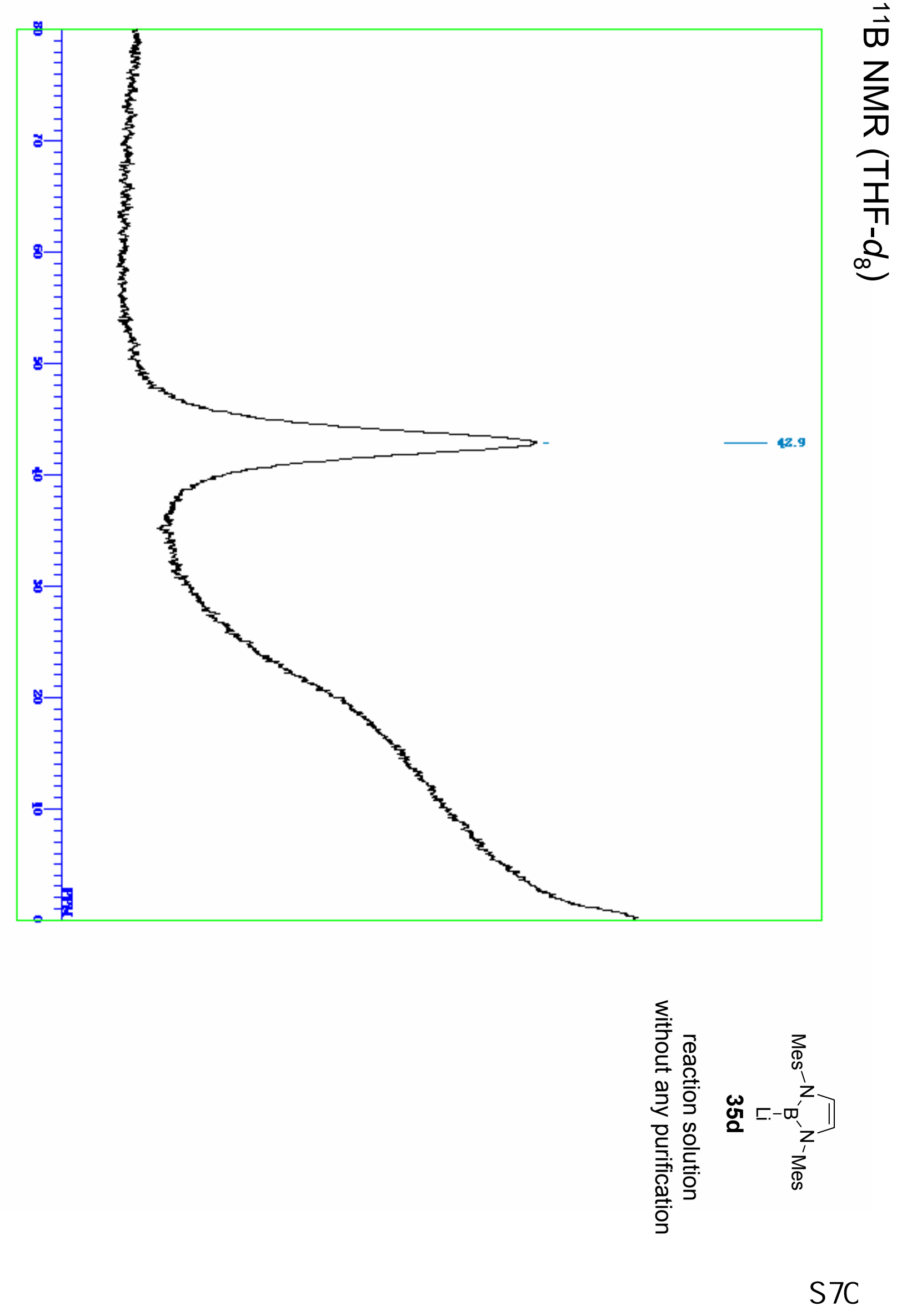




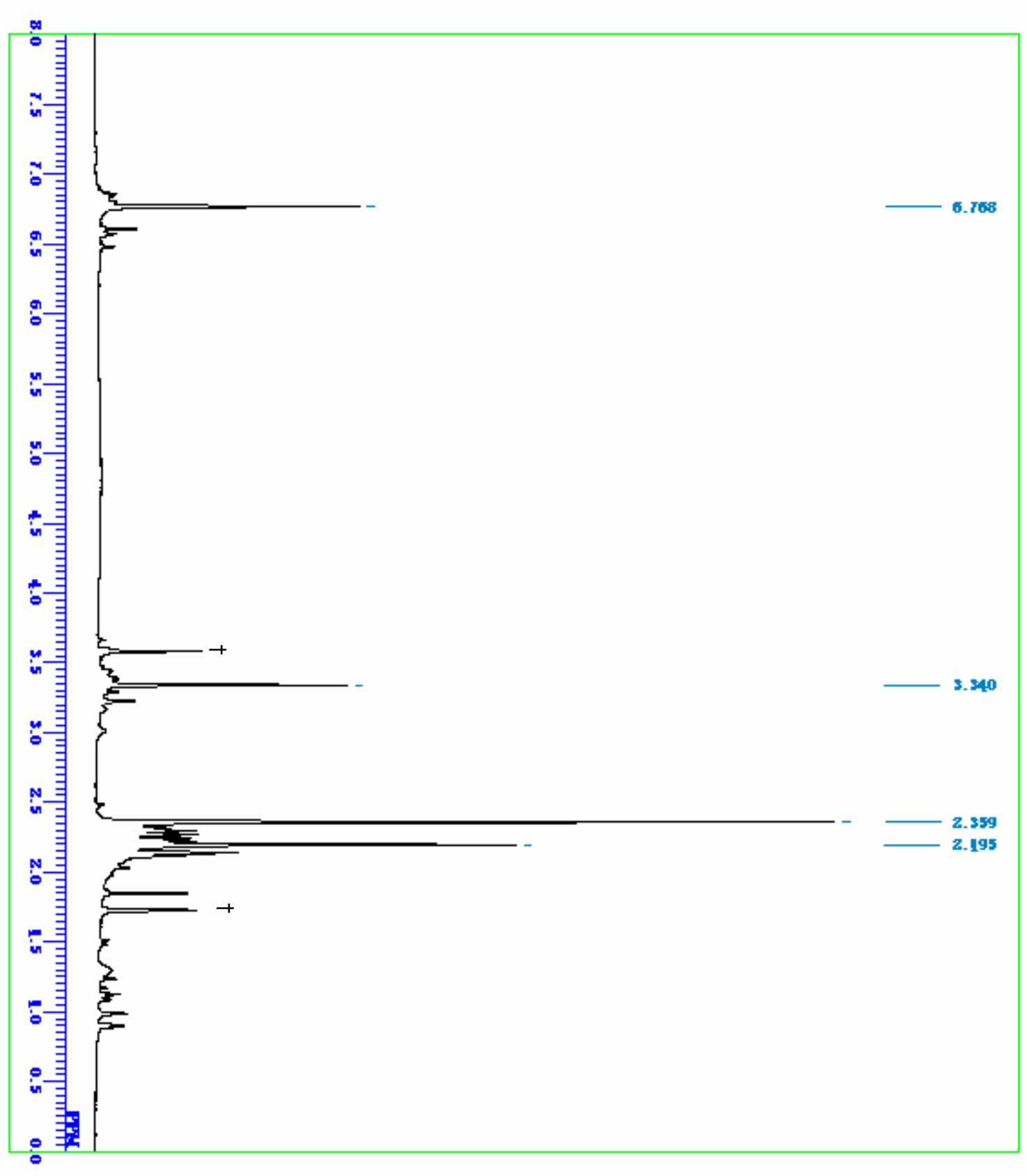

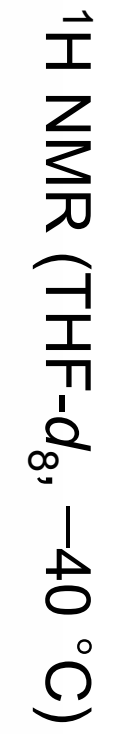

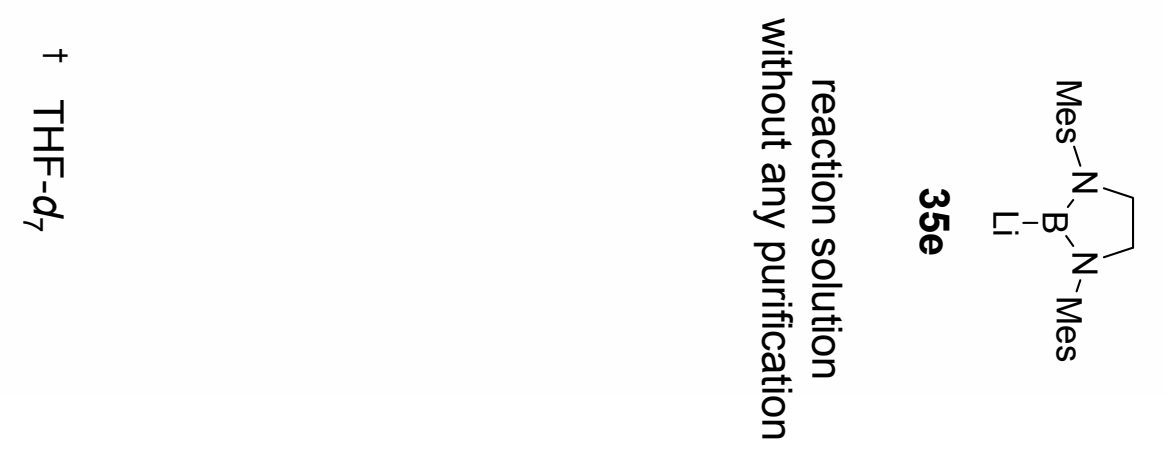

S71 

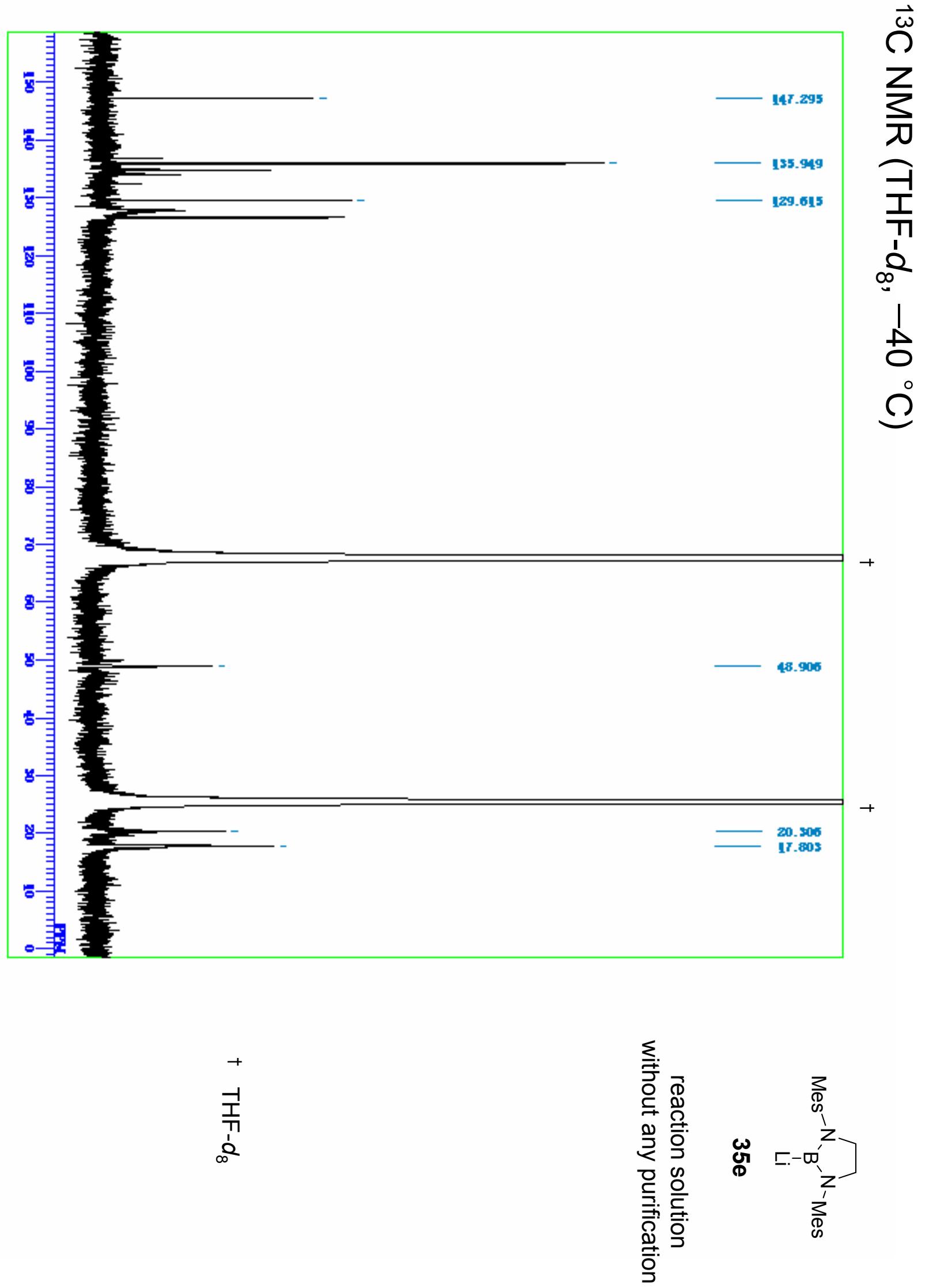


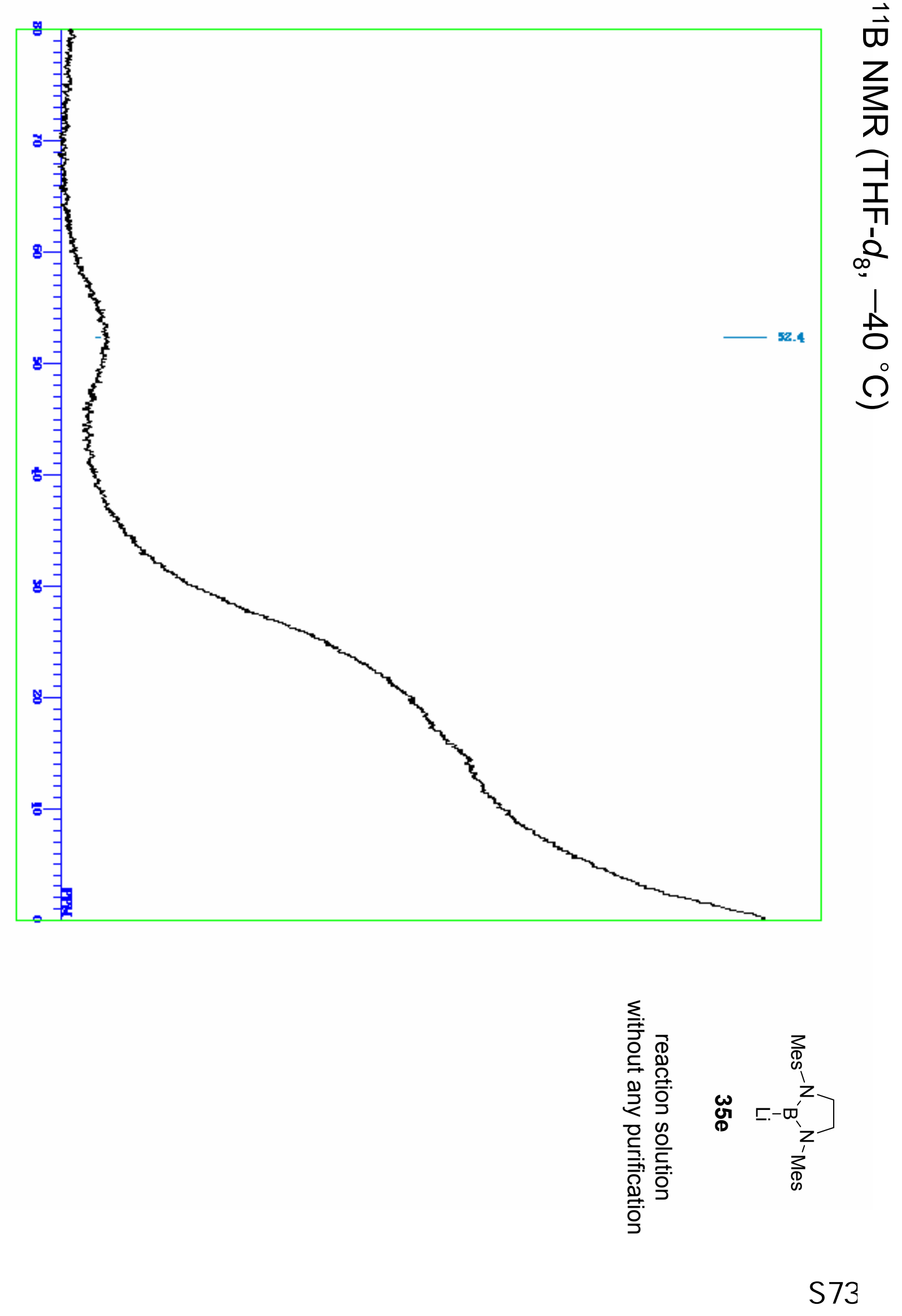



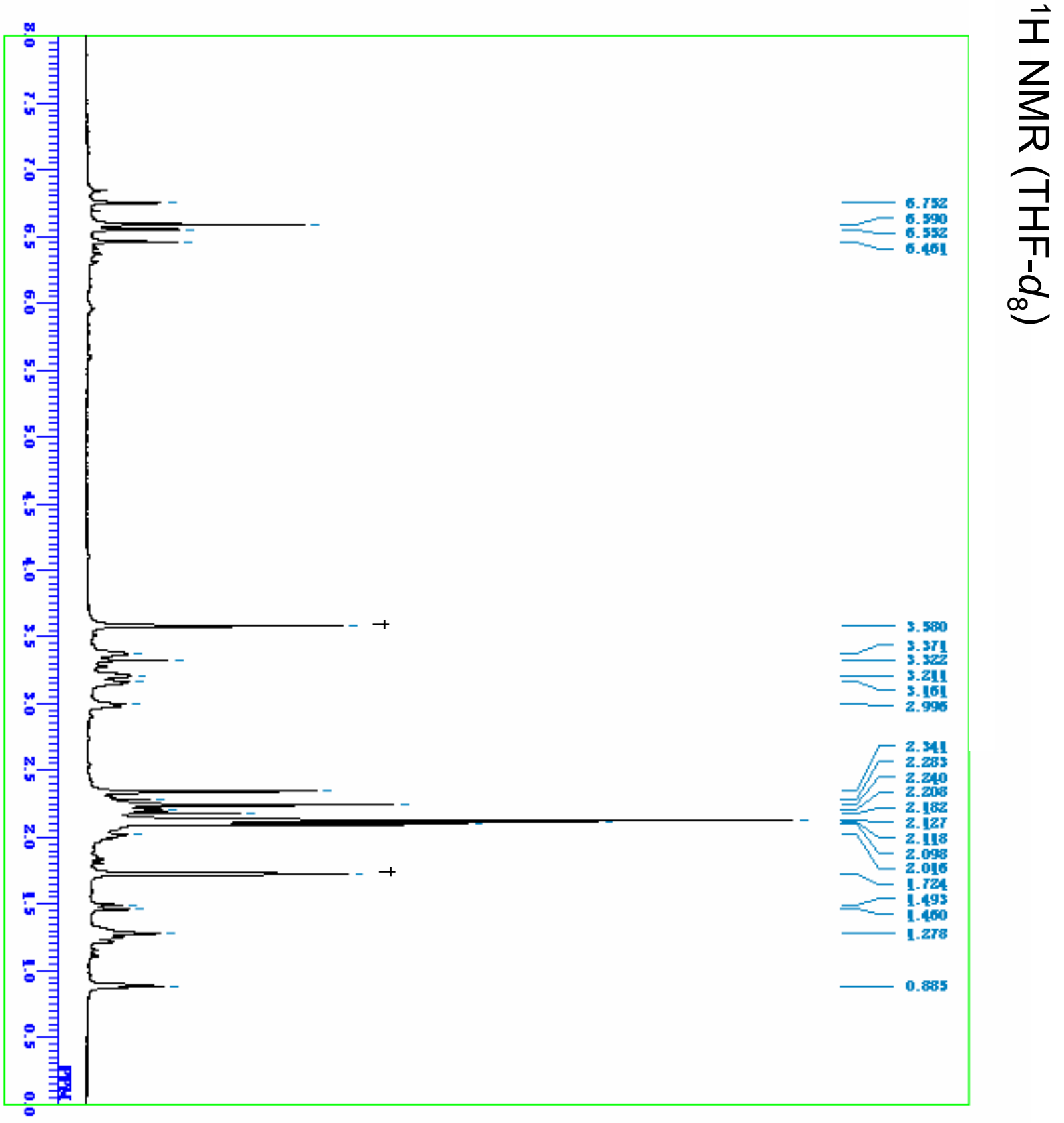

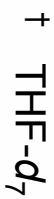

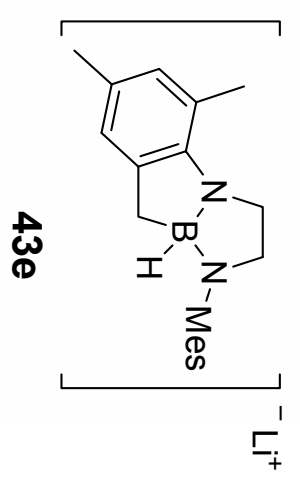




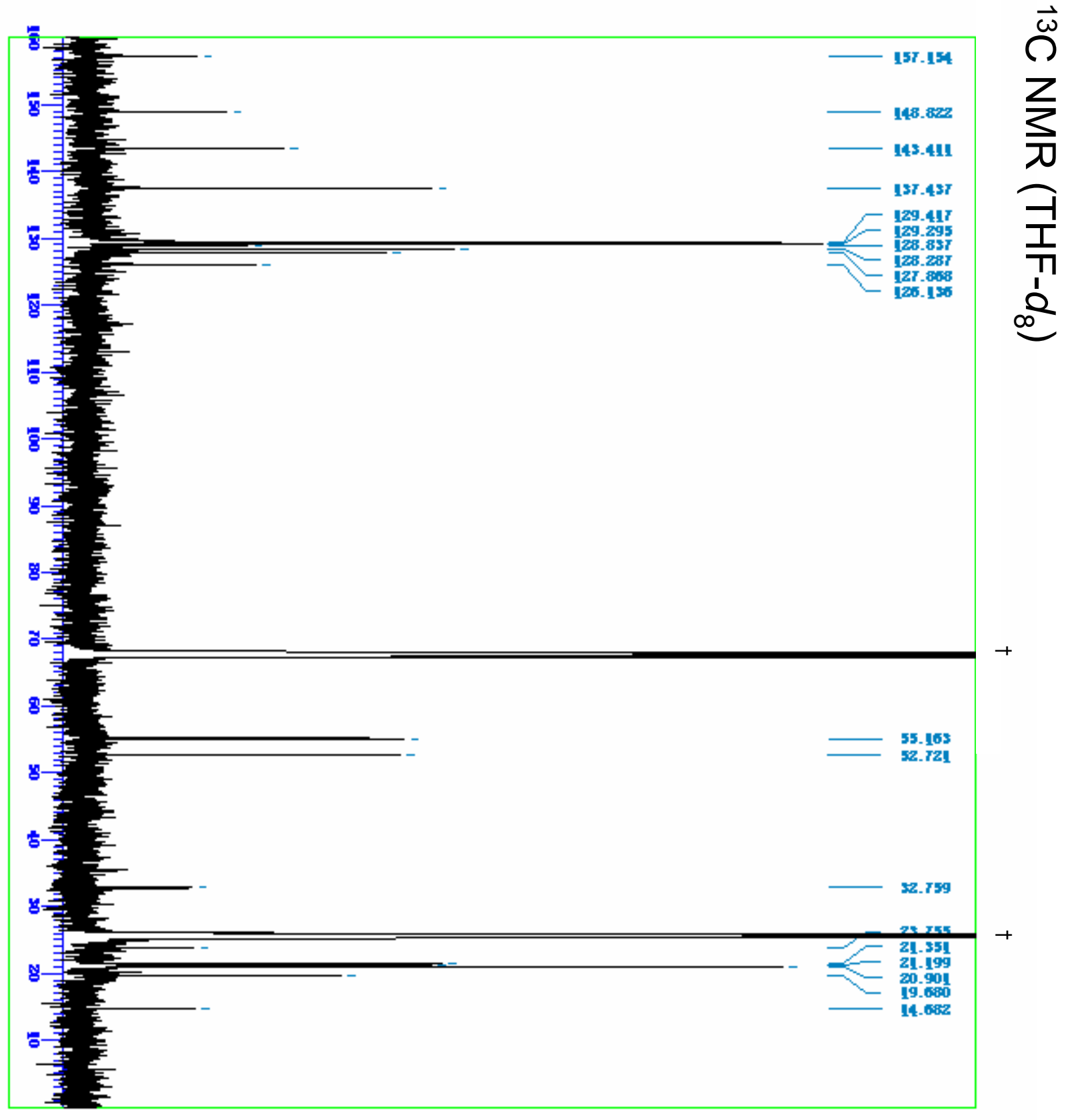

$$
\begin{aligned}
& + \\
& \text { 검 } \\
& \text { T⿱1 } \\
& \operatorname{l}^{2}
\end{aligned}
$$

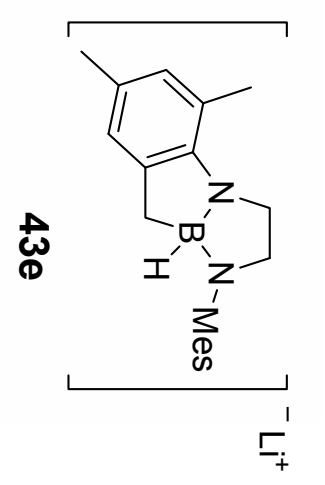




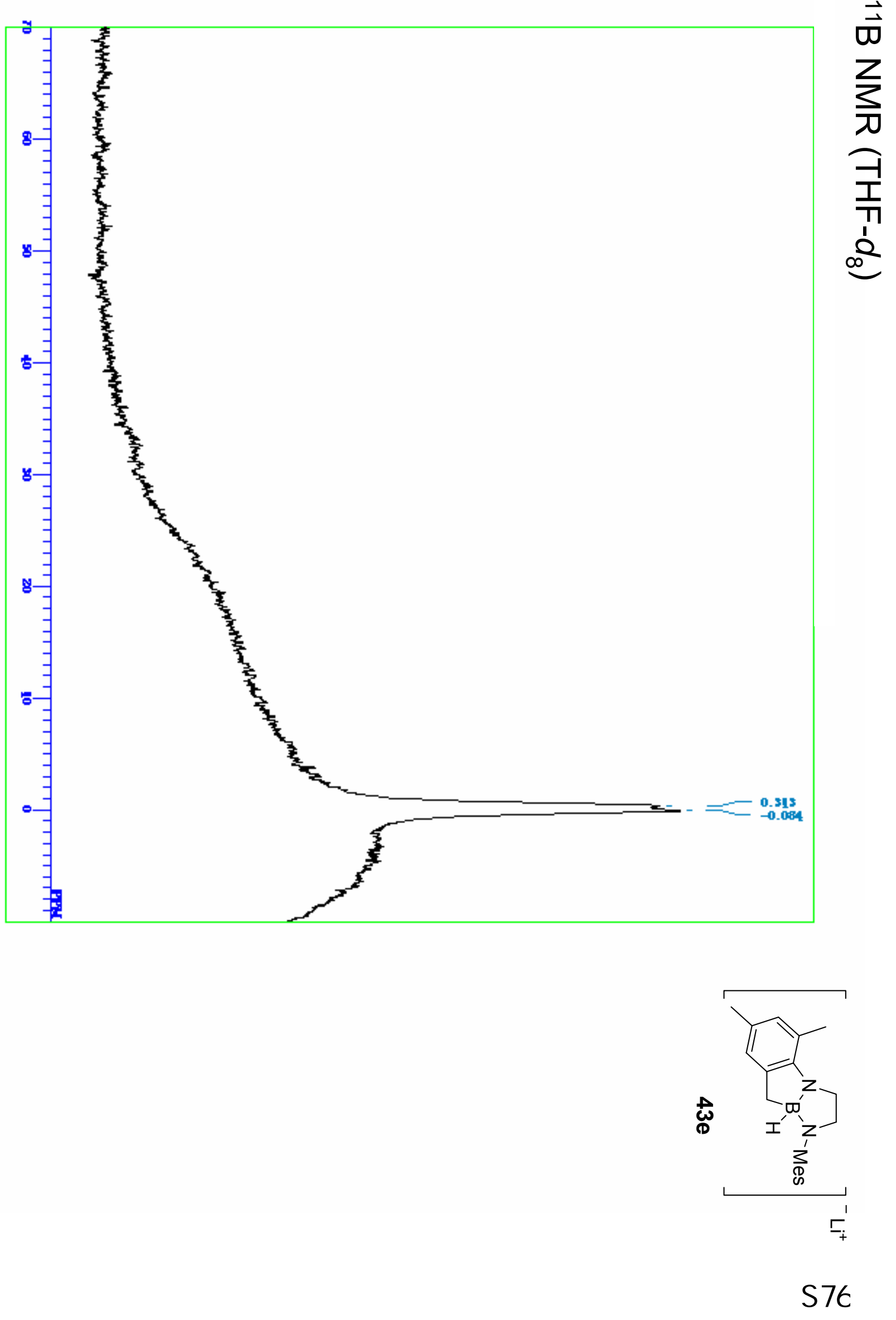




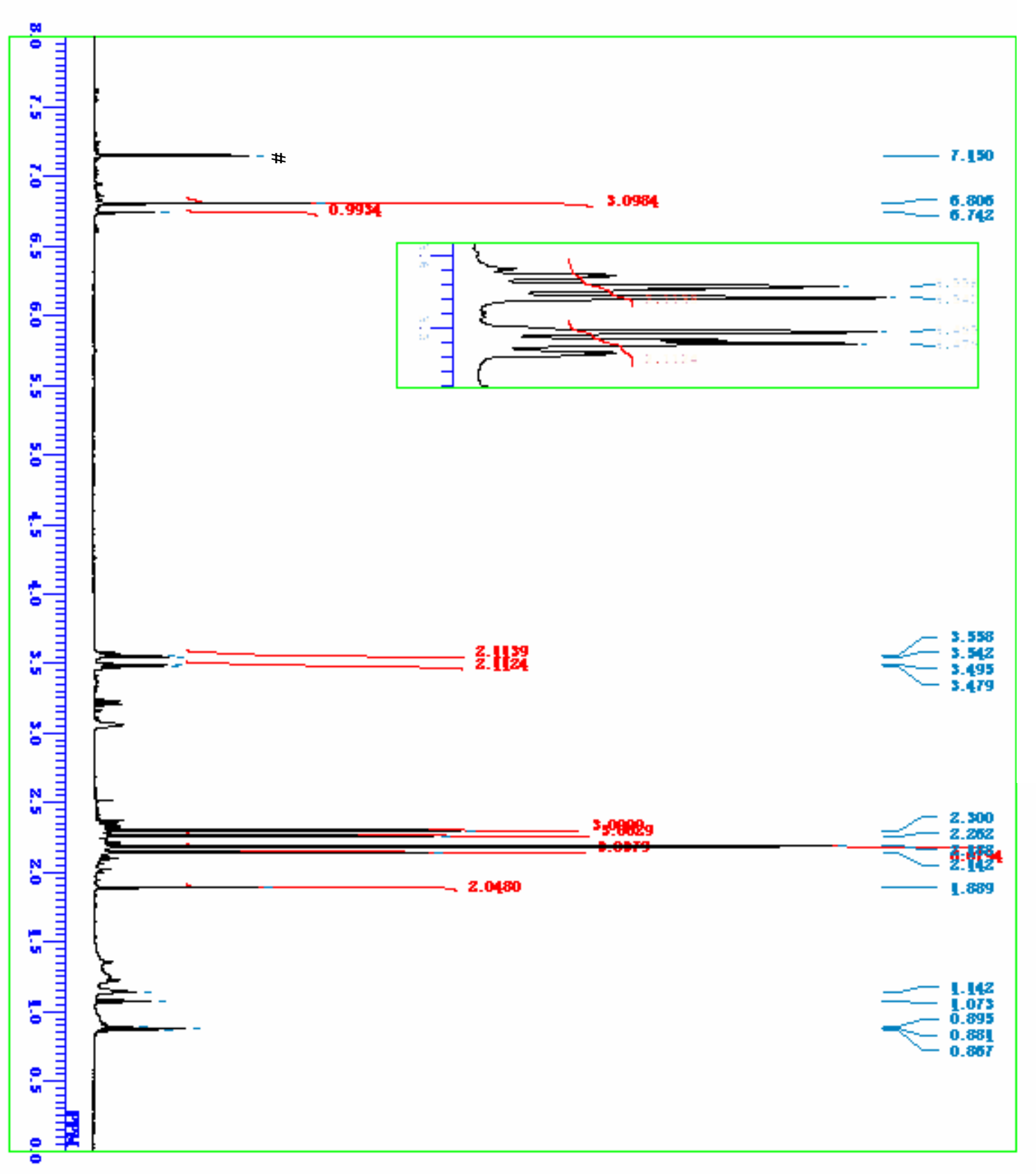

I
$Z$
3
ล
0
0
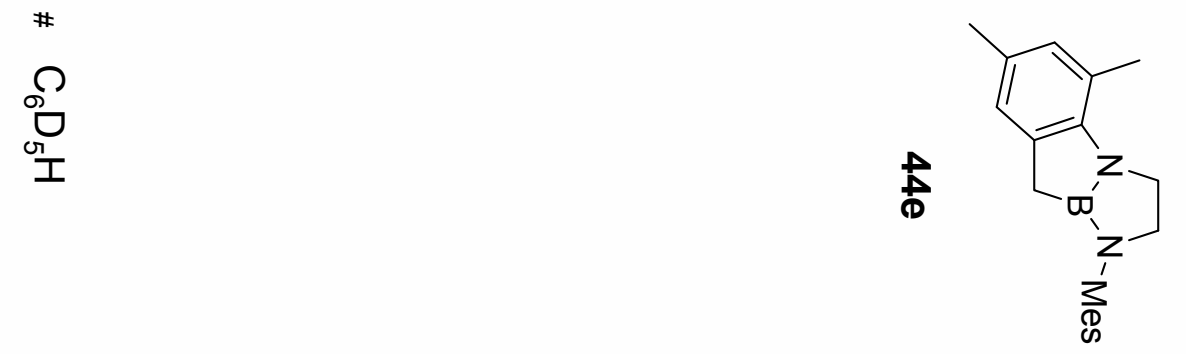


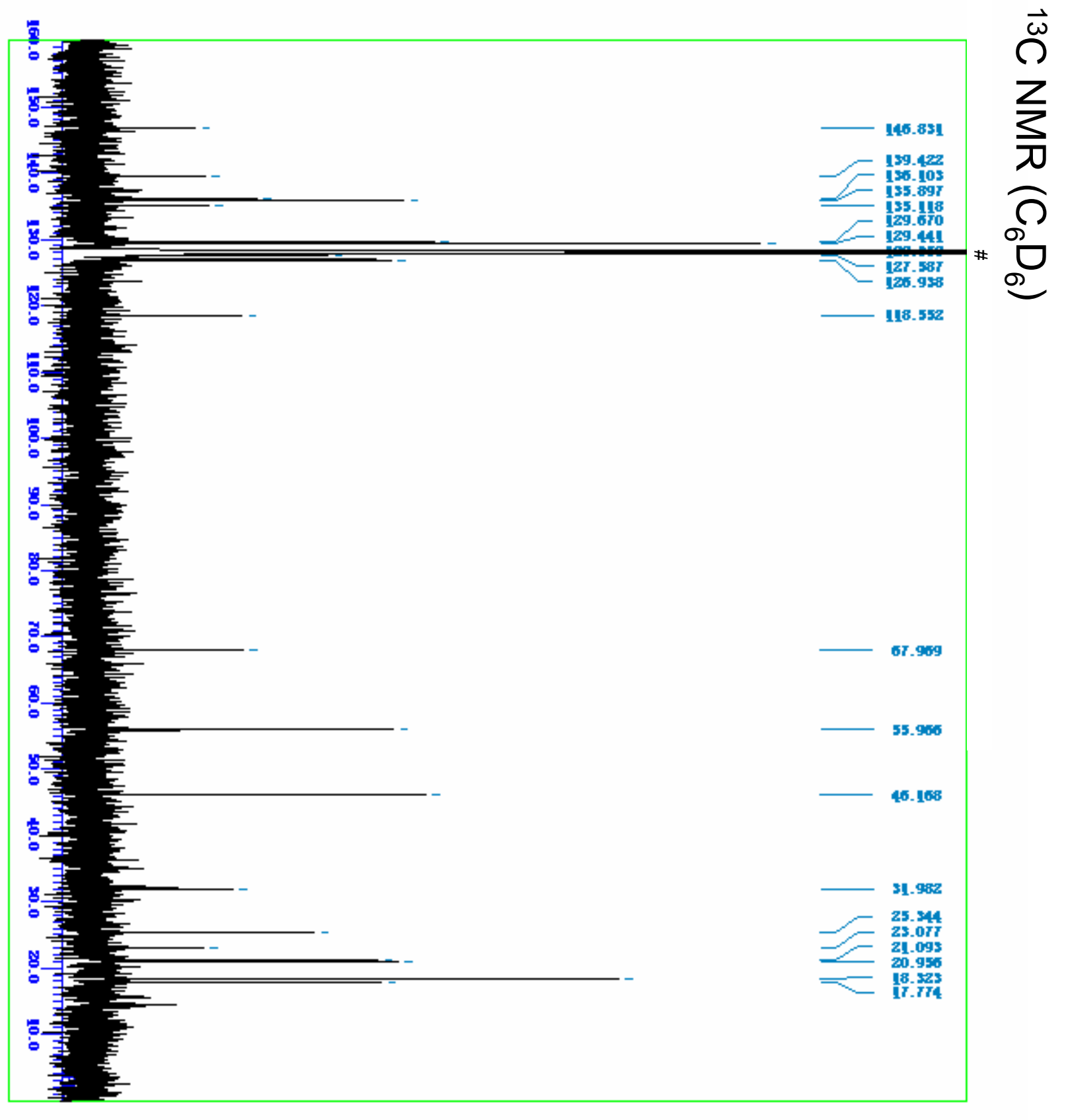

م<smiles>Cc1cc(C)c2c(c1)CO[C]1[C](C=O)CC[Z]12C</smiles> 


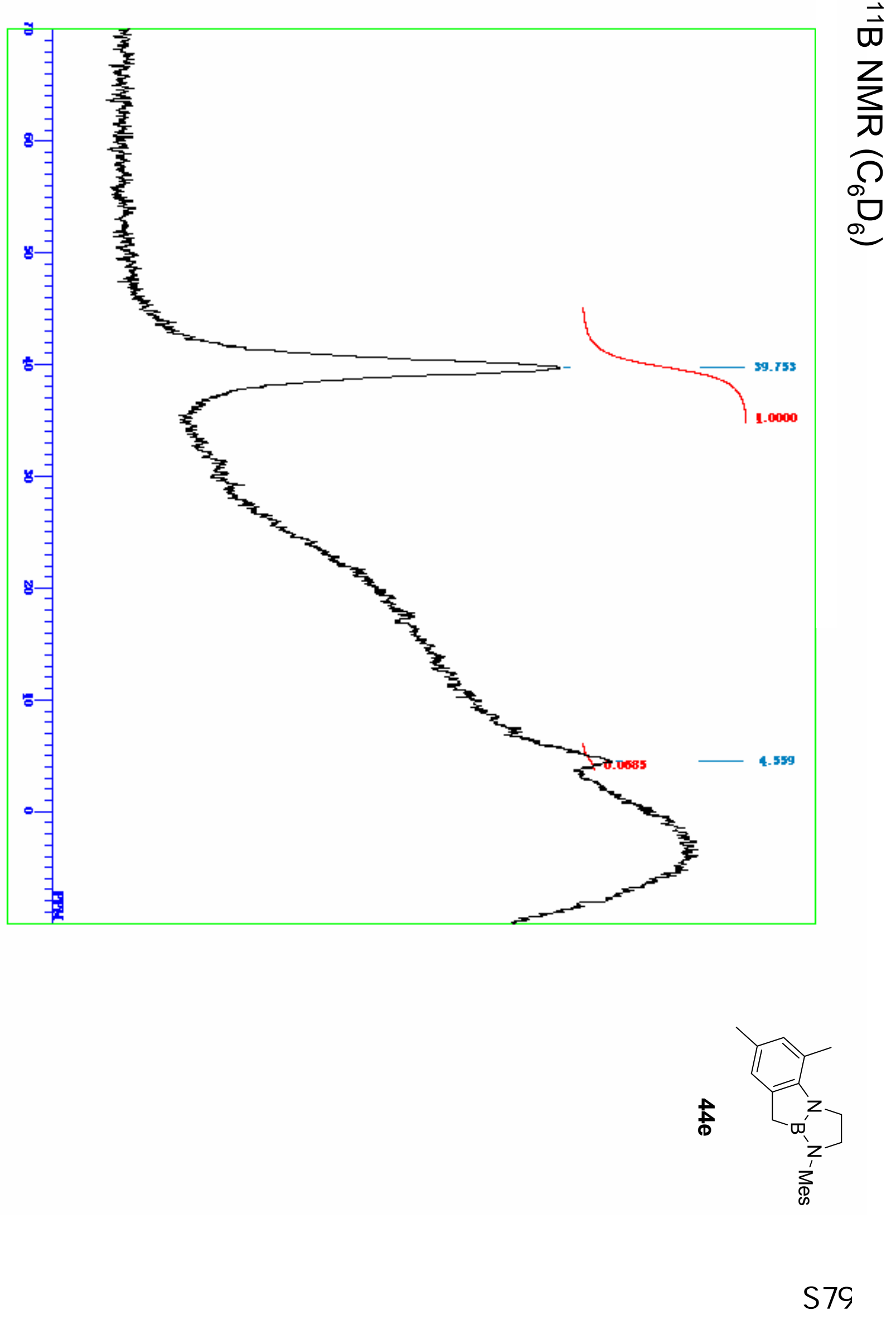

